\title{
Systematics and phylogeny of the Neotropical treehopper subfamily Nicomiinae (Hemiptera, Membracidae)
}

\author{
Jesse L. Albertson \& Christopher H. Dietrich
}

Center for Biodiversity, Illinois Natural History Survey, 607 E. Peabody Dr., Champaign, IL 61820, USA. E-mail:

dietrich@inhs.uiuc.edu

ABSTRACT. Morphological characters of adults of the treehopper subfamily Nicomiinae Haupt, 1929 (Hemiptera, Membracidae) including seven genera (Eudonica gen. nov.; Euwalkeria Goding, 1926; Holdgatiella Evans, 1962; Nicomia Stål, 1858; Nodonica Dietrich, McKamey\& Deitz, 2001; Stalomia gen. nov.; and Tolania Stål, 1858) and 22 species (16 new) are described and illustrated. Keys are provided for genera and for species of Euwalkeria, Holdgatiella, and Nicomia. Nomenclatural changes, based on study of the primary type material of 15 species, include three new combinations, one new synonymy, and reinstatement of one junior synonym. Eudonica has one species, Eudonica nanella sp. nov.; Euwalkeria has five species, including four new species: $E$. colorata sp. nov., E. distincta sp. nov., E. perdita sp. nov., $E$. rubrica sp. nov.; Holdgatiella has two species, one of which is described as new: Holdgatiella chiloensis sp. nov.; Nicomia has twelve species, nine of which are described as new: N. buccina sp. nov, $N$. harenosa sp. nov., N. inscripta sp. nov., N. jucunda sp. nov., $N$. monticola sp. nov., N. nigrifasciata sp. nov., N. notidana sp. nov., N. pulchella sp. nov, N. serrata sp. nov.; Nodonica has one species, Nodonica bispinigera Dietrich, McKamey \& Deitz; and Stalomia has one species, Stalomia veruta sp. nov. Tolania contains eleven previously described species and nearly 60 new species, which will be treated in a later publication. Three new combinations are proposed: one species described in Nicomia is placed in the tribe Abelini (Centrotinae) as Abelus retrospinosus (Lethierry) comb. nov.; one species previously placed in Nicomia is transferred to the genus Tolania as T. obliqua (Walker, 1858), comb. nov.; one species described in Holdgatiella is placed in the genus Tolania as T. stria (Cryan \& Deitz, 2002), comb. nov. One new synonymy is proposed: Hoplophera [sic] cicadoides Walker, 1862, syn. nov., a junior synonym of Nicomia interrupta Stål, 1858. Nicomia subfasciata Stål, 1858, is reinstated. The results of a phylogenetic analysis based on morphology are presented, illustrating the hypothesized relationships among species and genera of Nicomiinae. The analysis supports the broader concept of Nicomiinae proposed here. The monophyly of this group is supported by eleven characters, and all of the included genera are also monophyletic.

KEY WORDS. Distribution, Homoptera, identification, morphology, phylogeny, taxonomy.

RESUMO.Sistemática e filogenia das cigarrinhas neotropicais da subfamília Nicomiinae (Hemiptera,Membracidae). Caracteres morfológicos dos adultos das cigarrinhas da subfamília Nicomiinae Haupt, 1929 incluindo sete gêneros (Eudonica gen. nov; Euwalkeria Goding, 1926; Holdgatiella Evans, 1962; Nicomia Stål, 1858; Nodonica Dietrich, McKamey\& Deitz, 2001; Stalomia gen. nov. e Tolania Stål,1858), e 22 espécies (16 espécies novas) são descritos e ilustrados. Chaves taxônomicas para identificação de gêneros e espécies de Euwalkeria, Holdgatiella e Nicomia são fornecidas. Mudanças nomenclaturais, baseadas no estudo de material-tipo primário de 15 espécies, incluem três combinações novas, uma nova sinonímia e revalidação de um sinônimo-júnior. Eudonica inclui uma espécie nova, Eudonica nanella sp. nov.; Euwalkeria inclui cinco espécies, sendo quatro novas: E. colorata sp. nov., E. distincta sp. nov., E. perdita sp. nov. e E. rubrica sp. nov; Holdgatiella inclui duas espécies, sendo uma nova: Holdgatiella chiloensis sp. nov.; Nicomia inclui 12 espécies, sendo nove novas: N. buccina sp. nov. $N$. harenosa sp. nov, $N$. inscripta sp. nov, $N$. jucunda sp. nov, $N$. monticola sp. nov, $N$. nigrifasciata sp. nov, $N$. notidana sp. nov, $N$. pulchella sp. nov. e N. serrata sp. nov.; Nodonica inclui uma espécie, Nodonica bispinigera Dietrich, McKamey \& Deitz e Stalomia inclui uma espécie nova, Stalomia veruta sp. nov. Tolania inclui 11 espécies previamente descritas e aproximadamente 60 espécies novas, as quais serão tratadas posteriormente em outra publicação. Três combinações novas são propostas: Abelus retrospinosus (Lethierry) comb. nov., previamente em Nicomia, é transferida para a tribo Abelini (Centrotinae); Tolania obliqua (Walker, 1858) comb. nov., previamente em Nicomia; e Tolania stria (Cryan \& Deitz, 2002) comb. nov., previamente em Holdgatiella. Uma nova sinonímia é proposta: Hoplophera [sic] cicadoides Walker, 1862 é considerada um sinônimo junior de Nicomia interrupta Stål, 1858. A espécie Nicomia subfasciata Stål, 1858 é revalidada. Os resultados de uma análise filogenética baseada em caracteres morfológicos são apresentados, ilustrando as possíveis relações entre gêneros e espécies de Nicomiinae. A análise suporta o conceito proposto mais amplo de Nicomiinae. $\mathrm{O}$ monofiletismo da subfamília é suportado por 11 caracteres e todos os gêneros incluídos são também recuperados como monofiléticos.

PALAVRAS CHAVE. Distribuição, filogenia, Homoptera, identificação, morfologia, taxonomia. 
The treehopper family Membracidae Rafinesque, 1815 (Hemiptera, Cicadomorpha), is a group of approximately 3,100 species of sap-sucking insects classified into nine subfamilies (Dietrich et al. 2001, Wallace \& Deitz 2004). The family is distributed worldwide but is most diverse in the New World tropics. Recent phylogenetic analyses (Dietrich et al. 2001, Cryan et al. 2004) indicated that some subfamilies, as currently defined, are para- or polyphyletic and that more detailed analyses of certain lineages are needed. One such lineage includes the subfamily Nicomiinae, a little known group of Neotropical treehoppers previously comprising two genera, Tolania Stål and Nicomia Stål (Dietrich et al. 2001). The group is of considerable interest phylogenetically, because, unlike typical membracids, most nicomiines lack a posterior pronotal process. The characteristic most often associated with the membracids is the presence of an elaborate posterior pronotal process extending over and often concealing the scutellum. However, this characteristic is apparently homoplasious within the Membracidae. The subfamilies Endoiastinae and Nicomiinae, the centrotine genera Abelus Stål and Hemicentrus Melichar, and a few unplaced genera, all lack this posterior process. Endoiastinae, the sister group to the remaining membracids, apparently arose prior to the initial acquisition of a posterior pronotal process. Morphological evidence (Dietrich \& Deitz 1993, Dietrich et al. 2001) indicates that Nicomiinae are derived from treehoppers with the posterior process well developed. In particular, some nicomiine species retain the notch or groove in the scutellum in which the posterior process of other membracids rests. In addition, in Euwalkeria Goding, the posterior process is present in one species but absent in others and the posterior process is fully developed and conceals the scutellum in the genus Nodonica Dietrich, McKamey \& Deitz. Although biologists have long been puzzled by the adaptive significance of the membracid pronotum, it is especially difficult to explain why the posterior process was gained only to be lost in Nicomiinae and a few genera in other treehopper lineages.

The purpose of this work is to clarify the limits and phylogenetic status of Nicomiinae and revise the generic and specific level classification based on adult morphology. The study includes diagnoses and descriptions of species, including numerous new species: four new species of Euwalkeria, one Holdgatiella Evans, eight Nicomia, and two new genera.

The taxonomic placements of genera treated here have been unstable for more than a century (summarized in Tab. I). STÅL (1858) described the genus Tolania to include those species of Membracidae that lack a posterior pronotal process but have suprahumeral horns on the pronotum. In the same paper he described the genus Nicomia to include species without a posterior pronotal process, a convex and unarmed thorax, and a scutellum with the apex truncate or rounded. He placed these two genera in the subdivision Centrotida, which comprised species of the currently recognized subfamilies Centrotinae and Stegaspidinae. Goding (1892) provided a key to the Centrotinae
(Membracidae), placing Tolania in the Aethalionini [sic]. Goding (1926b) placed these two genera in the Aethalioninae [sic], then treated as a subfamily of Membracidae, based on the absence of a posterior pronotal process. A key to species of Tolania and Nicomia was published by Goding (1927). In his catalogue, FunKHOUSER (1927) placed Nicomia in the subfamily Centrotinae (Membracidae) without comment and considered Aethalionidae [sic] as a separate family.

HAUPT (1929) erected the subfamily Nicomiinae, classified within Aetalionidae, for species with the frontoclypeus concave and the head wider than the pronotum, including only the type genus, Nicomia. He also placed Tolania in its own subfamily, Tolaniinae, within Membracidae, based on wing venation, presence of suprahumeral horns, and the shape of the scutellum. Goding (1930) included Tolaniini as a tribe of Aethalioninae [sic] (Membracidae) including the genus Tolania. Goding (1931a, 1934) later expanded the Tolaniini to include Old World genera such as Porcorhinus Goding (now placed in Cicadellidae, Ledrinae) and Hemicentrus Melichar (now placed in Membracidae, Centrotinae). FunkHouser (1943) listed Tolania as a member of the Centrotinae. Evans (1946) placed Nicomia in the Membracidae, although he considered the genus to be more closely related to Aetalion than other membracids. Evans (1948) elevated the Nicomiinae to family status, Nicomiidae, redescribing the family based on Nicomia cicadoides (Walker) and including the genera Tolania and Nicomia, based primarily on the following similarities: pronotum without posterior process and with hind margin transverse, scutellum completely exposed, and veins $\mathrm{M}_{3}$ and $\mathrm{M}_{4}$ separated in the forewing. FunKHOUSER (1951) placed Tolania (containing 10 species) and Nicomia (six species) in Centrotinae, tribe Abelini. Metcalf \& Wade (1965) placed Nicomia in Nicomiidae and, apparently misinterpreting HAUPT's (1929) classification, placed Tolania in Aetalionidae. They included Nicomia and other genera now placed in the family Aetalionidae (Lophyraspis Stål, Gerridius Fowler, Mina Walker) and the membracid subfamily Endoiastinae (Endoiastus Fowler), and Paroristes Johnson \& Fox (nomen nudum) in the family Nicomiidae. Hamilton (1971) suggested that, although Nicomia lacks a posterior pronotal process, it is a "true" membracid and that Tolania is "probably" a member of the membracid subfamily Nicomiinae. Deitz (1975) classified Tolania and Nicomia in the family Nicomiidae. Based on a phylogenetic analysis of morphological characters, Deitz \& Dietrich (1993) returned Nicomiinae, including only Nicomia and Tolania to Membracidae.

Goding (1926a) described Euwalkeria based on Aethalion [sic] latipes Walker, placing it in the membracid subfamily Centrotinae based on the presence of a posterior pronotal process that did not completely conceal the scutellum. Goding (1928) provided a key to Centrotinae and included Euwalkeria in the tribe Acuminatini. FunKHouser (1951) placed Euwalkeria in Aethalionidae [sic]. НаміLтоN (1971) considered Euwalkeria to be closely related to the cicadellid genus Coloborrhis (Ulopinae) based on characters of the head and forewing, while 


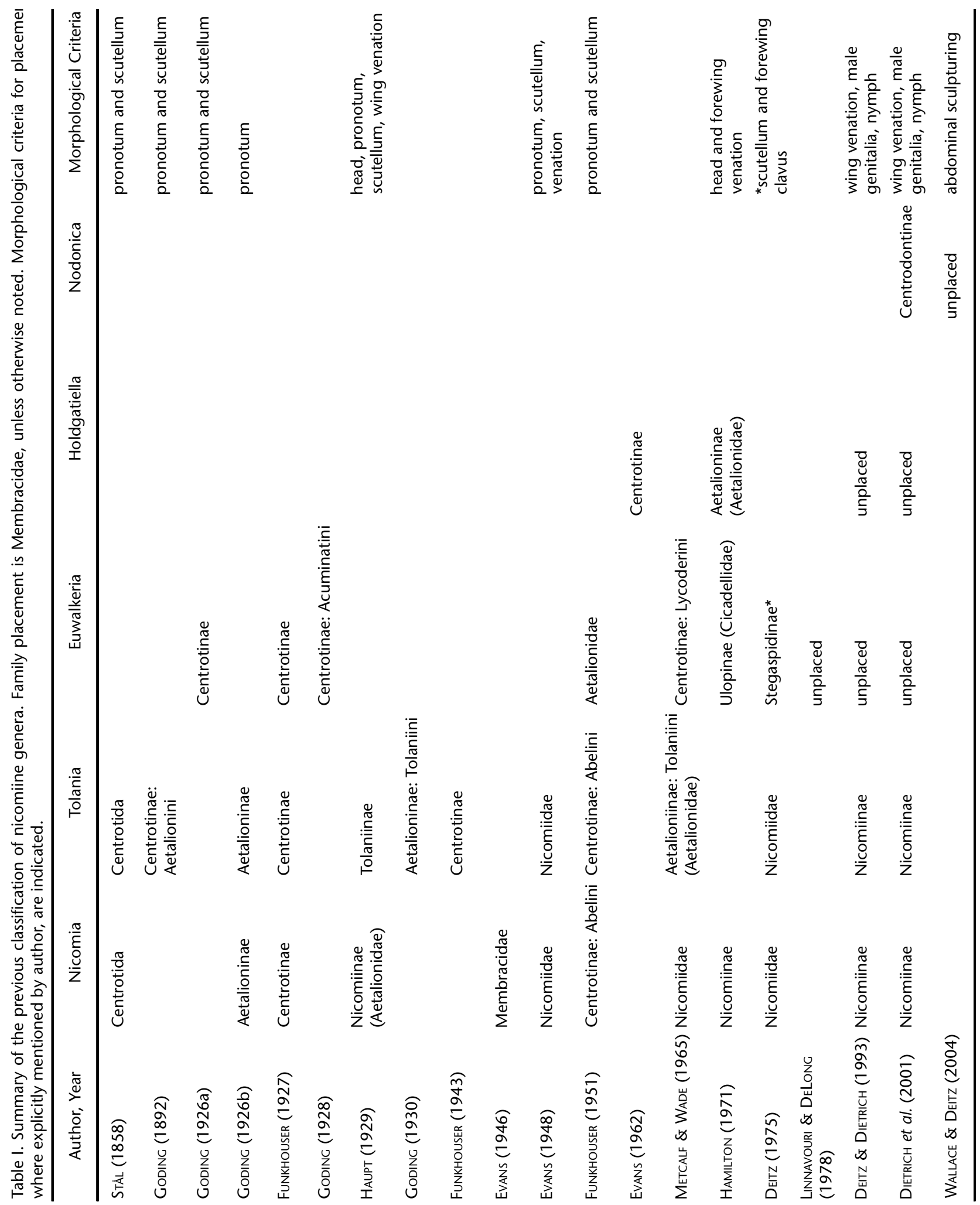


noting that "it alone in this family [Cicadellidae] has a pronotal process." Deitz (1975) placed this genus in Stegaspidini (as "Stegaspini").

Evans (1962) described Holdgatiella (including only $H$. chepuensis) in the subfamily Centrotinae. He also transferred Holdgatiella to Aetalioninae (Aetalionidae). Deitz (1975) excluded Holdgatiella from Membracidae. Linnavouri \& DeLong (1978) included Holdgatiella in Membracidae, unplaced to subfamily, and more recent authors have maintained its status as incertae sedis within Membracidae.

Euwalkeria, Holdgatiella, and three additional genera (Antillotolania Ramos, Deiroderes Ramos, and Togotolania Cryan \& Deitz) appear to be related to Nicomiinae because they lack a posterior pronotal process (the process is present or absent in Euwalkeria) and have the width of the head greater than the distance across the pronotal humeri. The morphology-based phylogeny of Dietrich et al. (2001) grouped these genera (Togotolania Cryan \& Deitz listed as "New Genus T") in a clade with Nicomiinae, Stegaspidinae, Centronodinae, and Centrodontinae, but relationships among these taxa were poorly resolved. Subsequent, more detailed morphology-based analyses of Stegaspidinae placed Antillotolania + Deiroderes as sister to a clade comprising two undescribed Dominican amber species and the extant members of Stegaspidini and Microcentrini, but the position of Togotolania remained unresolved (CRYAN et al. 2003). A detailed morphology-based analysis of Centrotinae (WALlace \& Deitz 2004) supported placement of Centrodontini (excluding Nodonica) as a tribe of Centrotinae. This placement, and the placement of Antillotolania and Deiroderes in Stegaspidinae, are consistent with the results of analysis of DNA sequence data, but such data have so far only been obtained for a single nicomiine species (Lin et al. 2004). Immediately prior to the present study, Euwalkeria, Holdgatiella, Nodonica, and Togotolania remained unplaced to subfamily. The first three of these genera are here included in Nicomiinae based on cladistic analysis of morphological characters (see Cladistic Analysis below). We were unable to study specimens of Togotolania.

The distribution of the Nicomiinae is entirely Neotropical. Tolania is the most widely distributed of the seven genera, occurring as far north as Mexico's Yucatan Peninsula, throughout Central America, and south to Argentina (McKamey 1998). Nicomia has been collected in South America and Panama. Euwalkeria is known from Brazil and Colombia, Eudonica, new genus, and Nodonica from Ecuador, and Holdgatiella only from Chile. Stalomia, new genus, has been collected only in French Guiana. The South American distribution, with a only a few species in Central America and Mexico, is evidence these groups appeared during the time (ca. 100 to 6 m.y. BP) when South America was isolated from the other continents (Dietrich \& DeITz 1993).

Little is known about the ecology of Nicomiinae. Antattended and gregarious species are common in both Aetalionidae and Membracidae and this seems to be the plesiomorphic condition for these two families (DIETRICH et al. 2001, CRYAN et al. 2004). Nicomiines are collected rarely, usually only as single individuals (WOOD 1984), suggesting that these species, unlike many membracids, are solitary as adults. Tolania apparently lack parental care (DieTRICH et al. 2001), another common behavior in Membracidae. The nymphs are known only for Tolania and Nodonica (Dietrich et al. 2001). Tolania nymphs are unusual in being relatively active in comparison to most membracid nymphs. Tolania nymphs (Fig. 10) have been observed running along the branches of their host plants with the tips of their abdomens held erect (Dietrich, unpublished).

\section{MATERIAL AND METHODS}

Pinned specimens were borrowed from museum and personal collections in the United States, Europe, and Latin America. More than 1,000 specimens were examined, including twelve Euwalkeria, seven Holdgatiella, 29 Nicomia, three Nodonica, two Eudonica, one Stalomia, and the remaining specimens Tolania. Primary types were examined for all previously described species, except Holdgatiella chepuensis Evans; those described by Germar, which are apparently lost; Tolania armata Goding (based on illustrations by STOLL 1788) and T. walkeri Goding. The following abbreviations are used to refer to the collections from which specimens were borrowed or have been deposited: BMNH - The Natural History Museum, Cromwell Road, London, SW7 5BD, UK (M. D. Webb); CAS - California Academy of Sciences, Golden Gate Park, San Francisco, California 94118, USA (N. D. Penny); GMNH - Georgia Museum of Natural History, University of Georgia, Athens, Georgia 30602, USA (C. Smith); INHS - Illinois Natural History Survey, 607 E. Peabody Dr., Natural Resources Building, Champaign, Illinois 61820, USA (C. Favret); INPA - Instituto Nacional de Pesquisas da Amazônia, Alameda Cosme Ferreira, 1756, Manaus, Amazonas, Brazil (A.L. Henriques); MLUH - Martin-LutherUniversität, WB Zoologie, Domplatz 4, 4020 Halle, Germany (M. Dorn); MNHN - Museum National d'Histoire Naturelle, 45 rue de Buffon, 75005 Paris, France (M. Boulard); NCSU North Carolina State University Insect Collection, Department of Entomology, North Carolina State University, Raleigh, North Carolina 27695-7613, USA (R. L. Blinn); NRS - Naturhistorisches Riksmuseet, SE-104 05, Stockholm, Sweden (B. Viklund); SHMC - S.H. McKamey Collection; current address: Systematic Entomology Laboratory, USDA, c/o National Museum of Natural History, Smithsonian Institution, Washington, D.C. 20560, USA; UCB - Essig Museum of Entomology, University of California, Berkeley, California 94720, USA (C. B. Barr); UFPC Universidade Federal do Paraná, Departamento de Zoologia, C.P. 19020, 81531-980 Curitiba, Paraná, Brazil (A. M. Sakakibara); UKY - Department of Entomology, Agricultural Science Center North, University of Kentucky, Lexington, Kentucky 40546, USA (P.H. Freytag); USNM - National Museum of Natural History, Smithsonian Institution, Washington, D.C. 20560, USA (D. G. Furth, S.H. McKamey). 
Observations of specimens were made using a dissecting microscope at 8 to $100 \mathrm{x}$ magnification under incandescent light. Photographs were taken using a Q-Imaging Micropublisher digital camera mounted on a dissecting microscope.

Structures of the genitalia were observed after clearing and dissection. The abdomen was first removed from the dry specimen by inserting a pin ventrally between the thorax and the base of the abdomen and gently breaking the abdomen away. The abdomen was then soaked in a potassium hydroxide $(10 \%$ $\mathrm{KOH})$ solution for 24 hours or until the cuticle was transparent and resilient. The $\mathrm{KOH}$ solution was rinsed away two to three times with distilled water and the abdomen was stored in glycerin. Chaetotaxy and other characteristics of the leg were more easily observed using the described clearing method.

Only critical synonymies are included in this paper. Complete listings of synonymies can be found in the catalogues of FunKhouser (1927), Metcalf \& WAde (1965), and McKamey (1998).

Measurements were made using an ocular micrometer on a dissecting microscope. The measurements are in millimeters and include observed ranges for each sex. Body length is the distance from the anterior margin of the compound eye to the apex of the forewing in lateral view. The head width is the maximum distance between the lateral margins of the compound eyes. The pronotal width is the distance between the apices of the humeral angles. The width across the tips of the suprahumeral horns, where applicable, is in dorsal view and measures the distance between the apices of the suprahumeral horns. The forewing length is the distance from the base of the forewing to its apex.

Labels of primary type material examined are quoted using a virgule (/) to indicate line breaks of a label and a semicolon (;) between information on separate labels. Most of the holotypes designated are males, except in three species where only females were available.

Distributions of species were based only on specimen labels. Records from the literature were not included unless they could be verified through examination of specimens.

Unless otherwise noted in the treatments of species, the nymphs and host plants are unknown. Host plant records for Tolania are based on label data and WOoD (1984).

For convenience, genera and species are listed in alphabetical order rather than based on hypothesized phylogenetic relationships. All taxa treated here are considered to belong to the nominotypical tribe, Nicomiini.

New names and other nomenclatural acts should be attributed only to the first author.

\section{RESULTS AND DISCUSSION}

\section{Morphology}

The most useful characters at the species level included aspects of the aedeagus, male pygofer, forewing venation, cucullate setal rows on meso- and metathoracic tibiae, and char- acters of the pronotum. The terminology used follows that of Deitz (1975), Dietrich \& Deitz (1993), and Dietrich et al. (2001).

Coloration of the head, pronotum, and forewing appears to be reliable for diagnosing some species but not others. Individuals of many species of Nicomia and Tolania are very similar in coloration whereas other species within the two genera are polymorphic in color pattern. Males and females of a species were difficult to associate in some cases due to color polymorphism, especially in Nicomia and Euwalkeria.

The frontoclypeus varies in shape from ventrally flattened or concave in Nicomia (Fig. 7), Stalomia (Fig. 129), and Euwalkeria (Fig. 9); produced ventrally but not convex in Eudonica (Fig. 20), Holdgatiella (Fig. 47), and Nodonica; to produced ventrally and convex in Tolania (Fig. 8). Several Tolania species possess a median longitudinal carina or a transverse fold of the frontoclypeus. The vertex varies in proportions, in the placement and development of dorsal processes, in the shape of the ventral margin, and in the development of the bases of the ocelli. The coloration of the vertex and its punctures are diagnostic in some species but exhibit considerable intraspecific variation in others.

The most obvious character of the pronotum is the absence (Euwalkeria, Eudonica, Stalomia, Holdgatiella, Nicomia, Nodonica, and some Tolania) or presence of suprahumeral horns (Fig. 8). These horns are polymorphic within some Tolania species. Those possessing horns often display a wide range of horn lengths, shape, orientation, and horns may even be absent in some individuals. Some species of Tolania also possess a short dorsal median pronotal tubercle, although this is highly polymorphic. The medial carina of the pronotum varies among genera and to some extent within Tolania. The extent of pubescence can vary from dense to sparse to nearly glabrous.

The exposed scutellum of Nicomiinae offers a number of characters. The shape of the scutellum base may be flat, slightly inflated, or acutely produced dorsally, as seen in a few species of Tolania. One species of Nicomia has a scutellar keel. The apex of the scutellum often displays a groove that can be distinct or absent, or the apex may have a faint longitudinal carina. Also useful, although varying continuously within Tolania, is the shape of the scutellum apex (rounded/truncate, narrow/acute, or emarginate).

The forewing venation is among the most useful features for recognizing genera of Nicomiinae, especially the number of branches of veins $\mathrm{R}$ and $\mathrm{M}$ as well as the number and placement of crossveins. In some Tolania species, the number of crossveins may vary among individuals or even between the two forewings of an individual. Nevertheless, within Tolania, the venation is useful for separating species into groups. The location of crossvein $\mathrm{m}-\mathrm{cu}$ in relation to the fork of $\mathrm{M}_{3+4}$ is a valuable character. The presence and location of maculae on the forewing is also useful. The forewing clavus varies from bluntly rounded (Nicomia) to sharply acuminate distally (Holdgatiella). The hindwing varies in the vestiture of the api- 
cal membrane (arcuate chaetoids in Holdgatiella (Fig. 4A) and microtrichia in the remaining genera (Fig. 2A)) and the location of crossvein m-cu.

The shape of the pro- and mesothoracic legs varies from foliaceous in Euwalkeria (Fig. 13), Eudonica, and Nodonica to slender and bicarinate in the remaining Nicomiinae genera. The number of cucullate setal rows on the metathoracic tibiae is usually stable within genera, with Nicomia, Nodonica, and Eudonica having two rows, and Tolania, Stalomia, and Holdgatiella having three rows. Most Euwalkeria have two rows, but some males have a third weakly developed row. Cucullate setal rows on the mesothoracic tibiae are found only in Tolania and vary at the specific level from absent to one or two longitudinal rows. Nicomia have two to four large spines on the metathoracic trochanter (Fig. 12) and these vary somewhat in shape and size among species.

The shape of the abdomen is most easily distinguished in males after clearing. Nicomia males have the abdomen in dorsal view ovoid in shape between segments III-VII (Fig. 15) and the pygofer retracted into the pregenital segment. Holdgatiella (Fig. 16), Euwalkeria, Nodonica, Eudonica, and Tolania abdomens are evenly tapered posteriorly; but some Tolania species have the lateral margins roundly tapered between segments III-VII and segments VIII and IX attenuate.

The male genital capsule (including the pygofer, lateral plates, and subgenital plate) varies greatly between Nicomia and Tolania and among species. The paired lobes of the subgenital plate are fused to various degrees. Among species of Nicomia and Tolania, the lobes have two distinct forms, the first being entirely sclerotized and the second being with only the outer margins sclerotized. The lobe may also exhibit a pronounced medial fold and may have distinct processes at the corners of this fold. The lateral plates vary in length, shape, orientation, and the presence or absence of extra processes.

The male and female genitalia of Nicomiinae have not been surveyed extensively in previous studies. Traditionally, the taxonomy was based on pronotal shape, color pattern, and wing venation. Recent studies (Dietrich \& Deitz 1991, McKamey \& Deitz 1991) have shown that features of the genitalia are useful for distinguishing species and in phylogenetic analysis of some membracid groups. Unlike in many groups of membracids, the aedeagus of Nicomiinae is highly variable among species and is, thus, the most useful diagnostic character.

The aedeagus in Nicomiinae is usually L-shaped, with the apex directed posterodorsally, but some included taxa (e.g., Nodonica) have the aedeagus U-shaped, with the apex directed dorsally (Fig. 17), as in most other membracids. The shape and orientation of the styles are distinctive in some species but the styles of many species are nearly identical. Scale-like texture and different kinds of setae are also observed on the styles of some species.

Nicomia females exhibit remarkable intraspecific variation in genitalia structure compared to that found in other membra- cid genera. Species in this genus differ in the shape of the pygofer and dorsal dentition of the second valvulae. In contrast, Tolania females are not easily identified, because the valvulae and pygofer are nearly identical among all species examined.

\section{Nicomiinae Haupt, 1929}

Nicomiinae Haupt, 1929: 237.

Tolaniinae Haupt, 1929: 228.

Diagnosis. Head width, including compound eyes, equal to or greater than distance between humeral angles of pronotum (except in Nodonica). Pronotum posterior process absent (exceptions: Euwalkeria latipes with posterior process concealing scutellum dorsomedially and Nodonica with posterior process completely concealing scutellum). Forewing vein $\mathrm{R}$ initial division $\mathrm{R}_{1+2+3}$ and $\mathrm{R}_{4+5}$; vein $\mathrm{R}$ with 4 or more branches (except some Holdgatiella with $3 \mathrm{R}$ branches); vein $\mathrm{M}$ with 3 or more branches reaching apex of wing. Hindwing apical membrane with microtrichia (except Holdgatiella with arcuate chaetoids). Hindwing crossvein m-cu distinctly basad of $\mathrm{M}_{3+4}$, apex of cell truncate (except Holdgatiella with crossvein m-cu subparallel to $\mathrm{M}_{3+4}$ before angle and apex of cell acute). Male abdominal segments evenly tapered in dorsal view (exceptions: Nicomia with segments III-VIII ovoid, and some species of Tolania with lateral margins roundly tapered between segments III-VII and segments VIII and IX attenuate). Aedeagus usually L-shaped in lateral view, with apex directed posteriorly (except Nodonica with aedeagus U-shaped).

Distribution. Central and South America, ranging from southern Mexico south to Central Chile.

\section{Key to the genera of Nicomiinae}

1. Forewing with 2 m-cu crossveins (Fig. 4); hindwing apex with arcuate chaetoids (Fig. 4A) ............ Holdgatiella Evans

$1^{\prime}$. Forewing with $1 \mathrm{~m}$-cu crossvein or venation reticulate; hindwing apex glabrous or with microtrichia (Fig. 2A) . 2

2. Forewing with supranumerary crossveins (reticulate, Fig. 5); pro- and mesothoracic tibiae foliaceous (Fig. 13); pronotum without posterolateral projections, posterior process present or absent

\section{3}

2 '. Forewing with 1 or $2 \mathrm{r}-\mathrm{m}$ and 1 or $2 \mathrm{~m}$-cu crossveins, or, if venation reticulate, then with the following combination of characters: tibiae slender and bicarinate (Fig. 12); pronotum with posterolateral projections developed (Fig. 6), posterior process absent.

3. Posterior pronotal process present, completely concealing scutellum (Fig. 11); width of head less than distance between pronotal humeral angles; aedeagus U-shaped (Fig. 17) .......................... Nodonica Dietrich, McKamey\& Deitz

3'. Posterior pronotal process absent, or, if present, not concealing scutellum; width of head greater than distance between pronotal humeral angles (Fig. 6); aedeagus usually L-shaped ..................................................................... 4 
4. Frontoclypeus convex but not produced ventrally, with transverse carina or fold (Fig. 20)

Eudonica Albertson, gen. nov.

4'. Frontoclypeus flattened ventrally, without transverse carina or fold (Fig. 9) .....................................Euwalkeria Goding

5. Forewing with $2 \mathrm{r}-\mathrm{m}$ crossveins, $\mathrm{r}-\mathrm{m}_{1}$ basad of $\mathrm{R}_{1}$ and perpendicular to veins $\mathrm{R}$ and $\mathrm{M}$ (Figs 1 and 3); suprahumeral horns absent ... 6

5'. Forewing with $1 \mathrm{r}-\mathrm{m}$ crossvein (Fig. 2), if $2 \mathrm{r}-\mathrm{m}$ crossveins present then $\mathrm{r}-\mathrm{m}_{1}$ either distad of $\mathrm{R}_{1}$ or not perpendicular to veins $\mathrm{R}$ and $\mathrm{M}$; suprahumeral horns present (Fig. 8) or absent Tolania Stål

6. Forewing with 1-2 crossveins connecting branches of M (Fig. 3, m); frontoclypeus convex ventrally (Fig. 129); metathoracic tibia cucullate setal rows I, II, and III present; furcasternum reduced, without lobes; metepimeron concealed by forewing at rest; metathoracic trochanter unarmed .......................... Stalomia Albertson, gen. nov.

6'. Forewing without crossvein connecting branches of M (Fig. 1); frontoclypeus flattened ventrally (Fig. 7); metathoracic tibia cucullate setal rows II and III present; furcasternum lobed (Fig. 78); metepimeron exposed by forewing at rest; metathoracic trochanter with 2 or more spines (Fig. 12) .

Nicomia Stål

\section{Eudonica Albertson, gen. nov.}

Type species. Eudonica nanella Albertson, sp. nov.

Diagnosis. Eudonica differs from other Nicomiinae in having the following combination of features: frontoclypeus convex but not produced ventrally with a transverse carina or fold; posterior pronotal process absent; forewing with supranumerary crossveins; pro- and mesothoracic tibiae foliaceous.

Description. Head (Fig. 20). Vertex width between eyes more than 2x height of vertex; dorsal processes short, broad, closer to eyes than to midline; ocelli not elevated; ventrolateral margins carinate. Frontoclypeus convex but not produced ventrally, transverse carina or fold present. Thorax. Distance from eye to wing base more than half eye width. Pronotum (Figs 18-20) punctation dense; dorsal pubescence short; median carina strongly keeled, especially posteriorly; dorsal postocular keel absent; ventral postocular keel well developed, posteroventral margin of postocular keel acute; suprahumeral horns present as small tubercles; posterior margin evenly rounded, posterolateral projections absent. Scutellum (Figs 1819) base flat or slightly inflated; apex short, punctures and setae absent, emarginate, medial groove distinct. Forewing (Fig. 5) venation reticulate; clavus apex acuminate; first and second anal veins confluent for short distance distally, second anal vein well developed. Metepimeron concealed by forewing at rest. Legs: pro- and mesothoracic tibiae foliaceous; mesothoracic femur with cucullate setae absent, tibia with cucullate setal rows absent; metathoracic femur with distal pair of cu- cullate setae dorsally, tibia with cucullate setal rows II and III present. Furcasternum reduced, without lobes. Male. Sternite VI slightly wider than sternites VII and VIII; sternite VII length less than or equal to width; sternite VIII width more than $2 \mathrm{x}$ length. Lateral plate more than half length of subgenital plate; sternite IX emarginate anteromedially; subgenital plate lobes incompletely fused, uniformly sclerotized without distinct fenestrae. Aedeagus (Figs 23-24) posterior arm straight; shaft tubular. Female. Unknown.

Distribution. Ecuador: Azuay.

Notes. The name Eudonica (feminine) combines parts of the names of two related genera this new genus most closely resembles: Euwalkeria and Nodonica.

\section{Eudonica nanella Albertson, sp. nov. Figs 5, 18-24}

Type locality. Challuabamba, 11 rd km NE Cuenca, Azuay, Ecuador [SHMC].

Diagnosis. This species is distinguished in having lateral plates broad in dorsal view and sinuate in lateral view and the aedeagus shaft tubular with a single pair of apical processes.

Description. Male. Color. Vertex dark orange; red-orange maculae mesad of ocellus and surrounding ocellus; dorsolateral corner and lateral margin black; ventral margin pale; frontoclypeus red-orange; gena black. Pronotum dark yellow to yellow-orange, red-orange laterally, punctures dark orange; black maculae forming 3 or more arcs across metopidium; black medial macula posteriorly; scutellum base orange with redbrown longitudinal maculae and margins; apex pale yellow; ventral thorax black. Forewing basal sclerotization brown on corium, yellow-orange with dark punctures on clavus; membrane hyaline; veins pale yellow. Legs: femora red-brown to black with yellow base and apex; tibiae dark yellow with redbrown base and transverse maculae; tarsomere I red-brown, tarsomeres II and III yellow with red-brown lateral margins. Head. Vertex with short, pale setae; dorsomedial surface distinctly concave. Thorax. Pronotum metopidium high, nearly vertical (Fig. 18); posterior process absent. Metathoracic tibia with cucullate setal row II present and row III restricted to distal half. Abdomen. Lateral plate broad in dorsal view (Fig. 22) and sinuate in lateral view (Fig. 21); subgenital plates with subbasal constriction, apical two-thirds with lateral margins parallel. Aedeagus (Figs 23-24) apex narrow with a single pair of processes; gonopore on ventral preapical surface. Connective (Fig. 24) anterior margin strongly emarginate, apices diverging; posterior apex broadly rounded. Style shank (Fig. 23) straight preapically in lateral view; apex bent and blade-like.

Female. Unknown.

Measurements (mm). Male. Body length 5.1-5.2; head width 1.9; pronotal width 1.9; forewing length 4.4-4.5.

Material examined. Holotype male: "S.H. McKamey lot/ \#86-0102-2; ECUADOR: Azuay/ Challuabamba,/ 11 rd km NE; Cuenca. 2400m/ 2 Jan 1986/ McKamey, Coll.; Deitz Research/

Revista Brasileira de Zoologia 22 (1): 231-283, março 2005 
9-1-130c ơ; Albertson Research/ EUW-0125 ơ; Holotype/ Eudonica/ nanella/ Albertson" [SHMC]. Paratype male, same data (Albertson Research EUW-0127 male) [SHMC].

Distribution. Ecuador: Azuay. Collection date: January.

Note. The specific name 'nanella' translates from Latin as "little dwarf", referring to the species' small size.

\section{Euwalkeria Goding, 1926}

Euwalkeria Goding, 1926a: 104.

Type species: Aethalion [sic] latipes Goding, 1926, by original designation.

Diagnosis. Euwalkeria differs from other Nicomiinae in having the following combination of features: frontoclypeus flattened, without transverse fold; posterior pronotal process absent or present; forewing with supranumerary crossveins; pro- and mesothoracic tibiae foliaceous.

Description. Head. Vertex width between eyes more than $2 \mathrm{x}$ height of vertex (Fig. 9); with short, pale setae; dorsal processes short, broad, closer to eyes than to midline; ocelli not elevated; ventrolateral margins carinate. Frontoclypeus flattened; transverse carina or fold absent. Thorax. Distance from eye to wing base more than half eye width (Fig. 25). Pronotum punctation dense (Fig. 26); dorsal pubescence short; median carina strongly keeled, especially posteriorly; dorsal and ventral postocular keels well developed; suprahumeral horns weakly developed, apparently represented by small tubercles; posterior margin evenly rounded (except E. latipes angulate laterally), posterolateral projections absent; posterior process absent or present (E. latipes) with scutellum exposed. Scutellum base flat or slightly inflated; apex short, punctures and setae absent, emarginate, medial groove distinct (Fig. 26). Forewing venation reticulate; clavus apex acuminate; veins $1 \mathrm{~A}$ and 2A confluent for short distance distally, 2A well developed. Metepimeron concealed by forewing at rest. Legs: prothoracic and mesothoracic tibiae foliaceous (Fig. 14); mesothoracic femur with cucullate setae absent or only distal pair present; tibia with cucullate setal rows absent; metathoracic femur with distal pair of cucullate setae dorsally; tibia (Fig. 15) with cucullate setal rows II and III present, row I development variable. Furcasternum reduced, without lobes. Male. Sternite VI slightly wider than sternites VII and VIII; sternite VII length less than or equal to width; sternite VIII width more than $2 x$ length. Lateral plate of pygofer (Fig. 35) less than half length of subgenital plate; sternite IX anterior margin convex; subgenital plates with apical two-thirds tapering, incompletely fused, uniformly sclerotized, without distinct fenestra. Aedeagus posterior arm weakly curved; shaft broad in lateral view (Figs, 36, 39 ) and strongly compressed in ventral view (Figs 37, 40); gonopore on ventral preapical surface. Style shank straight preapically in lateral view; apex bent and blade-like. Female. Pygofer dorsal posterior margin straight with distinct dorsolateral depressions (Fig. 43). Second valvulae uniformly dentate dorsally (Figs 41, 42, 44).

Revista Brasileira de Zoologia 22 (1): 231-283, março 2005
Distribution. BraziL: Distrito Federal; Espírito Santo; Paraná; Santa Catarina. ColomBia.

Notes. Euwalkeria, previously unplaced to subfamily within Membracidae (Dietrich et al. 2001), is here placed in Nicomiinae based on cladistic analysis (below) of morphological characters. As presently defined, this is the only genus of Membracidae known to include species with and without a posterior pronotal process. Although the new species of Euwalkeria described below differ from the type (E. latipes, known only from the female holotype) in lacking a posterior pronotal process, they are so similar in other features that erecting a separate genus to accommodate them based on this feature alone seems unwarranted, at least until males of $E$. latipes are discovered. The number of cucullate setal rows on the metathoracic tibia is sexually dimorphic in this genus, with rows II and III present in both the male and female and row I weakly developed in the male. The prominent pronotal tubercles are situated posterad of the humeral angles in all species, with $E$. latipes possessing a second, anterior, pair of tubercles.

\section{Key to the Species of Euwalkeria}

1. Pronotum with slender median posterior process extended over scutellum, posterior margin angulate laterally ......... E. latipes (Walker)

1'. Pronotum without median posterior process, posterior margin evenly rounded 2

2. Forewing veins without tubercles; coloration red and yellow E. rubrica Albertson, sp. nov.

2 '. Forewing veins with dark tubercles; coloration various . 3

3. Pronotum with many tubercles (Fig. 32); forewing with large brown macula, veins green . E. perdita Albertson, sp. nov.

3'. Pronotum with one pair of tubercles (Figs 25, 28); forewing without distinct macula, veins variously colored ........... 4

4. Pronotal median carina strongly keeled posterodorsally (Fig. 27); vertex dorsomedial surface flat or only slightly concave E. distincta Albertson, sp. nov.

4'. Pronotal median carina weakly keeled posteriorly (Fig. 25); vertex dorsomedial surface distinctly concave...

$$
\text { E. colorata Albertson, sp. nov. }
$$

\section{Euwalkeria colorata Albertson, sp. nov. Figs 25-26, 35-37, 41}

Type locality. Guaraqueçaba, Paraná, Brazil [UFPC]. Diagnosis. This species differs from other Euwalkeria in having lateral plates with a ventral process and the vertex mottled yellow and orange with black margins and maculae.

Description. Color. Vertex yellow or mottled yellow and orange; dorsal and lateral margins black; black maculae laterad of ocellus and between ocelli; ventral margin pale yellow; frontoclypeus concolorous with vertex dorsally, ventral twothirds black with orange median longitudinal macula; gena black with dorsal one-third and apex yellow, or entirely yel- 


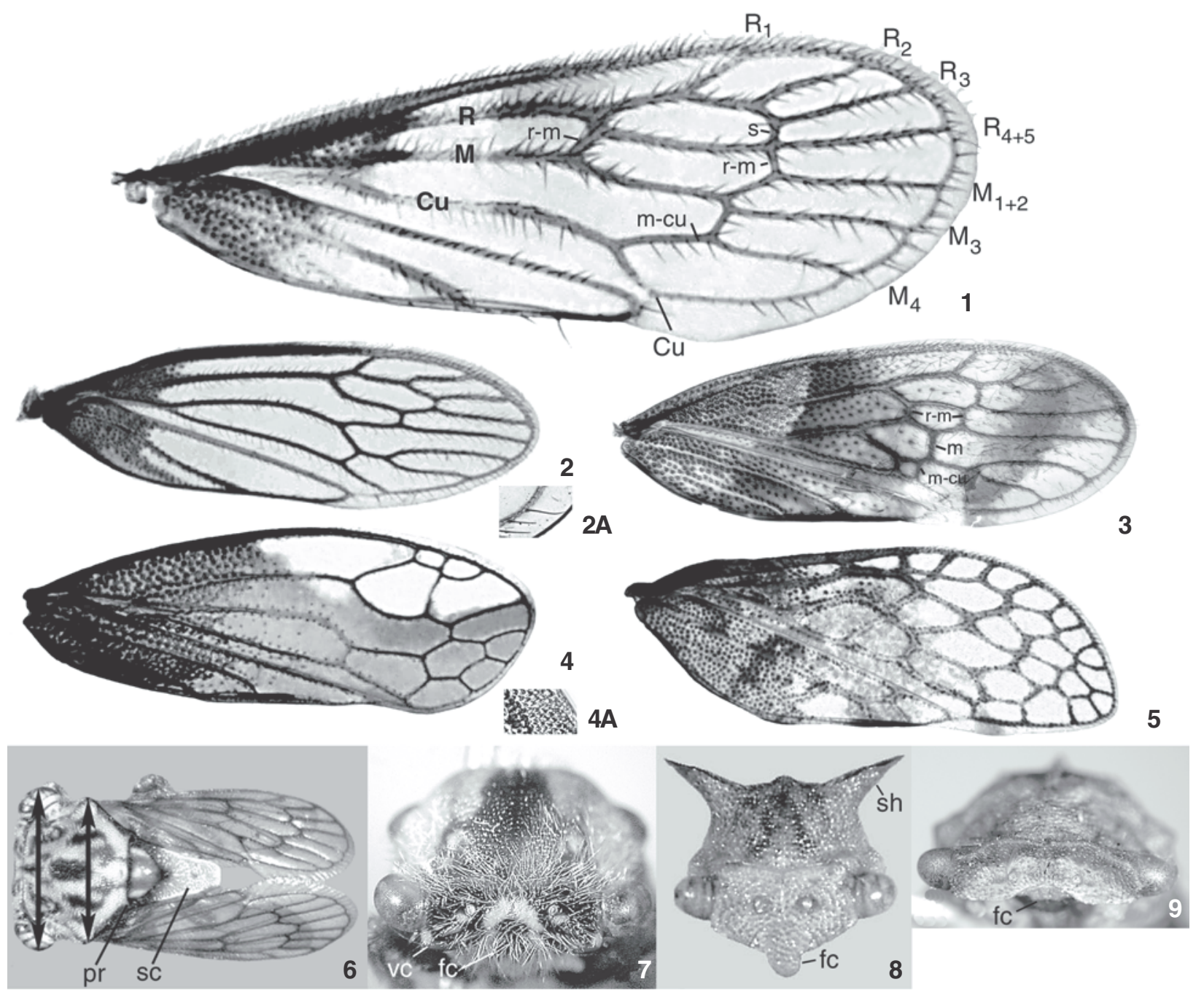

Figures 1-9. (1-5) Wings: (1) Nicomia subfasciata sp. reval., forewing; (2) Tolania sp., forewing; (2A) same, hindwing apex; (3) Stalomia veruta, forewing; (4) Holdgatiella chiloensis, forewing; (4A) same, hindwing apex; (5) Eudonica nanella, forewing; (6) Nicomia inscripta, dorsal view; arrows indicate positions for measuring width of head and width across pronotal humeral angles; (7-9) anterior view: (7) Nicomia subfasciata sp. reval.; (8) Tolania sp.; (9) Euwalkeria rubrica, holotype female. (fc) Frontoclypeus, (pr) posterolateral projection, (sc) scutellum, (sh) suprahumeral horn, (vc) vertex carina.

low. Pronotum mottled yellow and orange or yellow and pale green, punctures concolorous with adjacent areas; metopidium with black maculae; median carina irregularly marked with black; dorsum irregularly marked with black maculae; scutellum yellow; base with orange-brown anterior and posterior margins; thorax black ventrally with yellow near forewing. Forewing basal sclerotization varying from yellow with brown maculae to black basad and yellow distally; membrane hyaline; veins yellow to red. Legs: femora black, yellow, or black and yellow, prothoracic femora with orange spots near ventral apex; tibiae yellow with black base and markings; tarsi yellow with base of tarsomere III black. Head. Vertex with dorsomedial surface distinctly concave. Thorax. Pronotum (Fig. 25) with metopidium sloping, low; ventral postocular carina present, not extended to apex; posterior margin evenly rounded (Fig. 26); posterior process absent. Forewing veins with dark tubercles. Metathoracic tibia with cucullate setal rows II and III present, row I weakly developed in male, absent in female. Male. Lateral plate (Fig. 35) slender and evenly tapered with apex rounded, ventral process present. Aedeagus (Figs 36-37) apex with pair of processes. Female. Second valvulae dorsal margin distinctly angulate (Fig. 41).

Measurements (mm). male/female. Body length 7.9/ 8.3- 

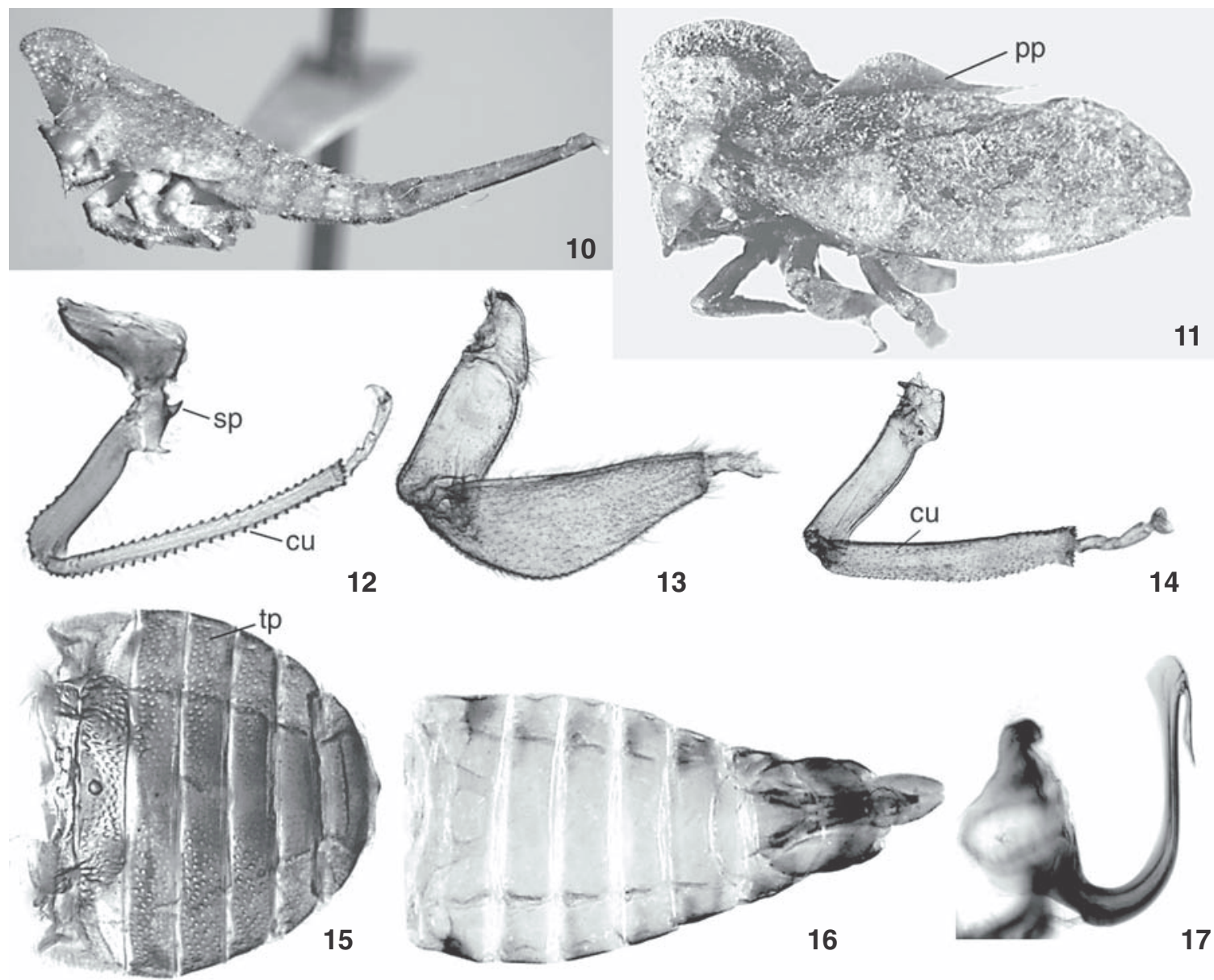

Figures 10-17. (10) Tolania sp., late-instar nymph; (11) Nodonica bispinigera, holotype male, left lateral view. (12) Nicomia sp., metathoracic leg; (13-14) Euwalkeria rubrica: (13) mesothoracic leg; (14) metathoracic leg; (15-16) male abdomen, dorsal view: (15) Nicomia buccina, holotype male, genital capsule removed; (16) Holdgatiella chiloensis, paratype male; (17) Nodonica bispinigera, holotype, aedeagus, lateral view. (cu) Cucullate setal row; (pp) posterior pronotal process, (sp) trochanter spine, (tp) tergal pits.

9.2; head width 3.1/3.1-3.8; pronotal width 3.0/3.0-3.6; forewing length 6.1/6.9-7.9.

Material examined. Holotype male labeled: "GUARAQUEÇABA/ PR - 9-XII-1970/ V.O. Becker LEG./ a luz; Albertson Research/ EUW-0840 ơ; Holotype/ Euwalkeria/ colorata/ Albertson" [UFPC]. Paratypes: 1 male, same data (Albertson Research EUW-0795) [UFPC]; 1 female, BraziL, Paraná: "Foz do Iguaçu", 7 December 1966, mercury vapor lamp, (Albertson Research EUW-0756 female) [UFPC]; 1 female, Santa Catarina: Corupa (= Hansa Humbolt), January 1946, A. Maller, CHD Research \#98-0005 (Albertson Research EUW-0357 female) [USNM]; 1 female, Santa Catarina: Seara, Nova Teutônia, 26 November 1943, Remett, Plaumann, Pflanze No. 219 (Albertson Research EUW-0354 female) [UFPC], 1 female, same data, Dietrich Research 15-91-40f female (Albertson Research EUW0358 female) [UFPC]; 1 female, BraziL, Distrito Federal: nr. Pla- naltina \& EMBRAPA-CPAC 19 March 1999, M.J. \& C.A. Tauber (Albertson Research EUW-1000 female) [UCB].

Distribution. BraziL: Distrito Federal; Paraná; Santa Catarina. Collection dates: January, March, and November to December.

Notes. The name 'colorata' is Latin for "colored" and refers to the mottled appearance of the adults. The pronotum median keel is more pronounced in the female than in the male.

\section{Euwalkeria distincta Albertson, sp. nov. Figs $27-28,42$}

Type locality. Linhares, Espírito Santo, Brazil [UFPC].

Diagnosis. This species differs from other Euwalkeria in having a high, nearly vertical metopidium and the median carina strongly keeled posteriorly. 


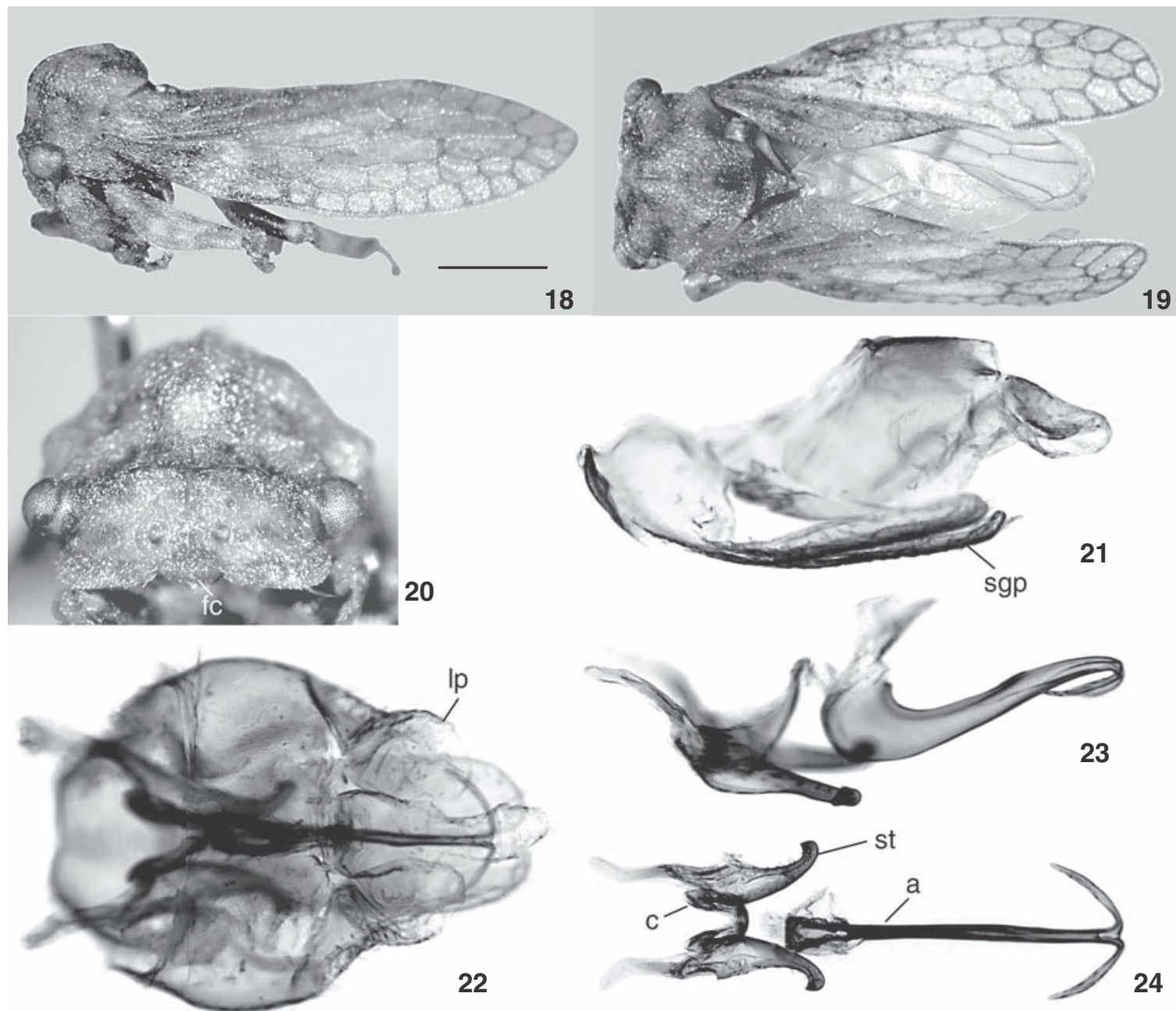

Figures 18-24. Eudonica nanella, holotype male: (18) left lateral view; (19) dorsal view; (20) anterior view; (21) pygofer, lateral view; (22) pygofer, dorsal view; (23) genitalia, lateral view; (24) genitalia, dorsal view. (a) Aedeagus, (c) connective, (fc) frontoclypeus, (lp) lateral plate, (sgp) subgenital plate, (st) style.

Description. Female. Color. Vertex yellow; thin red transverse line dorsally; black maculae mesad of ocellus and ventrolaterad of ocellus; frontoclypeus and gena yellow dorsally, ventral two-thirds black. Pronotum yellow and brown, punctures concolorous with adjacent areas; irregularly marked with black maculae; arcuate black macula posteriorly; scutellum yellow; ventral thorax black with yellow near forewing. Forewing basal sclerotization orange with yellow apical macula; membrane hyaline; veins yellow; clavus commisural margin with black macula preapically. Legs: pro- and mesothoracic femora yellow with black anterior macula, metathoracic femora yellow; tibiae yellow with red maculae; tarsi yellow with brown to black ventrally. Head. Vertex dorsomedial surface flat. Thorax. Pronotum (Fig. 27) with metopidium high, nearly vertical; median carina strongly keeled posteriorly; ventral postocu- lar keel carina not extended to apex; with numerous tubercles; posterior margin evenly rounded (Fig. 28); posterior process absent. Forewing veins with dark tubercles. Metathoracic tibia with cucullate setal rows II and III present. Abdomen. Second valvulae dorsal margin distinctly angulate (Fig. 42).

Male. Unknown.

Measurements (mm). Female. Body length 7.4; head width 3.1; pronotal width 3.0; forewing length 6.3 .

Material examined. Holotype female: "LINHARES - ES/ Brasil - IX/ 1972/ M. Alvarenga; Albertson Research/ EUW-0757 female; Holotype/ Euwalkeria/ distincta/ Albertson" [UFPC].

Distribution. Brazil: Espírito Santo. Collection date: November.

Notes. The name 'distincta' is Latin for "distinct" and refers to the distinctly keeled pronotum.

Revista Brasileira de Zoologia 22 (1): 231-283, março 2005 

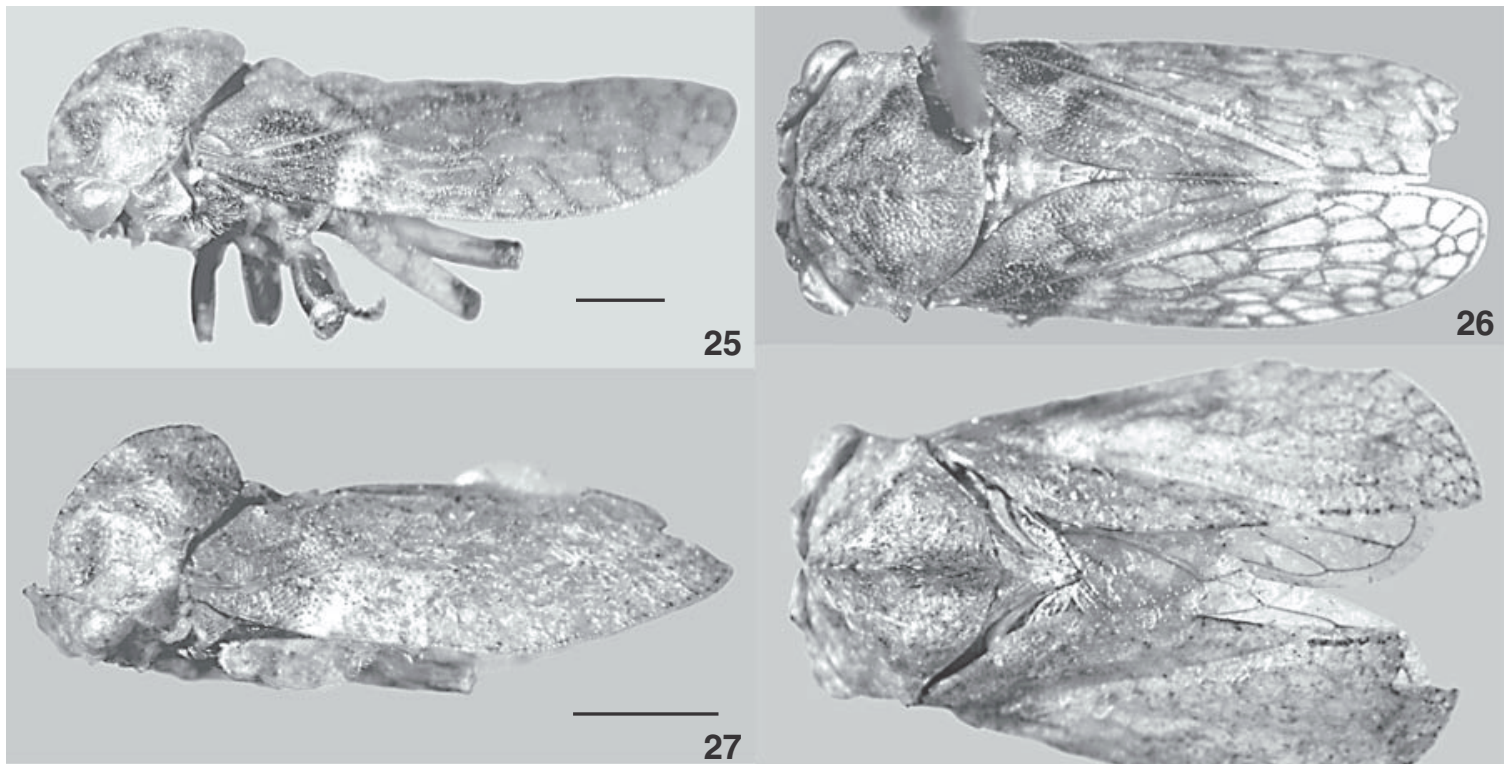

27
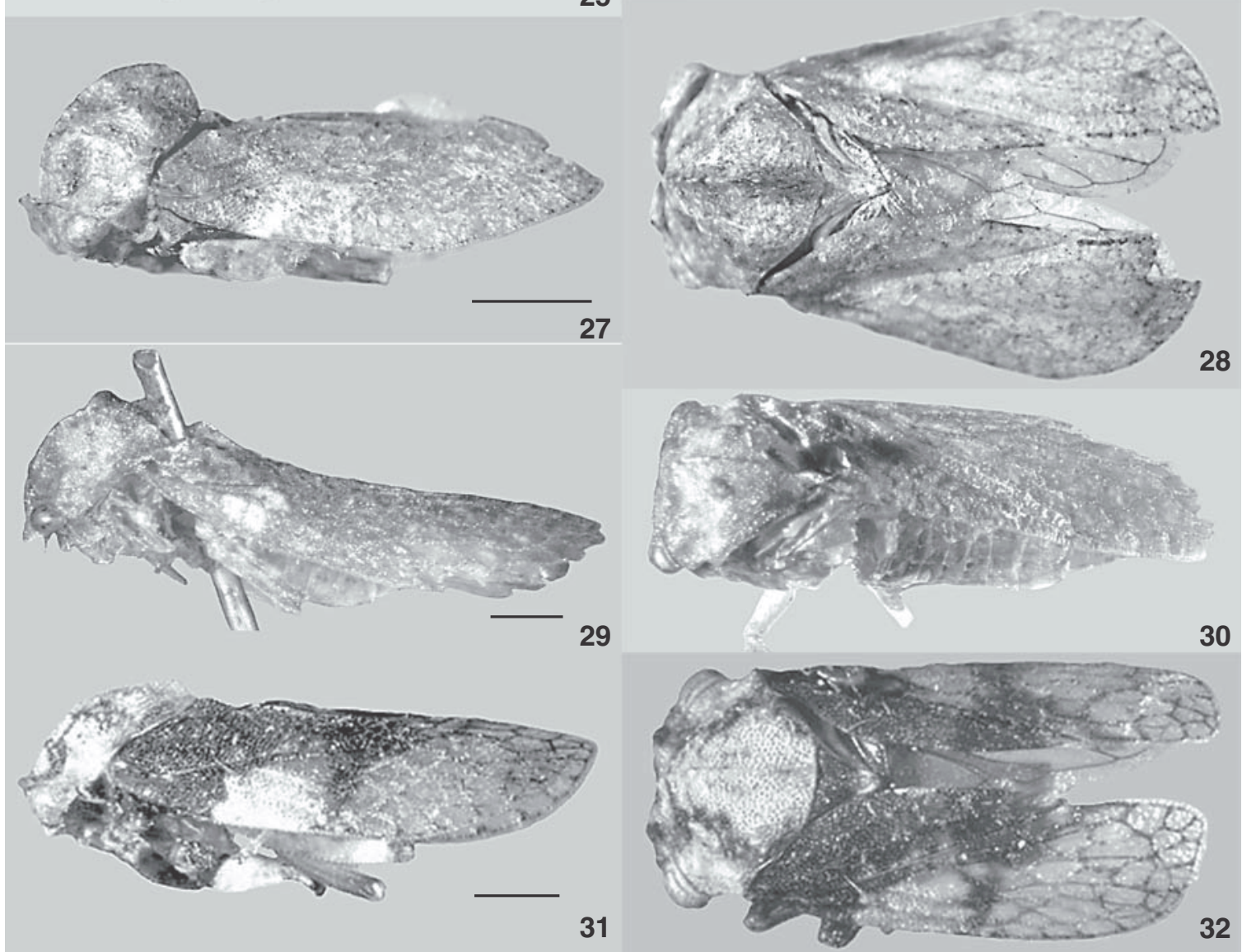

Figures 25-32. Euwalkeria, adult lateral and dorsal habitus. (25-26) E. colorata holotype male; (27-28) E. distincta holotype female; (2930) E. latipes (Walker), holotype female; (31-32) E. perdita, holotype male.

\section{Euwalkeria latipes (Walker, 1851) \\ Figs 29-30}

Aethalion [sic] latipes Walker, 1851: 649.

Euwalkeria latipes; Goding, 1926a: 104.

Type locality. Colombia.

Diagnosis. This species differs from other Euwalkeria in having a posterior pronotal process partially concealing the scutellum dorsally.

Description. Female. Color. Vertex yellow with red-brown maculae on dorsal and lateral margins; frontoclypeus and gena yellow. Pronotum yellow dorsally, red-brown posterad of suprahumeral tubercles, punctures concolorous with adjacent areas or red; red-brown macula forming arc across metopidium; scutellum red-brown; ventral thorax yellow. Forewing basal sclerotization mottled red and yellow, 2 pale irregular maculae at base of corium; membrane hyaline; veins reddish yellow. Legs: mesothoracic femur yellow with apical red macula dorsally; metathoracic femur yellow; tibiae yellow with red transverse maculae. Head. Vertex with dorsomedial surface distinctly concave; concave laterad of ocellus. Thorax. Pronotum with metopidium sloping, low (Fig. 29); ventral postocular carina

Revista Brasileira de Zoologia 22 (1): 231-283, março 2005 
well developed, posteroventral margin acute; with suprahumeral and posterior tubercles; posterior margin angulate; posterior process present and partially concealing scutellum dorsally. Forewing veins without dark tubercles. Metathoracic tibia with only cucullate setal rows II and III present. Abdomen. Second valvulae abruptly broadened near midlength.

Male. Unknown.

Measurements (mm). Female. Body length 10.6; head width 3.7; pronotal width 3.7; forewing length 8.6.

Material examined. Holotype female: "Type; 43/ 64; Deitz Research/ 73-972 i; 8. Aethalion [sic] latipes.; Albertson Research/ EUW-1026 \%" [BMNH].

Distribution. Colombia.

Notes. The name 'latipes' translates from Latin as "broad foot", presumably referring to the foliaceous tibiae.

\section{Euwalkeria perdita Albertson, sp. nov.} Figs $31-32,38-40$ [UFPC].

Type locality. Conceição da Barra, Espírito Santo, Brazil

Diagnosis. This species differs from other Euwalkeria in having a pronotum with many tubercles, forewing with transverse fuscous macula, and green color on the pronotum.

Description. Male. Color. Vertex yellow with brown maculae along dorsal and lateral margins; brown M-shaped macula mesad of ocellus; frontoclypeus yellow dorsally, ventral twothirds black. Pronotum yellow, pale green posteriorly, punctures concolorous with adjacent areas; brown macula extending from anterior margin to posterolateral margin; lateral margin from humeral angle posterad brown; scutellum base dark brown with pale median longitudinal macula, apex yellow-orange; ventral thorax yellow. Forewing basal sclerotization of corium brown on basal one-third, distal two-thirds yellow, clavus brown with yellow maculae; membrane hyaline with transverse fuscous macula near midlength; veins pale green. Legs: pro- and mesothoracic femora brown with yellow base and venter, metathoracic femur yellow with brown apex; tibiae yellow with brown maculae, meso- and metathoracic tibiae brown basally; tarsi entirely green or green with brown venter, tarsomere III with transverse brown stripe distally. Head. Vertex dorsomedial surface flat. Thorax. Pronotum with metopidium sloping, low (Fig. 31 ; ventral postocular carina not extended to apex; with numerous tubercles; posterior margin evenly rounded; posterior process absent. Forewing veins with dark tubercles. Metathoracic tibia with cucullate setal rows II and III present, row I weakly developed. Abdomen. Lateral plate robust (Fig. 38). Aedeagus apex with pair of processes (Fig. 40).

Female. Unknown.

Measurements (mm). Male. Body length 6.5; head width

3.1; pronotal width 3.0; forewing length 5.1.

Material examined. Holotype male: "PEDRO CANARIO

- ES/ Conceição da Barra/ Brasil - X/1972/ M. Alvarenga leg; Deitz Research/ 9-1-130g ơ; Albertson Research/ EUW-0841 ơ;
Holotype/ Euwalkeria/ perdita/ Albertson" [UFPC].

Distribution. Brazil: Espírito Santo. Collection date: October.

Notes. The name 'perdita' translates from Latin as "the lost one" and is the name of a character in Shakespeare's The Winter's Tale.

\section{Euwalkeria rubrica Albertson, sp. nov. Figs 9, 13-14, 33-34, 43-44}

Type locality. Brazil [MNHN].

Diagnosis. This species differs from other Euwalkeria in lacking dark tubercles on the forewing veins and in the red and yellow coloration.

Description. Female. Color. Vertex yellow with red maculae on dorsal and lateral margins; frontoclypeus red, dorsal third yellow; gena yellow. Pronotum mottled red and yellow, punctures concolorous with adjacent areas; metopidium with pair of black semicircular maculae; scutellum base mottled red and yellow; apex yellow; ventral thorax yellow. Forewing basal sclerotization red with yellow maculae; membrane hyaline to yellowish; veins red; clavus commisural margin with black apex. Legs: femora yellow with faint red maculae; tibiae red with faint yellow transverse maculae; tarsi dark yellow. Head. Vertex dorsomedial surface flat. Thorax. Pronotum with metopidium sloping, low (Fig. 33); ventral postocular keel carina well developed, posteroventral margin acute; posterior margin evenly rounded; pronotum posterior process absent. Forewing veins without dark tubercles. Metathoracic tibia with only cucullate setal rows II and III present. Abdomen. Second valvulae width more or less uniform throughout (Fig. 44).

Male. Unknown.

Measurements (mm). Female. Body length 6.1; head width 2.7; pronotal width 2.6; forewing length 5.3.

Material examined. Holotype female: "Bresil [sic]; 7R; Nicomia/ sp.; Albertson Research/ EUW-0946 ; Holotype/ Euwalkeria/ rubrica/ Albertson" [MNHN].

Distribution. BrazIL. Collection date: unknown.

Notes. The name 'rubrica' is Latin for "red earth" and refers to the coloration of the adult.

\section{Holdgatiella Evans, 1962}

Holdgatiella Evans, 1962: 515.

Type species: Holdgatiella chepuensis Evans, 1962, by original designation.

Diagnosis. Holdgatiella differs from other Nicomiinae in having the following combination of features: frontoclypeus convex but not produced ventrally; posterior pronotal process absent; forewing vein $\mathrm{R}$ with 3 or more branches and 2 or more $\mathrm{m}$-cu crossveins; hindwing apex with arcuate chaetoids.

Description. Head. Vertex width between eyes more than $2 \mathrm{x}$ height (Fig. 47); dorsal processes closer to midline than to eyes, conical; ventrolateral margins carinate; ocelli not elevated. Frontoclypeus convex but not produced ventrally. Thorax. Dis-

Revista Brasileira de Zoologia 22 (1): 231-283, março 2005 

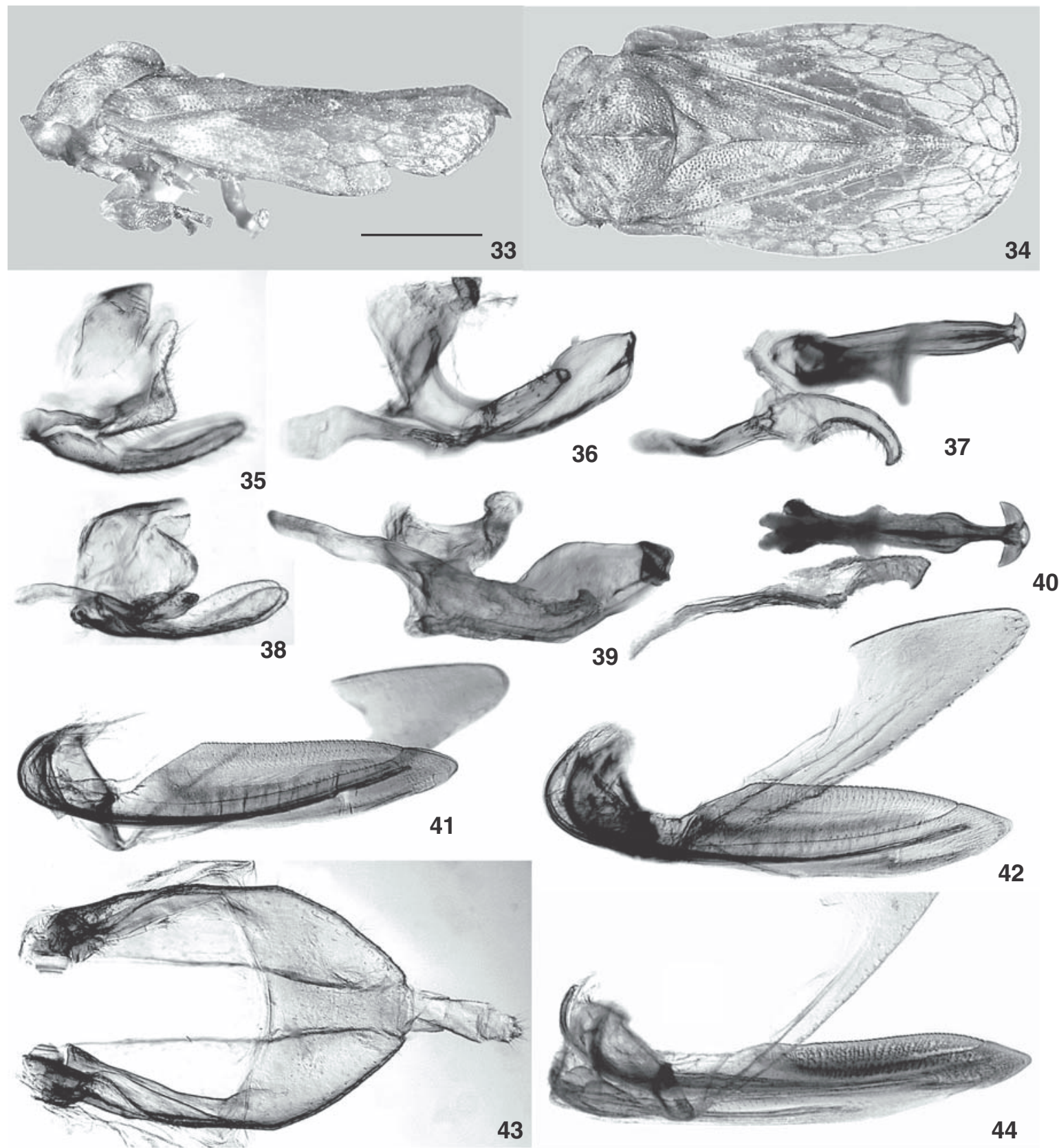

Figures 33-44. Euwalkeria. (33-34) E. rubrica holotype female: (33) left lateral view; (34) dorsal view; (35-40) males: (35-37) E. colorata holotype: (35) genital capsule, lateral view; (36) genitalia, lateral view; (37) same, dorsal view; (38-40) E. perdita holotype: (38) genital capsule, lateral view; (39) genitalia, lateral view; (40) same, dorsal view; (41) E. colorata paratype female, second and third valvulae; (42) E. distincta holotype female, second and third valvulae; (43-44) E. rubrica holotype: (43) pygofer, dorsal view; (44) second and third valvulae.

tance from eye to wing base less than half eye width. Pronotum with metopidium sloping, low (Fig. 45); punctation dense; dorsal pubescence short; median carina visible but only slightly elevated; suprahumeral horns and tubercles absent; posterior pro- cess absent; posterior margin straight, without angles, posterolateral projections absent. Scutellum base slightly inflated; apex narrow, acuminate (Fig. 46); posterior medial groove indistinct. Forewing (Fig. 4) vein R with 3 or more branches; $1 \mathrm{~s}$ crossvein,

Revista Brasileira de Zoologia 22 (1): 231-283, março 2005 
basad of r-m crossvein; 1 r-m crossvein; 2-3 m-cu crossveins, distal $\mathrm{m}$-cu crossvein connected between first and second $\mathrm{M}$ fork. Clavus apex acuminate; veins $1 \mathrm{~A}$ and 2A free, 2A well developed. Hindwing apical membrane with arcuate chaetoids (Fig. 4A); crossvein $\mathrm{m}$-cu subparallel to $\mathrm{M}_{3+4}$ before angle and apex of cell acute. Metepimeron concealed by forewing at rest. Legs: pro- and meso- thoracic tibiae slender; metathoracic femur ventral longitudinal cucullate setal row present; tibia, cucullate setal rows I, II, and III present. Furcasternum reduced, without lobes. Tymbals absent or indistinct. Male. Aedeagus posterior arm straight; shaft tubular (Figs 50-51); apex only slightly enlarged compared to shaft. Style shank strongly curved dorsally near connective and gradually descending toward apex; apex compressed and acutely produced dorsally (Fig. 50). Female. Pygofer dorsal posterior margin straight, dorsolateral depressions indistinct (Fig. 52).

Distribution. CHILE: Los Lagos.

Notes. Holdgatiella was previously unplaced to subfamily within Membracidae (Dietrich et al. 2001) and is here included in Nicomiinae based on cladistic analysis (see below). This is the only nicomiine genus with arcuate chaetoids on the hindwing apical membrane; a feature also present in Stegaspidinae. However, Holdgatiella is more appropriately placed in the Nicomiinae based on the forewing venation and the presence of aedeagal processes. The number of vein $\mathrm{R}$ branches varies within the genus, ranging from three in $H$. chepuensis to four in H. chiloensis.

\section{Key to the Species of Holdgatiella}

1. Aedeagus with 5 pairs of apical processes; female second valvulae abruptly broadened distally...H. chepuensis Evans

1'. Aedeagus with 4 pairs of apical processes (Fig. 51); female second valvulae width more or less uniform throughout H. chiloensis Albertson, sp. nov.

\section{Holdgatiella chepuensis Evans, 1962}

Holdgatiella chepuensis Evans, 1962: 516.

Type locality. Chepu, Los Lagos, Chile.

Diagnosis. This species differs from other Holdgatiella in having an aedeagus with five pairs of apical processes.

Distribution. CHILE: Los Lagos.

Notes. A description and illustrations of this species were provided by Cryan \& Deitz (2002) and Linnavouri \& DeLong (1978). The name 'chepuensis' refers to the location where the type specimen was collected.

\section{Holdgatiella chiloensis Albertson, sp. nov. Figs 4, 4A, 16, 45-53}

Type locality. 6km N Quellon, Los Lagos, Chile [USNM]. Diagnosis. This species differs from other Holdgatiella in having an aedeagus with four pairs of apical processes.

Description. Color. Vertex black; dorsal margin, medial line, and ventral margin yellow to orange; frontoclypeus black with yellow dorsal and lateral margins. Pronotum yellow, punc- tures brown to black; metopidium and dorsum with black maculae; scutellum yellow to orange; ventral thorax black with yellow maculae or yellow. Forewing basal sclerotization brown; membrane fuscous, hyaline anterad of vein R; veins yellow to brown. Legs yellow or yellow with brown dorsally. Head. Vertex with setae short, pale, dense; dorsomedial surface distinctly concave. Frontoclypeus with median longitudinal carina. Thorax. Pronotum (Figs 45-46) with setae short, pale, sparse; dorsal postocular keel well developed; ventral postocular keel absent. Scutellum (Fig. 46) without punctures; setae short, pale, sparse. Forewing (Fig. 4) with $2 \mathrm{~m}$-cu crossveins; $1 \mathrm{~m}$ crossvein. Mesothoracic femur with distal pair of cucullate setae; tibia without cucullate setal rows. Metathoracic femur with irregular longitudinal cucullate setal row dorsally, anterolateral cucullate setae present, concentrated on apical one-third. Male. Lateral plate (Fig. 48) less than half as long as subgenital plate, robust; subgenital plates incompletely fused, with sub-basal constriction and apical two-thirds tapering, uniformly sclerotized without distinct fenestra. Aedeagus apex with 4 pairs of processes (Fig. 51); gonopore on ventral preapical surface. Female. Second valvulae width more or less uniform throughout; uniformly dentate dorsally (Fig. 53).

Measurements (mm). Body length male 5.9, female 6.5; head width male 2.4 , female 2.7 ; pronotal width male 2.1 , female 2.4; forewing length male 5.2, female 5.7.

Material examined. Holotype male: "Chile: $6 \mathrm{~km} . / \mathrm{N}$. Quellon/ Chiloe Is/ II-6-1968; Collectors: L \&/ C.W. O’Brien; Albertson Research/ HOL-0128 ơ; Holotype/ Holdgatiella/ chiloensis/ Albertson" [USNM]. Paratypes: 1 male, CHILE: Los Muermos forest, 2 January 1951, Ross \& Michelbacher (Albertson Research HOL-0144 male)"; 1 female, same data (Albertson Research HOL-0355) [CAS]; 1 [sex unknown], 30 km. E. Payehue, Osorno, 25 January 1951; Ross \&/ Michelbacher (Albertson Research HOL-0362) [CAS].

Distribution. ChILE: Los Lagos. Collection dates: January to February.

Notes. The name 'chiloensis' refers to Chiloe Island on which the species occurs.

\section{Nicomia Stål, 1858}

Nicomia Stål, 1858: 249.

Type species: Nicomia lemniscata Stål, 1858, by subsequent designation of Funkhouser, 1927.

Diagnosis. Nicomia differs from other Nicomiinae in having the following combination of features: frontoclypeus flattened ventrally; forewing with two r-m crossveins; mesothoracic tibiae cucullate setal rows absent; metathoracic trochanter spinose, tibia with cucullate setal rows II and III; abdomen ovoid with male genital capsule retracted.

Description. Head. Vertex width between eyes more than twice height; dorsal processes indistinct (except $N$. interrupta with distinct processes); carina extending from ocelli ventrolaterally, distinct or indistinct; ventrolateral margins carinate. 


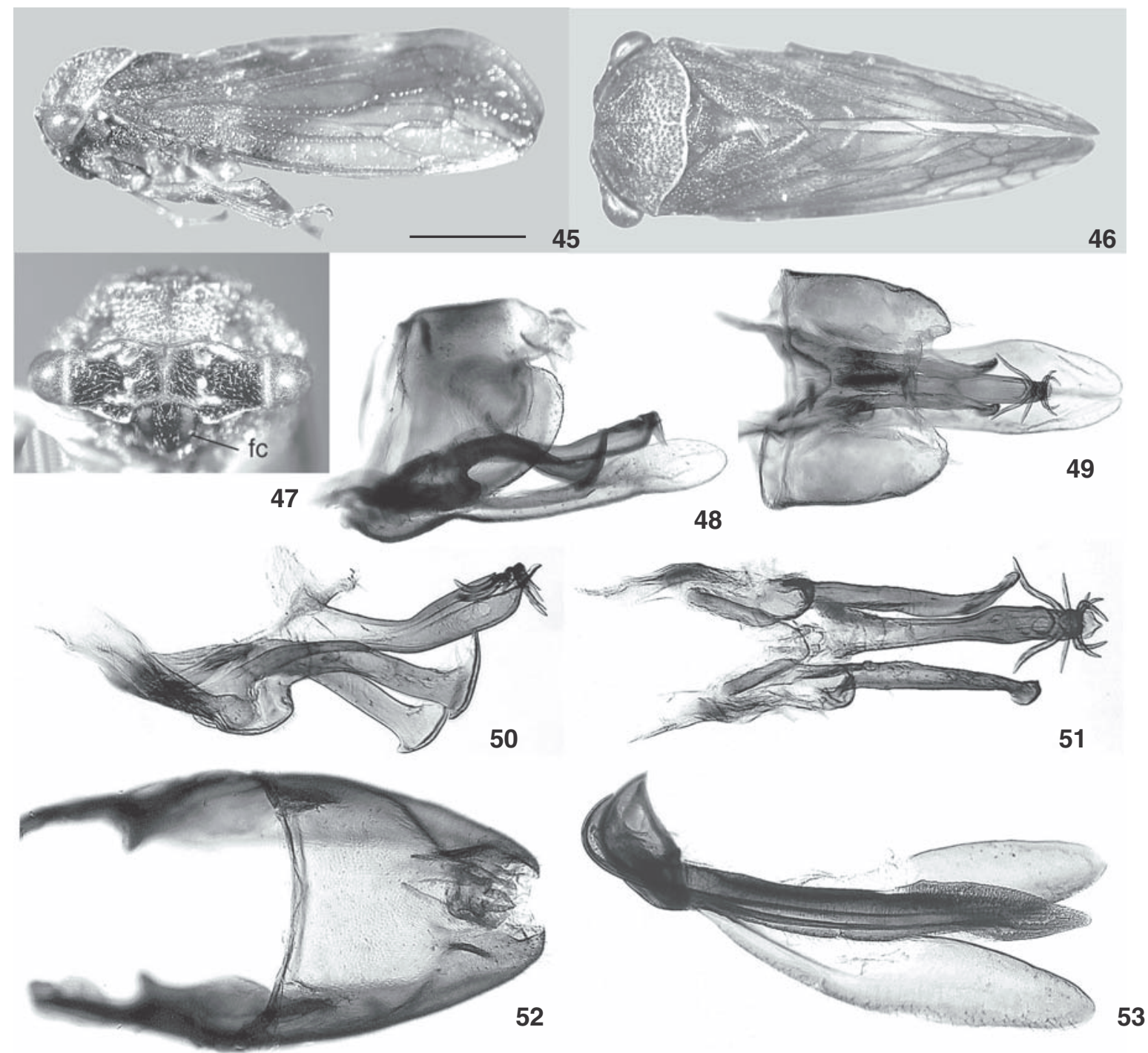

Figures 45-53. Holdgatiella chiloensis. (45-47) Paratype female: (45) left lateral view; (46) dorsal view; (47) anterior view; (48-51) male: (48) genital capsule, lateral view; (49) same, dorsal view; (50) genitalia, lateral view; (51) same, dorsal view; (52-53) female: (52) pygofer, dorsal view; (53) second and third valvulae. (fc) Frontoclypeus.

Ocelli with medial margins slightly elevated. Frontoclypeus flattened; transverse dorsal depression present; transverse carina or fold absent; setae long and dense. Thorax. Distance from eye to wing base less than half eye width. Pronotum (Figs 54-77) with metopidium sloping, low; punctation dense; dorsal pubescence short; median carina visible but only slightly elevated; dorsal postocular keel absent; suprahumeral horns and tubercles absent; posterior margin straight, angulate laterally, with posterolateral projections well developed. Scutellum apex broad, truncate; coarsely punctuate (Figs 54-77). Forewing (Fig. 1) with $1 \mathrm{~s}$ crossvein; $2 \mathrm{r}-\mathrm{m}$ crossveins, r-m 1 basad of $\mathrm{R}_{1}$ and perpendicular to veins $\mathrm{R}$ and $\mathrm{M} ; 1 \mathrm{~m}$-cu crossvein, con- nected distad of second $\mathrm{M}$ fork; crossvein $\mathrm{m}$ absent; clavus apex oblique, truncate; veins $1 \mathrm{~A}$ and $2 \mathrm{~A}$ free, $2 \mathrm{~A}$ weak. Metepimeron exposed by forewing at rest. Legs: pro- and mesothoracic tibiae slender with long white setae; mesothoracic femur with distal pair of cucullate setae dorsally; tibia cucullate setal rows absent; metathoracic trochanter spines present; femur with preapical cucullate setae; tibia with cucullate setal rows II and III. Furcasternum lobed (Fig. 78). Tymbals large and conspicuous, extending past posterior margin of metathorax. Abdomen. Abdominal segments III-VIII ovoid (Fig. 15); terga and pygofer dorsum with conspicuous pits present or absent; apodemes in segments IV, V, and VI absent. Male. Sternite VI slightly wider

Revista Brasileira de Zoologia 22 (1): 231-283, março 2005 
than sternites VII and VIII; sternite VII length less than width; sternite VIII width more than $2 x$ length. Male genital capsule retracted into pregenital segment; lateral plate apparently small and situated more dorsally than in other genera (Fig. 81), less than half length of subgenital plate (except $N$. notidana), apex strongly curved medially. Female. Pygofer with dorsal posterior margin emarginate adjacent to anal tube; with dorsolateral depressions distinct (Fig. 111).

Distribution. BraziL: Amazonas; Espírito Santo; Rio de Janeiro; Santa Catarina. Ecuador: Napo. French Guiana: SaintLaurent du Maroni. Guyana: Cuyuni-Mazaruni. Panama: Panama; San Blas. Peru: Madre de Dios. Venezuela: Amazonas.

Notes. This genus closely resembles Stalomia but is easily distinguished by features of the metathoracic trochanter (armed with spines), two rows of cucullate setae on the metathoracic tibia, and the male abdomen ovoid in dorsal view with the genital capsule retracted into the abdomen.

Key to the species of Nicomia, males (excluding N. harenosa sp. nov., and lemniscata Stål, known only from females)

1. Abdominal terga without conspicuous pits; furcasternum with anterior lobes only. 2

1'. Abdominal terga with conspicuous pits (Fig. 15); furcasternum with anterior lobes or anterior and posterior lobes (Fig. 78)

2. Scutellar keel present (Fig. 66); vertex ventrolateral carina indistinct; metopidium and pronotal dorsum yellow with numerous small black maculae; forewing basal sclerotization black ......................... . monticola Albertson, sp. nov.

2 '. Scutellar keel absent; vertex ventrolateral carina distinct (Fig. 7); with large black macula on metopidium extending on to dorsum of pronotum; forewing basal sclerotization yellow-orange ...................... N. subfasciata Stål, sp. reval.

3. Pygofer without conspicuous pits dorsally, anterior carina absent (Fig. 80)

3 '. Pygofer with conspicuous pits dorsally (Figs 79, 80), anterior carina absent or present (Fig. 79)

4. Vertex dorsomedial surface distinctly concave; pronotum color variable but without distinct stripes; forewing membrane with transverse fuscous macula; aedeagus shaft tubular, with large, style-like processes arising from base (Figs 85, 86) N. interrupta Stål

4 '. Vertex dorsomedial surface flat; pronotum yellow with redbrown longitudinal stripes; forewing membrane without maculae; aedeagus shaft tubular or strongly compressed in ventral view, without style-like processes

5. Aedeagus shaft compressed, broad in lateral view (Figs 91, 92), processes absent ............ jucunda Albertson, sp. nov.

5 '. Aedeagus shaft tubular, with dorsal preapical process (Fig. 100) N. notidana Albertson, sp. nov.

6. Vertex carina distinct (Fig. 7); pronotum yellow anteriorly, pale green posteriorly with dorsal black macula; aedeagus with pair of dorsal, serrate flanges (Fig. 106) N. serrata Albertson, sp. nov.

6 '. Vertex carina indistinct or absent; aedeagus without dorsal flanges

7

7. Forewing s crossvein distad of distal $r-m$ crossvein; furcasternum with anterior lobes only; aedeagus with serrate flange surrounding apex and extending partially along shaft ventrally (Fig. 97) ........ N. nigrifasciata Albertson, sp. nov.

7 '. Forewing s crossvein basad of distal r-m crossvein; furcasternum with anterior and posterior lobes (Fig. 78); aedeagus without flange 8

8. Scutellum base produced dorsally; aedeagus shaft sparsely clothed with setae (Figs 103, 104), apical processes absent N. pulchella Albertson, sp. nov.

8'. Scutellum base flat or slightly inflated; aedeagus glabrous, apical processes present

9

9. Aedeagus shaft broad in lateral view and strongly compressed in ventral view (Figs 88, 89); pygofer without dorsal carina; metathoracic trochanter with 3 spines; gena black; forewing basal sclerotization black...N. inscripta Albertson, sp. nov.

9'. Aedeagus shaft tubular (Figs 82, 83); pygofer with anterodorsal carina (Fig. 79); metathoracic trochanter with 2 spines; gena yellow; forewing basal sclerotization yellow to yellow-orange ................. N. buccina Albertson, sp. nov.

Key to the species of Nicomia, females (excluding N. buccina sp. nov., N. monticola sp. nov., $N$. nigrifasciata sp. nov, and $N$. notidana sp. nov., known only from males)

1. Abdominal terga without conspicuous pits N. subfasciata Stål, sp. reval.

$1^{\prime}$. Abdominal terga with conspicuous pits (Fig. 15) ............ 2

2. Furcasternum with anterior lobes only; metathoracic trochanter with 2 to 4 spines ........................................ 3

2'. Furcasternum with anterior and posterior lobes (Fig. 78); metathoracic trochanter with 3 spines ............................ 5

3. Metathoracic trochanter with 3 or 4 spines; vertex carina distinct (Fig. 7); second valvulae uniformly dentate (Figs $118,124)$; pronotum yellow and usually marked with black maculae 4

3 '. Metathoracic trochanter with 2 spines; vertex carina absent; second valvulae irregularly dentate (Fig. 112); pronotum mottled yellow and orange-brown .....

... N. harenosa Albertson, sp. nov.

4. Metathoracic trochanter with 4 spines; forewing basal sclerotization black ............. N. jucunda Albertson, sp. nov.

4'. Metathoracic trochanter with 3 spines; forewing basal sclerotization yellow ........... N. serrata Albertson, sp. nov.

5. Scutellum base produced dorsally ................................... 6

5'. Scutellum base only slightly inflated ............................... 7

6. Pronotum with various maculae; scutellum base yellow with black stripes; vertex carina distinct (Fig. 7); second valvulae

Revista Brasileira de Zoologia 22 (1): 231-283, março 2005 
with dorsal margin more or less evenly arcuate throughout (Fig. 122) ......................... N. pulchella Albertson, sp. nov.

6'. Pronotum with four black longitudinal maculae extending from dorsal pronotum to posterior margin (Fig. 65); scutellum base red; vertex carina indistinct; second valvulae with dorsal margin distinctly angulate (Fig. 120)

N. lemniscata Stål

7. Vertex dorsomedial surface distinctly concave; vertex carina distinct (Fig. 7); forewing membrane with transverse fuscous macula; pygofer without conspicuous pits dorsally .........

.. N. interrupta Stål

7'. Vertex dorsomedial surface flat; vertex carina indistinct; forewing maculae absent; pygofer with conspicuous pits dorsally ................................. inscripta Albertson, sp. nov.

\section{Nicomia buccina Albertson, sp. nov.}

\section{Figs $15,54-55,81-83$}

Type locality. Alajuela, Panama, Panama [USNM].

Diagnosis. This species differs from other Nicomia in having abdominal terga with conspicuous pits, the male pygofer with a dorsal anterior carina, and the aedeagus with the apex slightly wider than the shaft and the gonopore large and apical.

Description. Male. Color. Vertex dark yellow; black maculae on dorsolateral margin, surrounding ocellus, ventrolaterad of ocellus, and on ventrolateral margin; frontoclypeus with dorsal black arcuate macula and red sutures; gena yellow. Pronotum mottled yellow and orange, punctures orange; metopidium with black supraocular callosity and lateral black macula extending posteriorly and meeting median carina dorsally; median carina with black maculae anteriorly; lateral margins posterior to humeral angles dark brown; scutellum base dark yellow with faint orange maculae and red-orange apically; apex pale yellow. Forewing basal sclerotization dark yellow to orange with dark brown veins; membrane hyaline; veins brown with pale area basad of first $\mathrm{R}$ fork. Legs: femora orange-brown with yellow ventral macula; tibiae yellow with faint transverse orange maculae, apex brown; tarsi brown with yellow macula at base of third tarsomere. Head. Vertex covered with long setae, setae dorsad of imaginary line across vertex through ocelli white, dark ventrally; dorsomedial surface flat; ventrolateral carina indistinct; frontoclypeus with long white setae. Thorax. Pronotum covered with white and dark setae; ventral postocular keel absent. Scutellum (Figs 54-55) base slightly inflated, with long dark setae dorsally, long white setae laterally; posterior lobe punctate, midline medial groove indistinct. Forewing veins with dark setae; s crossvein basad of distal r-m crossvein. Legs: metathoracic trochanter with 2 spines, spine I large, spine II weakly developed. Furcasternum with elongate, curved anterior lobe and short, elongate posterior lobes. Abdomen. Terga with conspicuous pits; sternite III with weak medial keel; pygofer with conspicuous pits dorsally.
Sternite VIII with anterior carina; posterior margin with weak keeled projection. Pygofer with anterior carina dorsally and extending for a short distance laterally; lateral plate digitiform (Fig. 81); sternite IX anterior margin straight; subgenital plates completely fused, with apical two-thirds tapering, with densely sclerotized lateral ridge (with setae) and median basal fenestra (glabrous). Aedeagus (Figs 82-83) posterior arm straight; shaft tubular; apex slightly broader than shaft, with one pair of short arcuate processes; gonopore apical. Connective anterior margin convex; posterior apex produced into short arm. Style apodeme strongly curved laterally (Fig. 83); shank short with abrupt lateral bend medially; apex bent and blade-like.

Female. Unknown.

Measurements (mm). Male. Body length 6.3; head width 3.0; pronotal width 2.9; forewing length 5.2.

Material examined. Holotype male: "Alhajuelo [sic]/ Pan[ama] Apr 15.11/ August Busck; Nicomia/ cicadoides/ Walk. [misidentification]/ (F.W.; Membracoidea/ Phylogeny, NCARS/ Proj. \#NC 03979; Albertson Research/ NIC-0126 ơ; Holotype/ Nicomia/ buccina/ Albertson" [USNM].

Distribution. Panama: Panama. Collection date: April.

Notes. The name 'buccina' is Latin for "trumpet" and refers to the shape of the aedeagus.

\section{Nicomia harenosa Albertson, sp. nov.} Figs $57-57,111-112$

Type locality. $1 \mathrm{~km} \mathrm{~S}$ Onkonegare, Napo, Ecuador [USNM].

Diagnosis. This species differs from other Nicomia in having abdominal terga with conspicuous pits and a densely punctate, mottled yellow and orange-brown pronotum.

Description. Female. Color. Vertex yellow; dorsal margin black; black longitudinal maculae laterad of midline and mesad of eye; black macula along ventral margin; black macula ventromedial of ocellus; reddish macula ventrad of ventrolateral carina; frontoclypeus with arcuate dorsal black macula, sutures and apex black; gena black. Pronotum mottled yellow and orange-brown, punctures orange-brown; metopidium with medial black macula extending to imaginary transverse line between humeral angles; three black supraocular maculate laterad of median carina; dorsal orange-brown macula extending from transverse imaginary line between humeral angles to posterior margin; lateral margin with brown-black macula from humeral angle nearly reaching posterolateral projection; scutellum base yellow with brown margins, 2 ovate brown maculae, and 2 longitudinal maculae extending from mid-dorsal to posterior margin; apex pale yellow. Forewing basal sclerotization brown with black punctures and yellow macula on vein R; membrane fuscous, faint transverse macula at distal edge of sclerotization between costal margin and vein $\mathrm{M}$, faint macula from costal margin to commisural margin just basad of $r-m_{1}$, commisural margin black basally; veins dark. Legs: femora redbrown with black lateral macula, yellow maculae ventrally and 
on dorsal apex; tibiae pale brown with dark brown basal macula, apex pale yellow; tarsi brown, tarsomere III with basal twothirds yellow. Head. Vertex clothed with short, thick, white setae; dorsomedial surface flat; ventrolateral carina indistinct. Thorax. Pronotum covered with short, thick, white setae; ventral postocular keel absent. Scutellum (Figs 56-57) base slightly inflated; apex punctate, posterior midline carinate. Forewing crossvein s even with distal r-m crossvein. Legs: metathoracic trochanter with 2 spines; spine I large and recurved, spine II weakly developed. Furcasternum with small, rounded anterior lobes. Abdomen. Terga with conspicuous pits; sternite III medial keel absent; pygofer with conspicuous pits dorsally (Fig. 111). Second valvulae width more or less uniform throughout; irregularly dentate dorsally (Fig. 112).

Male. Unknown.

Measurements (mm). Female. Body length 6.1-6.3; head width 2.9-3.0; pronotal width 2.8-2.9; forewing length 5.2-5.5.

Material examined. Holotype female: "ECUADOR: Napo, Tran-/ sect Ent. $1 \mathrm{~km} \mathrm{~S}$ Onkonegare/ Camp. Reserva Etnica Waorani/ 00³9'10"S, 076²6'00"W; 9-Oct-1994, T.L. Erwin,/ et. al., fogging, terre firme/ forest, lot\#911; Albertson Research/ NIC-0360 \%; Holotype/ Nicomia/ harenosa/ Albertson" [USNM]. Paratypes: 2 females, same data (Albertson Research NIC-0348, 0351) [USNM].

Distribution. EcuAdor: Napo. Collection date: October.

Notes. The name 'harenosa' is Latin for "sandy" and refers to the coarse texture of the pronotum.

\section{Nicomia inscripta Albertson, sp. nov. Figs 58-59, 80, 87-89, 113-114} [USNM].

Type locality. Cerro de la Neblina, Amazonas, Venezuela

Diagnosis. This species differs from other Nicomia in having abdominal terga with conspicuous pits and the aedeagus broad in lateral view and strongly compressed in ventral view, with 1 pair of apical triangular processes.

Description. Color. Vertex yellow; dorsal margin from eye to above ocellus black; orange maculae laterad of midline and dorsomesad of ocellus; black maculae surrounding ocellus; black maculae ventrolaterad of ocellus; frontoclypeus yellow with trapezoidal black macula, black medially; gena black. Pronotum yellow, punctures concolorous with adjacent areas except dorsum with darker punctures; maculae black or red-brown; median carina black on metopidium; black supraocular callosity dorsad of vertex dorsal process; red-brown macula from anterior margin above eye extending to humeral angle; black dorsal ovate macula; black lateral margins from humeral angle to posterolateral projection; red-brown posterior irregular maculae; scutellum base red or black with yellow maculae, pale yellow posteriorly. Forewing basal sclerotization black with anal veins yellow; membrane hyaline, fuscous macula present in female, absent or indistinct in male, veins orange-brown. Legs: femora orange-brown with yellow venter, apex pale; tibiae pale orange with preapical macula and apex yellow; tarsi yellow with apex of third tarsomere orange to brown. Head. Vertex covered with long white setae with few dark setae near eyes; dorsomedial surface flat; ventrolateral carina indistinct; frontoclypeus covered with long white setae. Thorax. Pronotum covered with long, white setae; ventral postocular keel absent. Scutellum (Figs 5859 ) base slightly inflated, with long white setae; apex punctate, posterior midline with medial groove indistinct. Forewing $s$ crossvein basad of distal r-m crossvein. Legs: metathoracic trochanter with 3 spines; spine I largest, spines I and II recurved, spine III weakly developed. Furcasternum with small, rounded anterior and posterior lobes. Abdomen. Terga with conspicuous pits; pygofer with conspicuous pits dorsally. Male. Sternite VIII with anterior carina; posterior margin with well developed keeled projection. Pygofer with anterior carina absent dorsally (Fig. 80); lateral plate digitiform (Fig. 87); subgenital plate lobes completely fused, with sub-basal constriction, apical two-thirds with lateral margins parallel, uniformly sclerotized without distinct fenestra. Aedeagus (Figs 88-89) posterior arm straight; shaft broad in lateral view and strongly compressed in ventral view; apex narrow, with pair of triangular processes; gonopore on ventral preapical surface. Connective anterior margin weakly emarginate, apices acuminate; posterior apex produced into short arm. Style apodeme short and straight (Fig. 89); shank with abrupt lateral bend preapically, dorsoventrally broadened in lateral view; apex bent and blade-like. Female. Second valvulae (Fig. 114) with dorsal margin more or less evenly arcuate throughout; uniformly dentate dorsally.

Measurements (mm). male/female. Body length 6.4/8.0; head width $3.3 / 3.5$; pronotal width $3.0 / 3.2$; forewing length 5.3/6.5.

Material examined. Holotype male: "VENEZUELA: T.F.Amaz./ Cerro de la Neblina/ Basecamp, 140 m./ 050’ N, 66º' $10^{\prime}$ W/ 21-28 February 1985; P.J. \& P.M. Spangler/ R. A. Faitoute/ W. E. Steiner/ collectors; Membracoidea/ Phylogeny. NCARS/ Proj. \#NC 03979; CHD Research/ \# 98-0008; Albertson Research/ NIC-0122 ơ; Holotype/ Nicomia/ inscripta/ Albertson" [USNM]. Paratype female, Venezuela, Amazonas, Basecamp, Cerro de la Neblina, $0^{\circ} 51^{\prime} \mathrm{N}, 66^{\circ} / 10^{\prime} \mathrm{W}, 140 \mathrm{~m}, 20-24$ March 1984 , O. Flint \& J. Louton (Albertson Research NIC-0356 female) [USNM].

Distribution. Venezuela: Amazonas. Collection dates: February to March.

Notes. The name 'inscripta' is Latin for "inscribe" and refers to the markings on the pronotum.

\section{Nicomia interrupta Stål, 1858 Figs 60-61, 84-86, 115-116}

Nicomia interrupta Stål, 1858: 249.

Hoplophera [sic] cicadoides Walker, 1862: 317. Syn. nov.

Type locality. Brazil [NRS].

Diagnosis. This species differs from other Nicomia in having the abdominal terga with conspicuous pits and a pair

Revista Brasileira de Zoologia 22 (1): 231-283, março 2005 


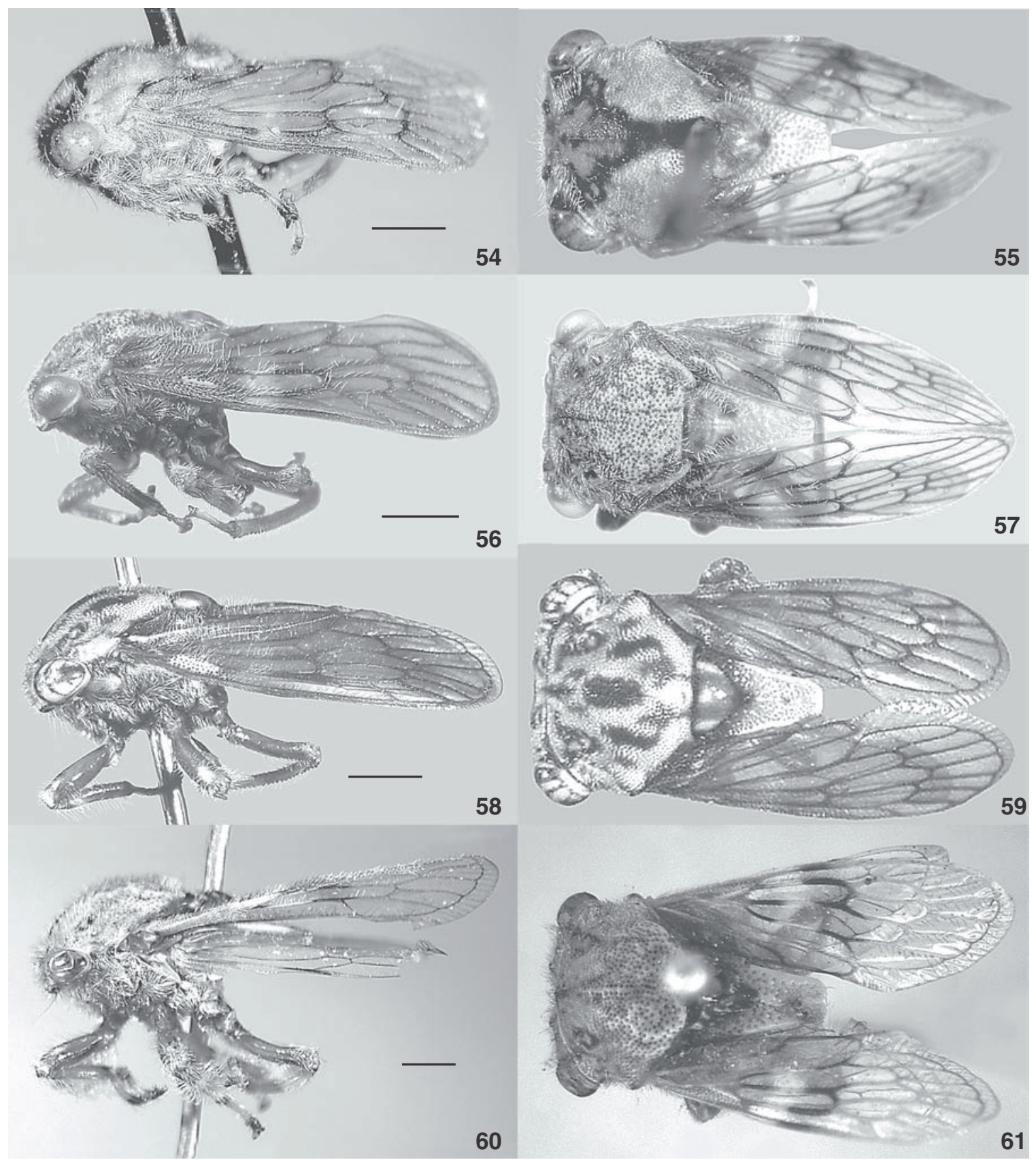

Figures 54-61. Nicomia adult lateral and dorsal habitus. (54-55) N. buccina holotype male; (56-57) N. harenosa holotype female; (5859) N. inscripta holotype male; (60-61) N. interrupta, holotype female.

of large, style-like processes arising from the base of the aedeagus.

Description. Color. Vertex yellow; dorsal processes black; median longitudinal macula and V-shaped macula ventrolaterad of ocellus black; frontoclypeus black medially, with red-brown swelling near apex; gena black. Pronotum pale yellow, punctures concolorous with adjacent areas; metopidium with median carina black; maculae laterad of median carina and dorsad of vertex dorsal processes black; lateral margin from humeral angle to posterolateral projection dark red-orange; circular median posterior macula black; scutellum base dark red-orange to black with three large yellow maculae anteriorly

Revista Brasileira de Zoologia 22 (1): 231-283, março 2005 
and numerous small, irregular yellow maculae posteriorly; apex yellow with red-orange medial macula on basal two-thirds. Forewing basal sclerotization brown with yellow macula at base of anal fold; membrane hyaline, with broad transverse fuscous macula extending from costal margin near $\mathrm{R}_{1}$ to commisural margin near $\mathrm{Cu}_{1}$; veins brown with pale area of vein $\mathrm{R}$ adjacent to sclerotization, pale areas of veins $\mathrm{R}, \mathrm{M}$, and $\mathrm{Cu}$ just basad of macula. Legs: femora black dorsally, red-orange laterally, and yellow ventrally; tibiae with alternating transverse stripes of yellow and red-orange; tarsi yellow, base of tarsomere I and apex of tarsomere III red-brown. Head. Vertex setae long, white to pale brown; dorsal processes distinct; dorsomedial surface distinctly concave; ventrolateral carina distinct. Thorax. Pronotum setae long and white near vertex, darker and shorter dorsally; ventral postocular keel absent. Scutellum (Figs 60-61) base slightly inflated, with long white setae laterally; apex punctate, with short dark setae, posterior midline carinate. Forewing veins with long dark setae, setae white in pale areas of veins; s crossvein basad of distal r-m crossvein. Legs: metathoracic trochanter with 3 spines; spines I and II large and recurved, spine III weakly developed. Furcasternum with anterior and posterior lobes. Abdomen. Terga with conspicuous pits; sternite III with weak medial keel; pygofer without conspicuous pits dorsally. Male. Sternite VIII with anterior carina; posterior margin with well developed keeled projection. Pygofer without anterior carina dorsally; lateral plate digitiform with ventral process (Fig. 84); sternite IX anterior margin straight; subgenital plate lobes completely fused, with sub-basal constriction, apical two-thirds with lateral margins parallel, with densely sclerotized ridge and medial basal fenestra. Aedeagus (Figs 85-86) posterior arm enlarged at base; shaft tubular; pair of style-like lateral processes arising at base, gradually extending posterolaterally to point nearly even with apex of shaft; apex narrow, with one pair of small triangular processes; gonopore on ventral preapical surface. Connective broadly bilobed anteriorly; posterior margin truncate. Style (Figs 86-86) apodeme longer than shank, gradually extending laterally with apex abruptly bent posteriorly; shank only slightly curved laterally; apex bent and blade-like. Female. Second valvulae with dorsal margin distinctly angulate; uniformly dentate dorsally (Fig. 116).

Measurements (mm). male/female. Body length 5.2/8.0; head width $2.2 / 2.5$; pronotal width $2.1 / 2.4$; forewing length 4.0/6.6.

Material examined. Holotype female, Nicomia interrupta Stål: "Brasil; F. Sahlb.; Typus; Albertson Research/ NIC-0992 [NRS]. Holotype male, Hoplophera [sic] cicadoides Walker: "Type; Rio; Hoplophora/ cicadoides [illegible]; Miss Pascoe/ 96-41.; Albertson Research/ NIC-1010 ơ" [BMNH].

Distribution. BrazIL: Rio de Janeiro. Collection date: unknown.

Notes. Nicomia cicadoides (Walker) is here considered a junior synonym of Nicomia interrupta Stål based on compari- son of the type specimens. The holotype of Nicomia interrupta is a female and the holotype of Nicomia cicadoides is male. Walker's (1862) description of Hoplophera [sic] cicadoides mistakenly lists the type specimen as female.

\section{Nicomia jucunda Albertson, sp. nov. Figs 62-63, 90-92, 117-118}

Type locality. Antécume Pata, Saint-Laurent du Maroni, French Guiana [MNHN].

Diagnosis. This species differs from other Nicomia in having abdominal terga with conspicuous pits, a spine on the metathoracic coxa, and the aedeagus broad in lateral view and strongly compressed in ventral view, with a dorsal sub-basal hump, and lacking processes or flanges.

Description. Color. Vertex dark yellow; black macula extending from dorsal margin, through ocellus, to ventral margin; dorsolateral corner black; frontoclypeus yellow with red to black dorsal margin, dorsal arcuate macula, and sutures; gena yellow with black apex. Pronotum yellow, punctures concolorous with adjacent areas; metopidium with black median carina; triangular macula dorsomesad of eye black; V-shaped supraocular callosity brown; dorsum with black irregularly branched macula; humeral angle with oblique black stripe, lateral margin from humeral angle to posterior margin black, fading to dark brown; scutellum base dark yellow; faint basal transverse, median longitudinal, and short lateral maculae red-brown; apex pale yellow. Forewing basal sclerotization glossy black with yellow macula on base of first anal vein; macula between anal fold and first anal vein red-brown; membrane hyaline; veins dark with pale basal areas of veins $\mathrm{R}$ and M. Legs: prothoracic femur black, meso- and metathoracic femora black dorsally, brown laterally, and yellow ventrally; tibiae dark brown basally, pro- and mesothoracic tibiae yellow with brown transverse maculae, metathoracic tibia yellow with red-brown longitudinal macula; tarsi dark brown. The coloration of female differs as follows: frontoclypeus yellow with red sutures; maculae on metopidium and dorsal pronotum continuous, elongate maculae near posterior margin; scutellum base orange-red with anterolateral corners yellow; forewing membrane with fuscous transverse macula present. Head. Vertex covered with long white setae, brown setae near eyes; dorsomedial surface flat; ventrolateral carina distinct; frontoclypeus with long white setae. Thorax. Pronotum with mix of dark and white setae dorsally, white setae laterally; ventral postocular keel absent. Scutellum (Figs 62-63) base slightly inflated; apex punctate, posterior midline medial groove indistinct. Forewing s crossvein basad of distal r-m crossvein. Legs: metathoracic coxa with spine; trochanter with 4 spines, spines I and II large and recurved, spine III weakly developed; tibia with 2 to 3 cucullate setae in row I. Furcasternum with small, rounded anterior lobes. Abdomen. Terga with conspicuous pits; sternite III with weak medial keel; pygofer without conspicuous pits dorsally. Male. Sternite VIII with anterior carina; posterior margin with weak keeled projection. Pygofer without 


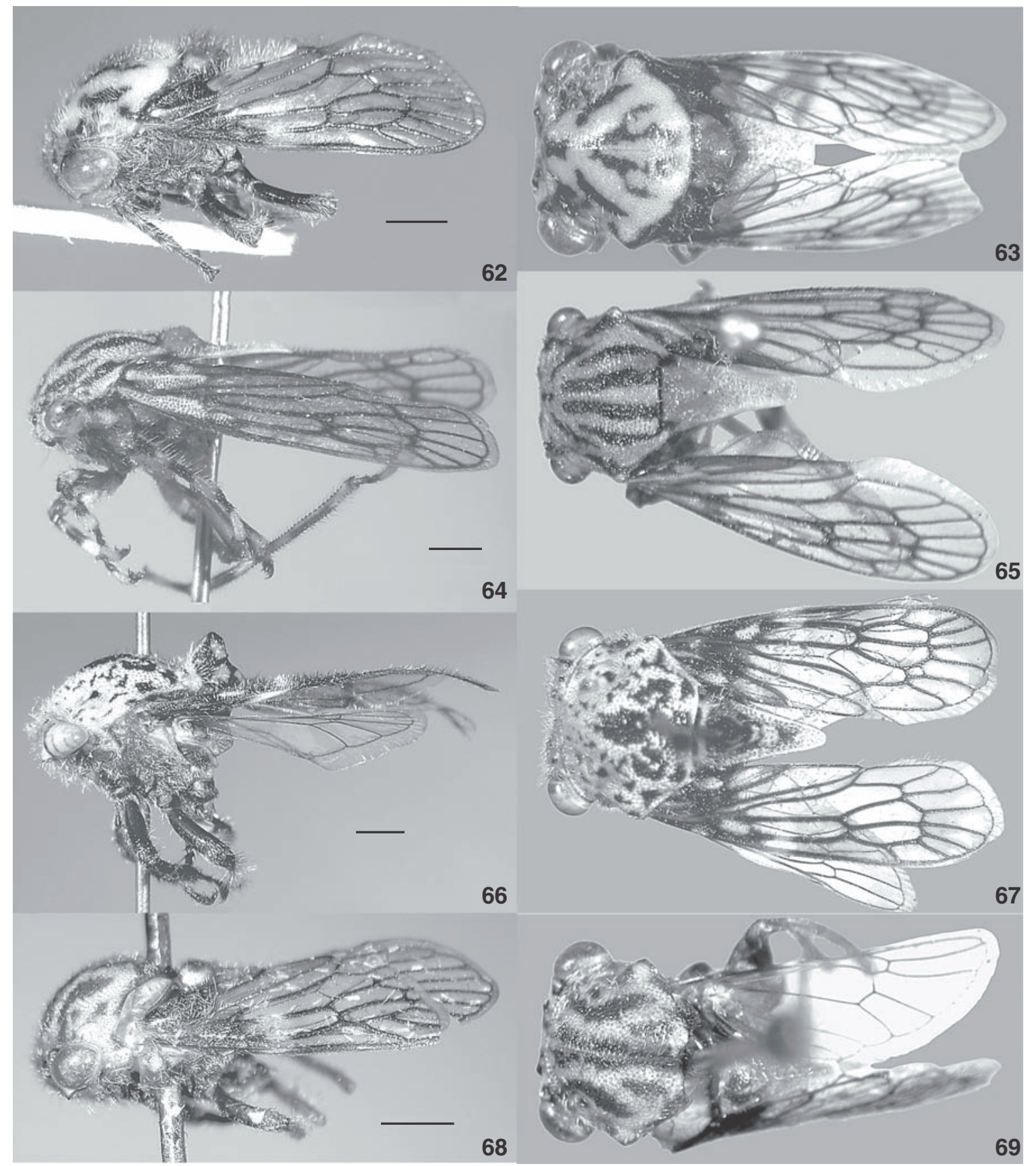

Figures 62-69. Nicomia adult lateral and dorsal habitus. (62-63) N. jucunda holotype male; (64-65) N. lemniscata, holotype female; (6667) N. monticola holotype male; (68-69) N. nigrifasciata holotype male.

anterior carina dorsally; lateral plate digitiform (Fig. 90); sternite IX anterior margin straight; subgenital plate lobes completely fused, with subbasal constriction, apical two-thirds with lateral margins parallel, with densely sclerotized lateral ridge (with setae) and median basal fenestra (glabrous). Aedeagus (Figs 91-92) posterior arm straight; shaft broad in lateral view and strongly compressed in ventral view, dorsal sub-basal hump; apex narrow, processes absent; gonopore on ventral preapical surface. Connective anterior margin weakly emarginate, apices acuminate; posterior apex produced into short arm. Style (Figs 91-92) 
apodeme short and straight; shank straight with slight curve before apex in dorsal view; apex acute. Female. Second valvulae with dorsal margin distinctly angulate; uniformly dentate dorsally (Fig. 118).

Measurements (mm). male/female. Body length 7.0/7.6; head width 3.1/3.2; pronotal width $2.8 / 3.1$; forewing length 5.8/6.3.

Material examined. Holotype male: “ANTÉCUMEPATA [sic]/ (SAUT KIALO)/ 22-XI-1975; ITANI (GUYANES)/ Mission M. Boulard,/ P. Jauf[f]ret et P. Pompanon/ Muséum PARIS; Albertson Research/ NIC-0912 ơ; Holotype/ Nicomial jucunda/ Albertson" [MNHN]. Paratype female, BrazIL, Amazonas: $18.1 \mathrm{~km}$ E Campinas, field station $\mathrm{Km} 60 \mathrm{~N}$ Manaus, $02^{\circ} 30^{\prime} \mathrm{S} 060^{\circ} 15^{\prime} \mathrm{W}$, 22 February 1979, terra firme forest, canopy fogged with Pyrethrum, Sample \#5; Montgomery, Erwin, Schimmel, Krischnik, Date, Bacon (Albertson Research NIC-0361 female) [USNM].

Distribution. Brazil: Amazonas. French Guiana: SaintLaurent du Maroni. Collection dates: February and November. Notes. The name 'jucunda' is Latin for "delightful".

\section{Nicomia lemniscata Stål, 1858 Figs $64-65,119-120$}

Nicomia lemniscata Stål, 1858: 249.

Type locality. Rio de Janeiro, Brazil [NRS].

Diagnosis. This species differs from other Nicomia in having 4 dorsal longitudinal black maculae extending to the posterior margin of the pronotum, and the abdominal terga with conspicuous pits.

Description. Female. Color. Vertex dark yellow; maculae on dorsolateral corners and surrounding dorsal margin of ocellus black; ventral margin black; frontoclypeus dark yellow, black arcuate macula dorsally; gena yellow, apex red-black. Pronotum dark yellow, punctures concolorous with adjacent areas; metopidium with black medial macula; black diagonal sublateral macula; four black dorsal longitudinal maculae extending from imaginary line between humeral angles to posterior margin; black longitudinal macula extending from above eye to posterior margin of humeral angle; scutellum base red; apex pale yellow with dark yellow lateral and apical margins. Forewing basal sclerotization yellow; membrane hyaline; veins brown. Legs: femora red-brown dorsally, yellow macula ventrally and on dorsal apex; tibiae yellow with base, medial macula, and apex black; tarsi black, tarsomere III with basal two-thirds yellow. Head. Vertex with short, golden setae and dark setae near eye; dorsomedial surface flat; ventrolateral carina indistinct; frontoclypeus with long white setae. Thorax. Pronotum with short golden and black setae; ventral postocular keel absent. Scutellum (Figs 64-65) setae short, pale; base produced dorsally; apex punctate, posterior midline medial groove distinct. Forewing $\mathrm{s}$ crossvein even with distal $\mathrm{r}-\mathrm{m}$ crossvein. Legs: metathoracic trochanter with three spines; spine I recurved, spine III weakly developed; tibia with 4 to 5 weak cucullate setae in row I. Furcasternum with anterior and posterior lobes. Abdomen.
Terga with conspicuous pits; pygofer without conspicuous pits dorsally. Second valvulae with dorsal margin distinctly angulate; uniformly dentate dorsally (Fig. 120).

Male. Unknown.

Measurements (mm). Female. Body length 9.6; head width 3.7 ; pronotal width 3.7 ; forewing length 8.1 .

Material examined. Lectotype [female], here designated, labeled: "F. Sahlb.; 76 / 83; Typus; Riksmuseum/ Stockholm; Rio Jan.; LECTOTYPE/ Nicomia/ lemniscata/ Stal/ Deitz Research \#83209a[female]; Albertson Research/ NIC-0993 [female]" [NRS].

The specimen here designated as lectotype was labeled by L.L. Deitz, but he never published this designation.

Distribution. BraziL: Rio de Janeiro. Collection date: unknown.

Notes. The name 'lemniscata' is derived from the Latin word lemniscatus, meaning "beribboned," presumably referring to the black stripes on the pronotum.

\section{Nicomia monticola Albertson, sp. nov. Figs $66-67,93-95$}

Type locality. Rio de Janeiro (Corcovado), Rio de Janeiro, Brazil [UFPC].

Diagnosis. This species differs from other Nicomia in its large size, the keeled scutellum, abdominal terga with conspicuous pits absent, and the aedeagus broad in lateral view and strongly compressed in ventral view, with an apical flange.

Description. Male. Color. Vertex dark yellow; small macula around medial margin of ocellus black; maculae on dorsal process, on dorsolateral corners, near midline, and at ventrolateral corners black; frontoclypeus with small black arcuate maculae, sutures and apex black; gena red-brown with apex black. Pronotum yellow, punctures concolorous with adjacent areas except black posteriorly; irregularly marked with numerous black maculae; scutellum base with 2 black depressions on anterior margin, anterior face of keel orange, keel black with orange maculae; apex yellow with brown medial U-shaped macula. Forewing basal sclerotization dark brown to black with orange macula on base of vein $\mathrm{R}$ and medial second anal vein, yellow macula at base of first anal vein; membrane hyaline, faint fuscous transverse macula between costal margin and vein $\mathrm{M}$; veins dark with pale area on marginal vein and vein $\mathrm{R}$ basad of macula. Legs: prothoracic leg black; meso- and metathoracic femora black with yellow ventromedial macula; tibiae yellow with base and apex black; tarsi black. Head. Vertex with long white setae; dorsomedial surface distinctly concave; ventrolateral carina indistinct; frontoclypeus with long white setae. Thorax. Pronotum with short white setae and scattered dark setae; ventral postocular keel well developed. Scutellum (Figs 66-67) base acutely produced dorsally; keel present, covered with long dark setae, lateral areas with pale setae; apex punctate with pale setae, posterior midline carinate. Forewing s crossvein basad of distal r-m crossvein. Legs: metathoracic trochanter with 4 spines, spines I and II large and recurved, spines III and IV weakly developed.

Revista Brasileira de Zoologia 22 (1): 231-283, março 2005 
Furcasternum with anterior lobes. Abdomen. Terga without conspicuous pits; sternite III with weak medial keel. Sternite VIII anterior carina absent; posterior margin with weak keeled projection. Pygofer without anterior carina dorsally; lateral plate robust (Fig. 93); sternite IX anterior margin straight; subgenital plates incompletely fused, with sub-basal constriction, apical two-thirds tapering, uniformly sclerotized without distinct fenestra. Aedeagus (Figs 94-95) posterior arm straight; shaft broad in lateral view and strongly compressed in ventral view; apex narrow, processes absent; serrate flange surrounding apex and extending partially along distal shaft; gonopore on ventral preapical surface. Connective anterior margin weakly emarginate and broadly rounded; posterior apex produced into short arm. Style (Figs 94-95) apodeme gradually extending laterally, approximately equal in length to shank; shank in dorsal view with slight lateral curve before apex; apex bent and blade-like.

Female. Unknown.

Measurements (mm). Male. Body length 10.0; head width 4.2; pronotal width 4.1; forewing length 8.1.

Material examined. Holotype male: "BRASIL Rio de Janeiro/ D.F. CORCOVADO/ XII.1957/ Alvarenga e Seabra; Albertson Research/ NIC-0799 o ; Holotype/ Nicomia/ monticola/ Albertson" [UFPC].

Distribution. Brazil: Rio de Janeiro. Collection date: December.

Notes. The name 'monticola' is derived from the Latin word monticulus, translating as "little mountain," and refers to the scutellar keel.

\section{Nicomia nigrifasciata Albertson, sp. nov. Figs $68-69,96-98$}

Type locality. Nusagandi, San Blas, Panama [USNM].

Diagnosis. This species differs from other Nicomia in having abdominal terga with conspicuous pits, the male pygofer with a dorsal anterior carina, and the aedeagus broad in lateral view and strongly compressed in ventral view, with an apical flange.

Description. Male. Color. Vertex yellow; macula surrounding ocellus black; dorsomedial macula black; dorsolateral corners and venter black; frontoclypeus yellow with black dorsal arrow-shaped macula; gena red-brown with yellow and black maculae near apex. Pronotum yellow, punctures concolorous with adjacent areas; longitudinal red-brown macula laterad of midline extending from anterior margin to posterior margin, interrupted for short distance dorsally; red-brown supraocular callosity and irregular macula extending from dorsad of eye to near posterior margin; lateral margin from humeral angle to posterolateral projection black; scutellum base yellow with redbrown anterior transverse macula, 2 large red-brown maculae dorsally; apex pale yellow. Forewing basal sclerotization redbrown with yellow macula at base of vein $\mathrm{R}$, black macula at base of vein $\mathrm{M}+\mathrm{Cu}$, base of first anal vein yellow, black macula between anal fold and first anal vein at distal edge of sclerotization, black maculae near commisural margin at base and apex of second anal vein, yellow macula near apex of second anal vein; membrane hyaline with faint fuscous transverse macula extending from costal margin to vein $\mathrm{Cu}$; veins dark with pale areas on marginal, $\mathrm{R}, \mathrm{M}$, and $\mathrm{Cu}$ veins basad of macula. Legs: prothoracic femur red-brown, meso- and metathoracic femora red-brown with yellow macula ventrally; prothoracic tibia redbrown to black, meso- and metathoracic tibiae yellow with base red-brown. Head. Vertex with long white setae, darker setae near eyes and along ventral margin; dorsomedial surface flat; ventrolateral carina indistinct. Thorax. Pronotum with white setae, dark setae along posterior margin and on maculae; ventral postocular keel absent. Scutellum (Figs 68-69) base slightly inflated, with long dark and white setae, lateral areas and posterior with long pale setae; posterior punctate, posterior midline carinate. Forewing s crossvein distad of distal r-m crossvein. Legs: metathoracic trochanter with 2 spines, spines I and II recurved. Furcasternum with small anterior lobes. Abdomen. Terga with conspicuous pits; sternite III without medial keel; pygofer with conspicuous pits dorsally. Sternite VIII posterior margin with weak keeled projection. Pygofer with incomplete anterior carina dorsally, absent medially; lateral plate digitiform (Fig. 96), strongly curved medially, only just visible in dorsal view; sternite IX anterior margin emarginate medially; subgenital plate lobes completely fused, with subbasal constriction, apical two-thirds tapering, with densely sclerotized lateral ridge (with setae) and median basal fenestra (glabrous). Aedeagus (Figs 97-98) posterior arm straight; shaft broad in lateral view and strongly compressed in ventral view; apex narrow, processes absent; serrate flange surrounding apex and extending partially along distal shaft; gonopore on ventral preapical surface. Connective anterior margin weakly emarginate and broadly rounded; posterior apex truncate. Style (Figs 97-98) apodeme slightly shorter than shank, slightly curved laterad; shank gradually curving laterad in dorsal view; apex bent and blade-like.

Female. Unknown.

Measurements (mm). Male. Body length (broken, unmeasurable); head width 2.7; pronotal width 2.5 ; forewing length (broken, unmeasurable).

Material examined. Holotype male: "PANAMA: San Blas/ 2km. S Nusagandi/ 3 March 1985/ Flint \& Louton; Albertson Research/ NIC-0124 $\sigma^{\star}$; Holotype/ Nicomia/ nigrifasciata/ Albertson" [USNM].

Distribution. Panama: San Blas. Collection date: March.

Notes. The name 'nigrifasciata' is derived from the Latin words niger, meaning "black," and fascia, meaning "bands," and refers to the markings on the vertex.

\section{Nicomia notidana Albertson, sp. nov. Figs 70-71, 99-101}

Type locality. Parque Nacional do Jaú, Cachoeira, Amazonas, Brazil [INPA].

Diagnosis. This species differs from other Nicomia in having abdominal terga with conspicuous pits, the furcasternum 
with anterior lobes and multiple posterior lobes, and the aedeagus shaft tubular with one sub-apical dorsal process.

Description. Male. Color. Vertex yellow, punctures concolorous with adjacent areas; macula on dorsolateral corner and surrounding ocellus black; ventromedial corner brown with black maculae; ventral margin black; frontoclyeus pale yellow, with black arrow-shaped macula dorsally, apex black; gena reddish-brown with yellow dorsally. Pronotum yellow, punctures concolorous with adjacent areas except black dorsally; metopidium with black medial macula; supraocular callosities orange; margin of humeral angle black; medial black macula dorsally; with six longitudinal black maculae posteriorly; posterolateral corners brown. Scutellum base dark yellow with pair of longitudinal red-brown maculae medially, black apically; apex pale yellow. Forewing basal sclerotization yellow with black punctures on corium, red-brown with yellow veins on clavus; membrane hyaline; veins black with pale areas at distal edge of sclerotization and on $\mathrm{R}_{1}$ and $\mathrm{R}_{2}$. Legs: prothoracic femur black, meso- and metathoracic femora red-brown with pale yellow longitudinal macula ventrally, mesothoracic femur with dorsal pale yellow macula apically; pro- and mesothoracic tibiae red-brown to black with two transverse pale maculae, metathoracic femur red-brown, pale anteriorly, with pale yellow sub-basal and apical transverse maculae; tarsi brown to black, tarsomere III with basal two-thirds pale. Head. Vertex covered with short, pale setae and stout, black setae dorsally, mesad of ocellus, near eyes, and dorsad of frontoclypeus; dorsomedial surface flat; ventrolateral carina indistinct; frontoclypeus with short, pale setae. Thorax. Pronotum with intermixed black and pale short setae; ventral postocular keel absent. Scutellum (Figs 70-71) base slightly inflated, with black and pale long setae; apex punctate, with pale setae, posterior midline groove indistinct. Forewing veins with black and pale setae; s crossvein basad of distal r-m crossvein. Legs: metathoracic trochanter with 3 spines, spines I and II large and recurved, spine III short and straight. Furcasternum with lateral digitiform lobe and medial broad, irregular lobe anteriorly and 2 small lateral lobes, one recurved digitiform lobe, and broad, rounded medial lobe posteriorly. Abdomen. Terga with conspicuous pits; sternite III medial keel absent; pygofer with conspicuous pits dorsally. Sternite VIII anterior carina absent; posterior margin with well developed keeled projection. Pygofer without anterior carina dorsally; lateral plate (Fig. 99) length more than half length of subgenital plate, slender, more or less evenly tapered, apex rounded; sternite IX anterior margin convex; subgenital plate lobes incompletely fused, with sub-basal constriction, apical two-thirds with lateral margins parallel, uniformly sclerotized without distinct fenestra. Aedeagus (Figs 100-101) posterior arm straight; shaft tubular; with sub-apical triangular process dorsally; apex narrow, processes absent; gonopore on ventral preapical surface. Connective anterior margin straight; posterior apex truncate. Style (Figs 100-101) apodeme with apex curved slightly medially; shank straight; apex acute.
Female. Unknown.

Measurements (mm). Male. Body length 7.8; head width 3.7; pronotal width 3.2; forewing length 6.4.

Material examined. Holotype male: "BRASIL: Amazonas/ Par[que]Na[cional do] Jaú, Cachoeira,/ right margin Rio Jaú,/ $46 \mathrm{~m}$ asl PNJ009/ 01 ${ }^{\circ} 53^{\prime} 35^{\prime \prime}$ S, 61 41 41'47"W; 25-VI-2003/ light trap 7:30-8:30pm/ igapó D.M. Takiya; MEM013; Albertson Research/ NIC-1022 o $^{\prime \prime}$ [INPA].

Distribution. BRAzIL: Amazonas. Collection date: June.

Notes. The specific name 'notidana' is derived from the Greek word notidanos, meaning "with pointed dorsal fin" and refers to the single pointed dorsal process on the aedeagus.

\section{Nicomia pulchella Albertson, sp. nov. Figs 72-73, 78, 102-104, 121-122}

Type locality. Carbet Lavaud, Saint-Laurent du Maroni, French Guiana [MNHN].

Diagnosis. This species differs from other Nicomia in having an aedeagus sparsely clothed with setae, the abdominal terga with conspicuous pits, and the furcasternum with anterior and posterior lobes.

Description. Color. Vertex yellow; dorsolateral corners red-orange to black; circular macula dorsad of ocellus orange to red; macula surrounding medial margin of ocellus black; macula dorsad of frontoclypeus red-orange to red-brown; redorange to black ventrally; frontoclypeus yellow, dorsal triangular macula black, apex red-orange; gena red-orange with dorsal apex yellow, black longitudinal maculae along apex. Pronotum yellow, punctures concolorous with adjacent areas; metopidium ventral margin with black transverse macula medially and median carina black; several small black maculae laterad of midline; red-orange V-shaped supraocular callosity; longitudinal red-orange macula laterad of midline extending from dorsum to posterior margin, contiguous with lateral redbrown longitudinal macula; lateral margins from humeral angle to posterolateral projection black; scutellum base yellow, anterior margin with red-orange to black transverse macula, redorange longitudinal macula laterad of midline, black apically; apex pale yellow. Forewing basal sclerotization between costal margin and vein $\mathrm{R}+\mathrm{M}+\mathrm{Cu}$ yellow with red punctures, sclerotization on clavus dark red to red-brown with yellow macula at base of second anal vein; membrane hyaline with faint fuscous transverse maculae between vein $\mathrm{R}$ and $\mathrm{Cu}$, between costal margin and vein $\mathrm{M}$, and at apex of clavus, commisural margin dark brown to black; veins dark red-brown with pale areas on veins $\mathrm{R}$ and $\mathrm{M}$ basad of macula and at apex of first medial cell. Legs: femora pale red-orange with yellow venter; tibiae red-orange with yellow macula and apex; tarsi red-orange to brown, third tarsomere with basal two-thirds yellow. Coloration in female differs as follows: frontoclypeus yellow with black branched macula dorsally; gena red-orange; metopidium with numerous red-brown irregular maculae laterally; red-brown circular macula dorsally with red-brown punctures 


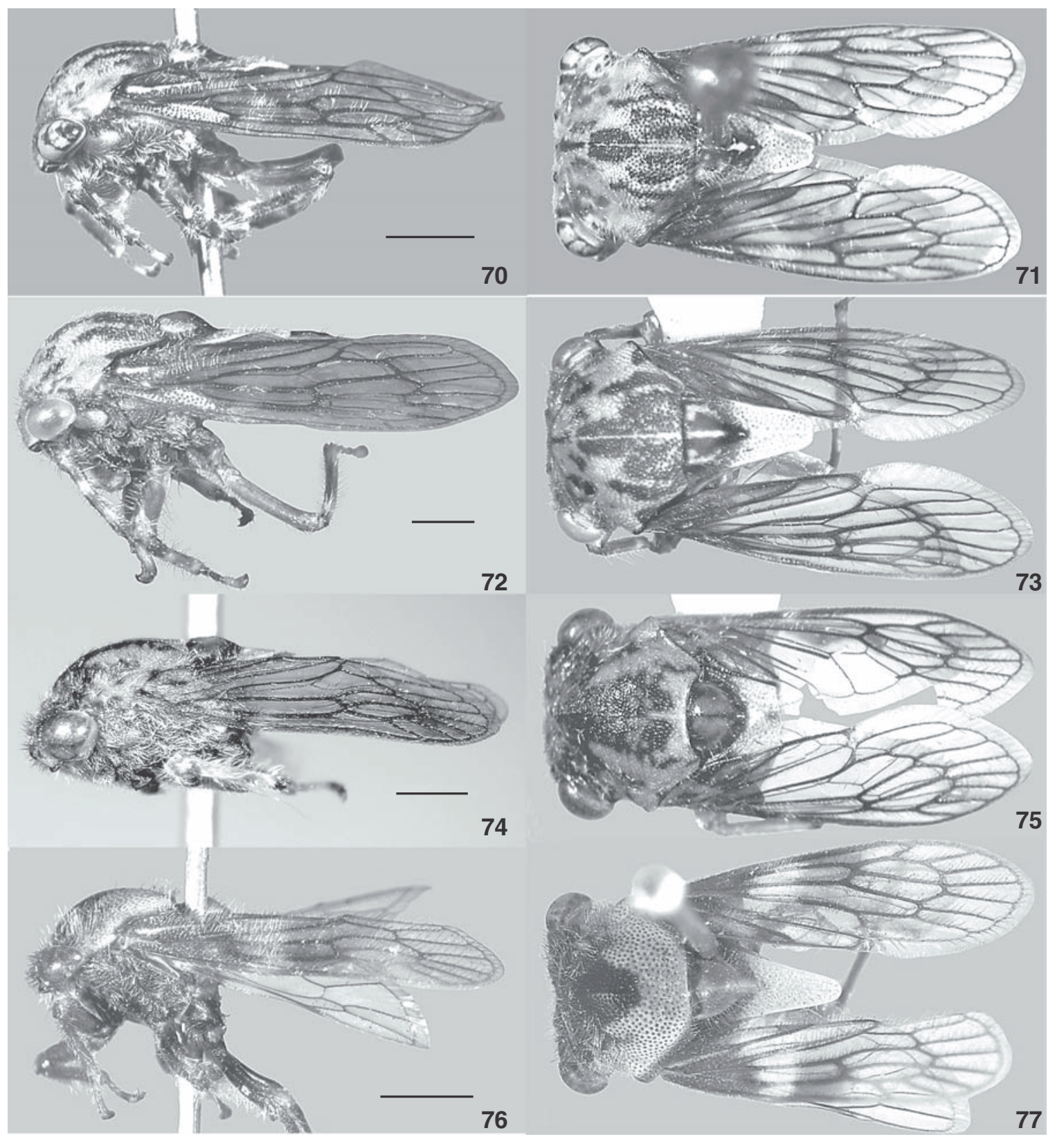

Figures 70-77. Nicomia adult lateral and dorsal habitus. (70-71) N. notidana holotype male; (72-73) N. pulchella holotype male; (74-75) N. serrata holotype male; (76-77) N. subfasciata sp. reval., holotype male.

on interior; inverted V-shaped red-brown macula posteriorly; two longitudinal red-brown maculae laterally, extending from dorsal pronotum to posterior margin; scutellum base yellow with anterior transverse black maculae, black longitudinal macula laterad of midline. Head. Vertex with short white setae, long dark setae near eye, dorsomedial margin, and along ventrolateral carina; dorsomedial surface flat; ventrolateral carina indistinct; frontoclypeus with long white setae. Thorax. Pronotum with mix of dark (especially along median carina dorsally) and white setae, short; ventral postocular keel absent. Scutellum (Figs 72-73) base produced dorsally, with long black setae dorsally, shorter white setae laterally; posterior punctate, with short white setae, posterior midline carinate. Forewing s crossvein basad of distal r-m crossvein. Legs: me-

Revista Brasileira de Zoologia 22 (1): 231-283, março 2005 

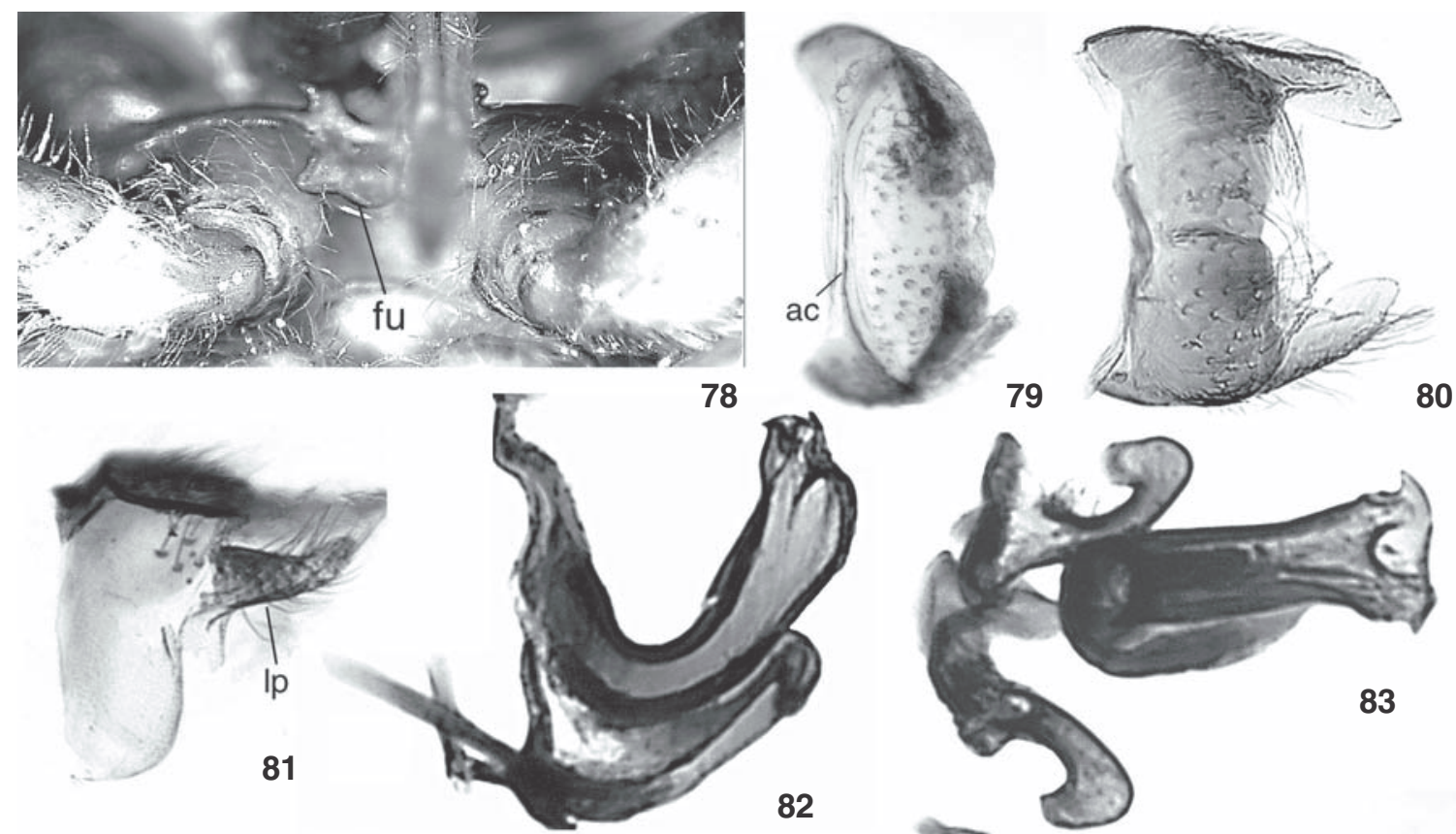

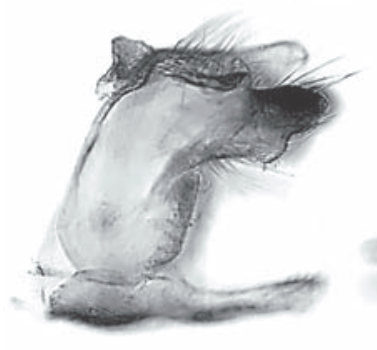

84

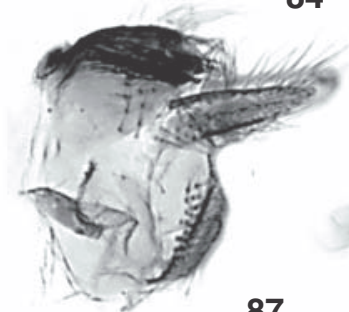

87

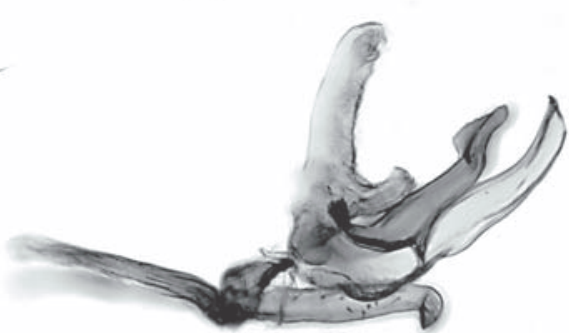

85

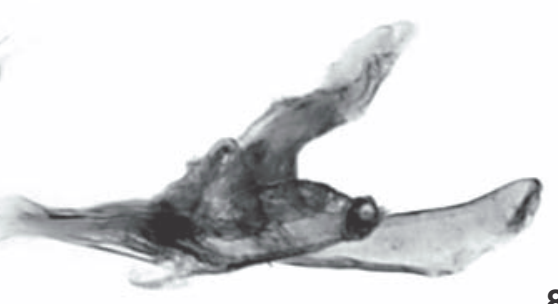

88

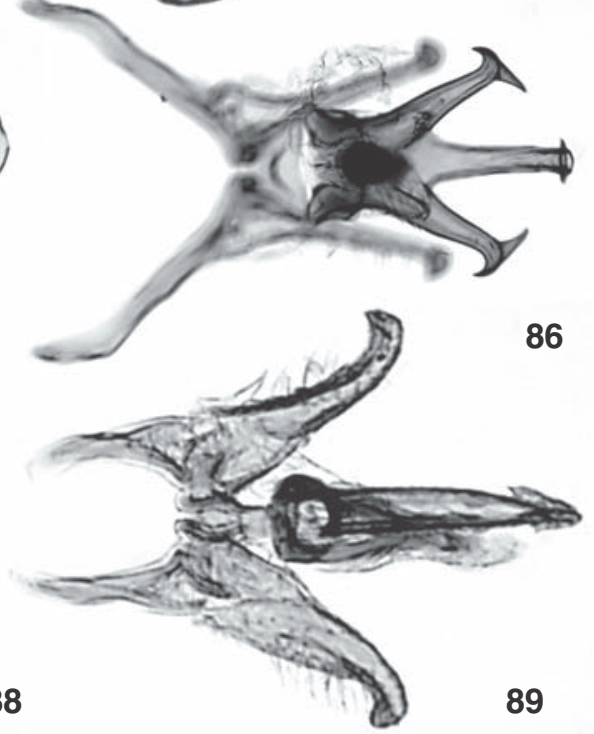

Figures 78-89. Nicomia. (78) N. pulchella paratype female, furcasternum; (79-80) male pygofer, dorsal view: (79) N. serrata, holotype; (80) Nicomia inscripta, holotype; (81-89) Nicomia males; (81-83) N. buccina holotype: (81) pygofer, lateral view; (82) genitalia, lateral view; (83) genitalia, posterior view; (84-86) N. cicadoides, holotype (junior synonym of N. interrupta): (84) genital capsule, lateral view; (85) genitalia, lateral view; (86) same, dorsal view; (87-89) N. inscripta holotype: (87) pygofer, lateral view; (88) genitalia, lateral view; (89) same, ventral view. (ac) Anterior carina, (fu) furcasternum, (lp) lateral plate.

sothoracic femur with 1 or 2 medial preapical cucullate setae dorsally in male; metathoracic trochanter with 3 spines, spines I and II recurved, spine III weakly developed. Furcasternum: male with short anterior lobe and rounded posterior lobe; female with short, laterally directed anterior lobe and large, broad posterior lobe with apical process directed laterally. Abdomen. Terga with conspicuous pits; sternite III without medial keel. Male. Sternite VIII posterior margin with weak keeled projection. Pygofer without anterior carina dorsally, with conspicuous pits; lateral plate robust (Fig. 102); sternite IX anterior 


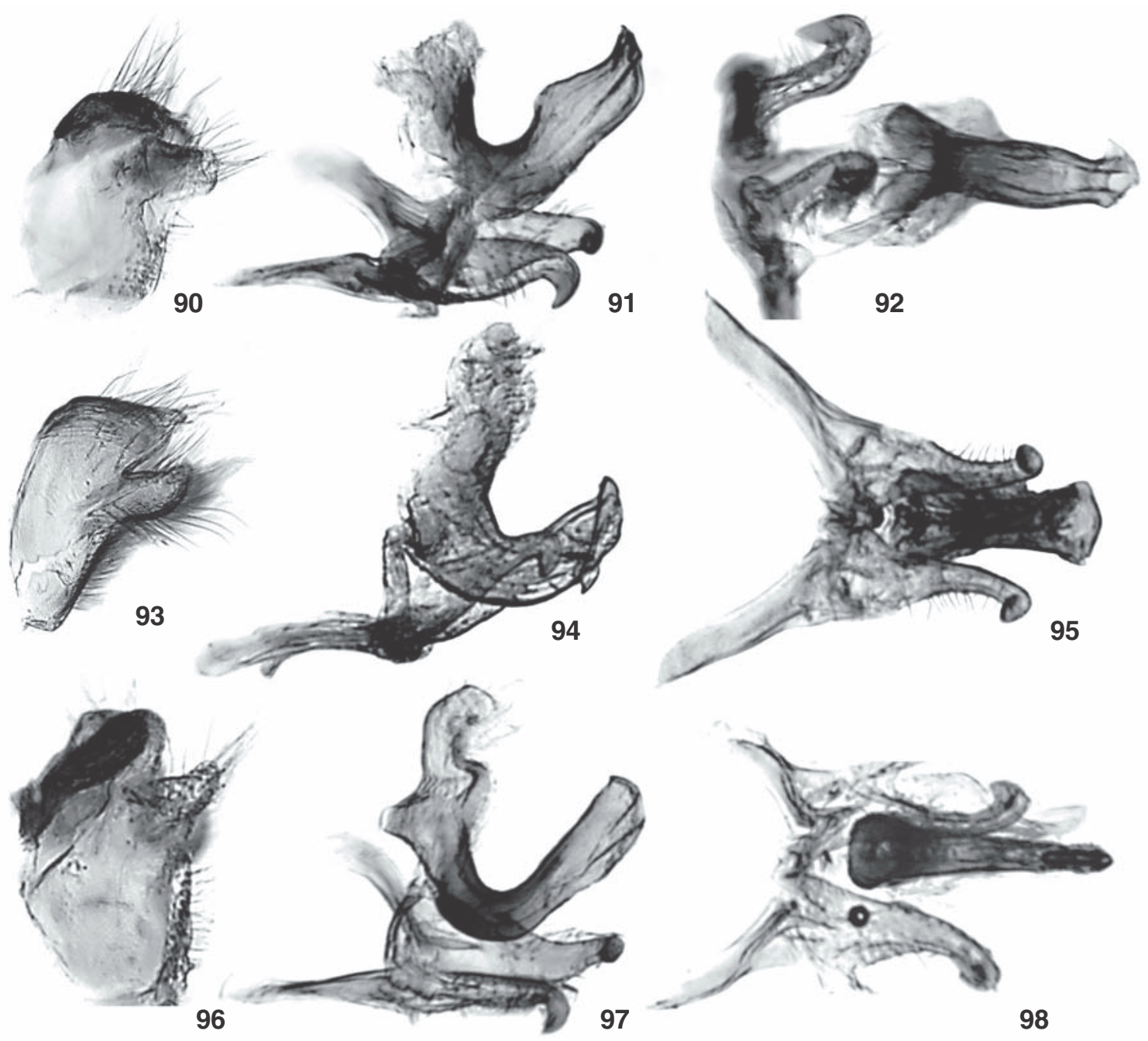

Figures 90-98. Nicomia males. (90-92) N. jucunda holotype: (90) pygofer, lateral view; (91) genitalia, lateral view; (92) same, posterior view; (93-95) N. monticola holotype: (93) pygofer, lateral view; (94) genitalia, lateral view; (95) same, ventral view; (96-98) N. nigrifasciata holotype: (96) pygofer, lateral view; (97) genitalia, lateral view; (98) same, ventral view.

margin emarginate medially; subgenital plate lobes completely fused, with sub-basal constriction, apical two-thirds with lateral margins parallel, uniformly sclerotized without distinct fenestra. Aedeagus (Figs 103-104) posterior arm straight; shaft tubular, with scattered setae; apex slightly enlarged compared to shaft, processes absent; gonopore on ventral preapical surface. Connective anterior margin weakly emarginate, apices acuminate; posterior apex broadly rounded. Style (Figs 103104) apodeme very short, straight; shank with gradual lateral curve near apex in dorsal view; apex acute. Female. Pygofer without conspicuous pits dorsally. Second valvulae with dorsal margin more or less evenly arcuate throughout; uniformly dentate dorsally (Fig. 122).

Measurements (mm). male/female. Body length 8.2/9.3; head width $3.6 / 4.1$; pronotal width $3.4 / 3.8$; forewing length 6.6/7.7.

Material examined. Holotype male: "CARBET LAVAUD/ (RIVE SURINAMIENNE)/ 3-4-XII-1975; ITANI (GUYANES)/ Mission M. Boulard,/ P. Jauf[f]ret et P. Pompanon/ Muséum PARIS; Albertson Research/ NIC-0910 ơ; Holotype/ Nicomia/ pulchella/ Albertson" [MNHN]. Paratype female, GuYANA: Essequibo, $39 \mathrm{mi}$. SW Wineperu, Mazaruni River 17-18 March 1969, Duckworth \& Deitz (Albertson Research NIC-0341 female) [USNM].

Distribution. French Guiana: Saint-Laurent du Maroni. GuYANA: Cuyuni-Mazaruni. Collection dates: March and December.

Notes. The name 'pulchella' translates from Latin as "pretty".

Revista Brasileira de Zoologia 22 (1): 231-283, março 2005 


\section{Nicomia serrata Albertson, sp. nov. Figs 74-75, 79, 105-107, 123-124}

Type locality. $18.1 \mathrm{~km}$ E Campinas field station, km 60 N Manaus, Amazonas, Brazil [USNM].

Diagnosis. This species differs from other Nicomia in having an aedeagus with a pair of dorsal, serrate flanges, the abdominal terga with conspicuous pits, and the male pygofer with a dorsal anterior carina.

Description. Color. Vertex dark yellow-orange, black ventrad of ventrolateral carina; dorsolateral corners black; macula surrounding ocellus and comma-shaped macula dorsomesad of ocellus red-orange to black; frontoclypeus black with yellow margins; gena red-brown with apex black. Pronotum mottled dark yellow-orange and red anteriorly and dorsally, pale green posteriorly, or yellow, punctures concolorous with adjacent areas; metopidium with black supraocular callosity; large black macula extending from anteromedial margin to near posterior margin; scutellum base dark orange with black anterior transverse macula, red-brown dorsal longitudinal stripe and lateral margins, black apically; apex pale yellow with bright yellow medial macula anteriorly, brown macula near midlength medially, pale green apically. Forewing basal sclerotization pale yellow with black area near apex of second anal vein; membrane hyaline with faint fuscous macula along vein $R_{2}$ and on hindwing below, commisural margin apex fuscous; veins dark with pale area near base of vein R. Legs: femora red-brown with black longitudinal macula anterolaterally, pale yellow macula ventrally and on dorsal apex; tibiae yellow with red-brown basal macula and sub-apical macula, apex dark brown to black; tarsi pale green with basal half of first tarsomere and apex of third tarsomere dark brown to black. Coloration of the female differs in the following aspects: frontoclypeus entirely yellow; pronotum redbrown medially and yellow laterally, metopidium with black macula extending from anterior margin above vertex dorsal process to mid-dorsally, posterior margin yellow medially; scutellum base red-brown. Head. Vertex with shorter white setae dorsally, long black setae ventral to ocelli; dorsomedial surface flat; ventrolateral carina distinct; frontoclypeus with long dark setae dorsal to transverse groove, long white setae below. Thorax. Pronotum covered with mix of short white and long dark setae; ventral postocular keel absent. Scutellum (Figs 74-75) base slightly inflated, with long golden setae; posterior punctate with darker setae, posterior midline medial groove indistinct. Forewing s crossvein distad of distal $r-m$ crossvein. Legs: metathoracic trochanter with 3 spines; spine I large and recurved. Furcasternum with short anterior lobes. Abdomen. Terga with conspicuous pits; sternite III with weak medial keel; pygofer with conspicuous pits dorsally. Male. Sternite VIII with anterior carina; posterior margin with well developed keeled projection. Pygofer with anterior carina dorsally (Fig. 75); lateral plate (Fig. 105) short, digitiform, strongly curved medially, only just visible in dorsal view; sternite IX anterior margin emarginate medially; subgenital plate lobes completely fused, with sub-basal constriction, apex broad and rounded, with densely sclerotized lateral ridge (with setae) and median basal fenestra (glabrous). Aedeagus (Figs 106-107) posterior arm straight; shaft tubular; apex narrow, processes absent; two serrate flanges extending lengthwise along dorsal shaft; gonopore on ventral preapical surface. Connective anterior margin strongly emarginate, apices diverging; posterior apex truncate. Style (Figs 106-107) apodeme short, extended anterolaterad; shank elongate, apex bent and blade-like. Female. Second valvulae broadened and angulate near midlength; uniformly dentate dorsally (Fig. 124).

Measurements (mm). male/female. Body length 6.7-7.6/ 7.8; head width 2.9-3.1/3.2; pronotal width 2.6-2.9/3.1; forewing length 5.5-5.9/7.0.

Material examined. Holotype male: "BRAZIL: AMAZONAS/ 18.1 km e Campinas/ field sta. Km 60/ n Manaus 22 Feb 1979/ 02 $30^{\circ}$ 'S $060^{\circ} 15^{\prime} \mathrm{W}$; Montgomery, Erwin,/ Schimmel, Krischik,/ Dat, Bacon colls.; Terra firme forest/ canopy fogged with/ Pyrethrum/ Sample \#23; Albertson Research/ NIC-0120 or; Holotype/ Nicomia/ serrata/ Albertson" [USNM]. Paratypes: 1 male, FrenCH GuiAnA, Saint-Laurent du Maroni: Carbet Lavaud, 24-26 November 1975; M. Boulard, P. Jauffret, P. Pompanon (Albertson Research NIC-0911 male) [MNHN], 1 male, same data, Wallace research \#01-2116 male (Albertson Research NIC-1015) [MNHN]; 1 female, Peru, Madre de Dios: Rio Tambopata Reserve, $30 \mathrm{~km}$ (air) SW Puerto Maldonado, $290 \mathrm{~m}, 12^{\circ} 50^{\prime} \mathrm{S}, 069^{\circ} 17^{\prime} \mathrm{W}$, Smithsonian Institution Canopy Fogging Project, T.L. Erwin, et al. 10 November 1983, 03/03 (Albertson Research NIC-0512 female) [USNM]; 1 male, Brazil, Amazonas: ParNa Jaú, Seringalzinho (Nazaré), right margin Rio Jaú, 46m, PNJ019, 01 52'55"S, 6135'12"W; 01 July 2003, light trap 7:30-8:30pm, terra firme, D.M. Takiya, MEM029 (Albertson Research NIC-1020 male) [INPA].

Distribution. Brazil: Amazonas. French Guiana: SaintLaurent du Maroni. Peru: Madre de Dios. Collection dates: February and November.

Notes. The name 'serrata' is Latin for "serrate" and refers to the serrate dorsal flange on the aedeagus.

\section{Nicomia subfasciata Stål, 1858, sp. reval.}

Figs 1, 7, 76-77, 108-110, 125-126

Nicomia subfasciata Stål, 1858: 249. Reinstated from synonymy.

Type locality. Brazil [NRS].

Diagnosis. This species differs from other Nicomia in having a large black macula on the metopidium, abdominal terga with conspicuous pits absent, and the aedeagus broad in lateral view and strongly compressed in ventral view, with an apical flange.

Description. Color. Vertex variable, ranging from entirely black to yellow with black maculae; frontoclypeus black, lateral margins yellow. Pronotum yellow with red-brown punctures; metopidium with black medial macula and red-brown supraocular callosity; pair of pale orange longitudinal maculae dorsally; lateral margin from humeral angle to posterolat-

Revista Brasileira de Zoologia 22 (1): 231-283, março 2005 


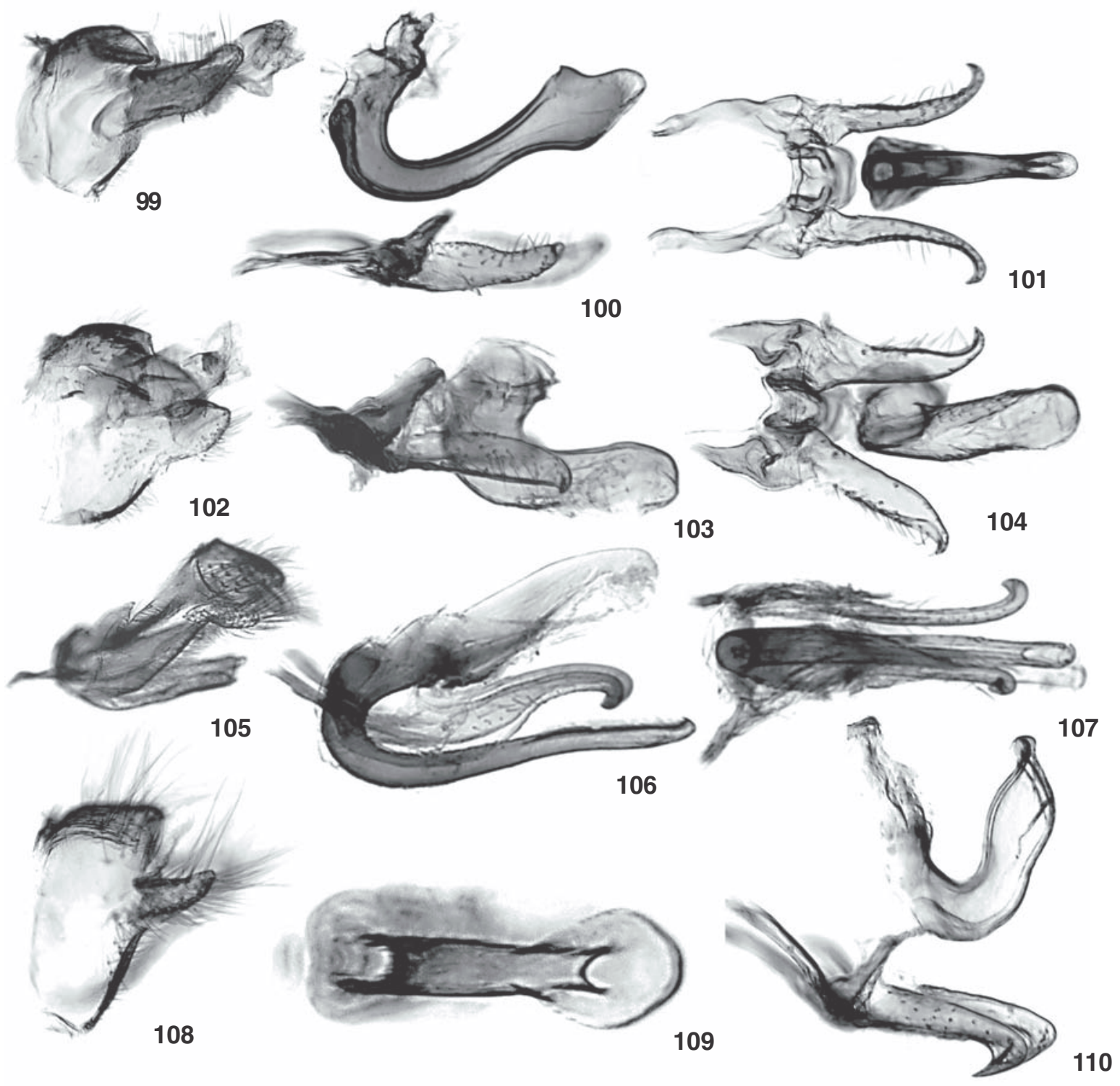

Figures 99-110. Nicomia males. (99-101) N. notidana holotype: (99) pygofer, lateral view; (100) genitalia, lateral view; (101) same, ventral view; (102-104) N. pulchella holotype: (102) pygofer, lateral view; (103) genitalia, lateral view; (104) same, ventral view; (105107) N. serrata holotype: (105) pygofer, lateral view; (106) genitalia, lateral view; (107) same, ventral view; (108-110) N. subfasciata sp. reval., holotype: (108) pygofer, lateral view; (109) genitalia, lateral view; (110) aedeagus, posterior view.

eral projection orange; scutellum base yellow with orangebrown dorsal longitudinal macula; apex pale yellow. Forewing basal sclerotization dark yellow-orange; membrane hyaline, faint fuscous transverse macula extending from costal margin to vein $\mathrm{M}$; veins pale brown with pale areas on costal margin, veins $\mathrm{R}$ and $\mathrm{M}$ basad of macula, and basal half of first anal vein, dark areas on veins $\mathrm{R}, \mathrm{M}$, and $\mathrm{Cu}$ distad of sclerotization and on veins $\mathrm{R}, \mathrm{M}, \mathrm{r}-\mathrm{m}_{1}$, and $\mathrm{Cu}$ distad of macula. Legs: femora dark red-brown at base and extending along lateral and ven- tral femur, pale red-brown dorsally, yellow macula on ventral base and apex; tibiae pale orange to yellow with faint maculae; tarsi yellow. Head. Vertex with long pale setae medially, long golden setae covering rest of vertex; dorsomedial surface flat; ventrolateral carina distinct; frontoclypeus with long white setae. Thorax. Pronotum with long pale setae, dark setae on maculae, white setae along entire anterior margin; ventral postocular keel absent. Scutellum (Figs 76-77) base slightly inflated, with long dark setae, lateral setae pale; posterior punctate with

Revista Brasileira de Zoologia 22 (1): 231-283, março 2005 


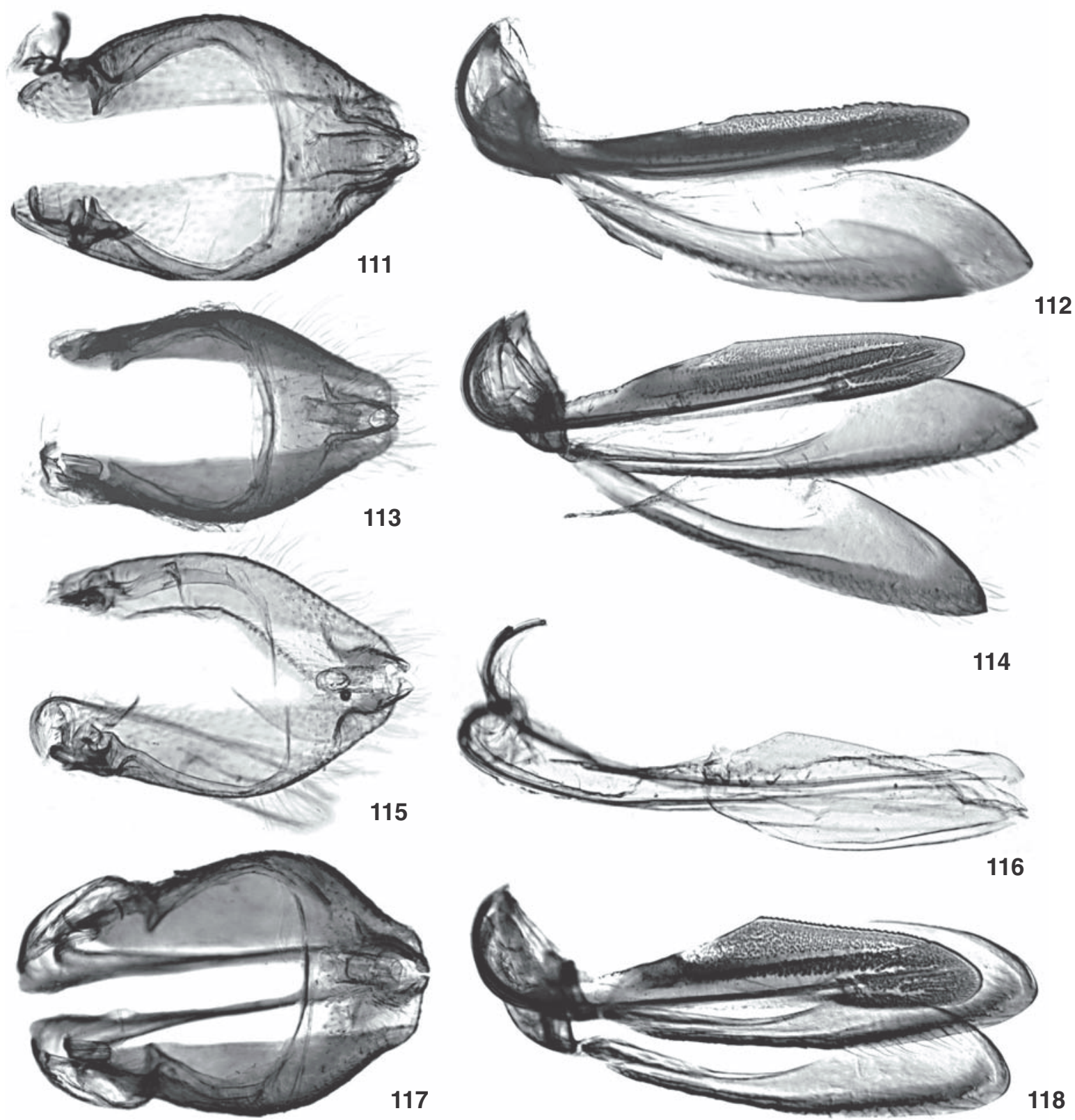

Figures 111-118. Nicomia females. (111-112) N. harenosa holotype: (111) pygofer, dorsal view; (112) second and third valvulae; (113114) N. inscripta paratype: (113) pygofer, dorsal view; (114) second and third valvulae; (115-116) N. interrupta holotype: (115) pygofer, dorsal view; (116) second and third valvulae; (117-118) N. jucunda paratype: (117) pygofer, dorsal view; (118) second and third valvulae.

long pale setae, posterior midline carinate. Forewing s crossvein basad of distal r-m crossvein. Legs: metathoracic trochanter with 4 spines, spine II largest, spines I and II recurved. Furcasternum with small anterior lobes. Abdomen. Terga without conspicuous pits; sternite III without medial keel. Male. Sternite VIII with anterior carina; posterior margin with weak keeled projection. Pygofer without anterior carina dorsally; lateral plate digitiform
(Fig. 108); sternite IX anterior margin straight; subgenital plate lobes incompletely fused, with subbasal constriction, apical twothirds tapering, uniformly sclerotized without distinct fenestra. Aedeagus (Figs 109-110) posterior arm straight; shaft broad in lateral view and strongly compressed in ventral view; apex narrow, processes absent; serrate flange surrounding apex and extending partially along distal shaft; gonopore on ventral

Revista Brasileira de Zoologia 22 (1): 231-283, março 2005 


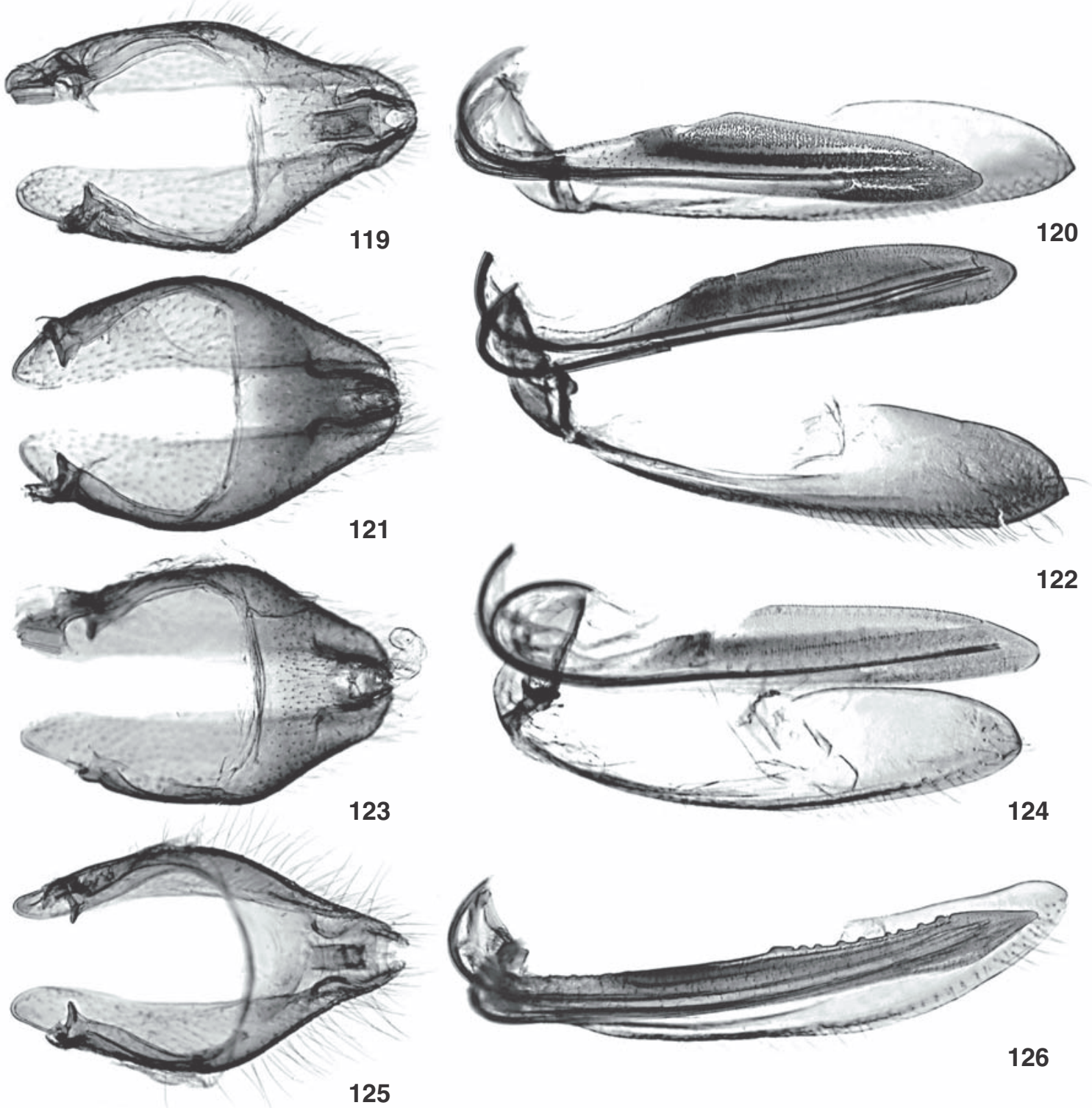

Figures 119-126. Nicomia females. (119-120) N. lemniscata holotype: (119) pygofer, dorsal view; (120) second and third valvulae; (121122) N. pulchella: (121) pygofer, dorsal view; (122) second and third valvulae; (123-124) N. serrata: (123) pygofer, dorsal view; (124) second and third valvulae; (125-126) N. subfasciata sp. reval.: (125) pygofer, dorsal view; (126) second and third valvulae.

preapical surface. Connective anterior margin straight; posterior apex truncate. Style (Figs 109-110) apodeme longer than shank, gradually extending laterally; shank straight with slight curve before apex in dorsal view; apex bent and blade-like. Female. Second valvulae of more or less uniform width throughout; irregularly dentate dorsally (Fig. 126).

Measurements (mm). male/female. Body length 6.0-7.8/ 8.4-8.5; head width 2.4-3.1/3.2-3.4; pronotal width 2.3-3.0/3.03.2; forewing length 4.9-6.2/7.1-7.2.

Revista Brasileira de Zoologia 22 (1): 231-283, março 2005
Material examined. Holotype male labeled: "Brasil; F. Salhb.; Typus; Albertson Research/ NIC-0994 $0^{\text {" }}$ [NRS]. Other material: 1 male, BraziL, Espírito Santo: Santa Teresa, 27 February 1964, C. Elias (Albertson Research NIC-0798 male) [UFPC]; 1 male, Santa Catarina: Seara, Nova Teutônia, $27^{\circ} 11^{\prime} \mathrm{B} 52^{\circ} 23^{\prime} \mathrm{L}$, F. Plaumann, 9 October 1976, 300-500 m (Albertson Research NIC-0797 male) [UFPC]; Rio de Janeiro, D.F. Corcovado, November 1958, Alvarenga and Seabra (Albertson Research NIC0796 male), 1 female same data except December 1957 (Albert- 
son Research NIC-0623) [UFPC]; Santa Catarina: Coleção Campos Seabra, December 1953, A. Maller (Albertson Research NIC0622 female) [UFPC]; Santa Catarina: Mafra, December 1930, A. Maller (Albertson Research NIC-0349 female) [NCSU]; 1 female [unknown South American locality] (Albertson Research NIC-0347 female) [NCSU].

Distribution. BraziL: Espírito Santo; Rio de Janeiro; Santa Catarina. Collection dates: February and October to November.

Notes. Nicomia subfasciata sp. reval., considered a junior synonym of Nicomia obliqua (Walker) by GodiNG (1927), is reinstated here based on examination of the type material. Nicomia obliqua is here transferred to the genus Tolania (see below). The name 'subfasciata' is derived from the Latin prefix sub-, meaning "below, under," and fasciata, meaning "bands, ribbons".

\section{Nodonica Dietrich, McKamey\& Deitz, 2001}

Nodonica Dietrich, McKamey\& Deitz, 2001: 227.

Type species: Nodonica bispinigera Dietrich, McKamey\& Deitz, 2001: 227, by original designation.

Diagnosis. Nodonica differs from other Nicomiinae in having the following combination of features: frontoclypeus convex but not produced ventrally with a transverse carina or fold; posterior pronotal process present, completely concealing scutellum; forewing with supranumerary crossveins; pro- and mesothoracic tibiae foliaceous; aedeagus shaft, in lateral view, U-shaped.

Description. Head. Head width less than the distance between pronotal humeri. Vertex width between eyes more than $2 \mathrm{x}$ height of vertex; dorsal processes closer to midline than to eyes; ocelli sessile; ventrolateral margins foliaceous. Frontoclypeus convex but not produced ventrally; transverse carina or fold present. Thorax. Distance from eye to wing base more than half eye width. Pronotum punctation dense; dorsal pubescence short; median carina strongly keeled, especially posteriorly; dorsal postocular keel well developed, ventral postocular keel absent; suprahumeral horns present as small tubercles; posterolateral projections absent; posterior process present, completely concealing scutellum (Fig. 11). Forewing supranumerary crossveins present; clavus apex acuminate; first and second anal veins free, second anal vein well developed. Metepimeron concealed by forewing at rest. Legs: prothoracic and mesothoracic tibiae foliaceous; mesothoracic femur with cucullate setae absent or only distal pair present; tibia with cucullate setal rows absent; metathoracic femur with distal pair cucullate setae dorsally; tibia with cucullate setal rows II and III present. Furcasternum reduced, without lobes. Male. Sternite VI width slightly wider than sternites VII and VIII; sternite VII length less than or equal to width; sternite VIII width more than $2 x$ length. Lateral plate more than half length of subgenital plate; sternite IX anterior margin emarginate medially; subgenital plates incompletely fused, uniformly sclerotized without distinct fenestra. Aedeagus shaft, in lateral view, U-shaped (Fig. 17). Female. Second valvulae width more or less uniform throughout; uniformly dentate dorsally.

Distribution. ECUADOR: Napo.

Notes. This genus was previously placed in the subfamily Centrodontinae by Dietrich et al. (2001). Wallace \& Deitz (2004) placed Centrodontini as a tribe of Centrotinae, but excluded Nodonica, treating the genus as incertae sedis within Membracidae. Cladistic analysis (see below) supports placement of Nodonica in Nicomiinae. Nodonica resembles other nicomiine genera in having cucullate setal rows II and III present on the metathoracic tibia, the aedeagus with apical processes, and supranumerary crossveins in the apical half of the forewing.

\section{Nodonica bispinigera Dietrich, McKamey\& Deitz, 2001} Figs 11,17

Nodonica bispinigera Dietrich, McKamey \& Deitz, 2001: 227.

Type locality. 1 km S Onkonegare, Napo, Ecuador [USNM].

Diagnosis. This species is distinguished by having a posterior pronotal process concealing the scutellum and two apical processes on the aedeagus.

Material examined. Holotype male: "ECUADOR: Napo, Tran-/ sect Ent. $1 \mathrm{~km} \mathrm{~S}$ Onkonegare/ Camp. Reserva Etnica Waorani/ 00³9'10"S, 076²6'00"W; 3-Jul-94 T.L. Erwin,/ et. al., fogging, terre firme/ forest, lot\#764; CHD Research/ \#980001; HOLOTYPE/ Nodonica/ bispinigera/ Dietrich, Deitz/ \& McKamey; Albertson Research/ NOD-1024 o" [USNM].

Distribution. Ecuador: Napo. Collection date: July.

Notes. This species was described and illustrated by Dietrich et al. (2001).

\section{Stalomia Albertson, gen. nov.}

Type species. Stalomia veruta Albertson, sp. nov.

Diagnosis. This genus differs from other Nicomiinae in having the following combination of features: frontoclypeus convex but not produced ventrally; forewing membrane with raised setae and $2 \mathrm{r}-\mathrm{m}$ crossveins; metathoracic tibia cucullate setal rows I, II, and III.

Description. Head. Vertex width between eyes more than $2 x$ height of vertex; dorsal processes conical and produced anteriorly, closer to eyes than to midline; ventrolateral margins carinate. Ocelli stalked. Frontoclypeus convex but not produced ventrally; transverse carina or fold absent. Distance from eye to wing base less than half eye width. Thorax. Distance from eye to wing base less than half eye width. Metopidium sloping, low; punctation dense; dorsal pubescence short and dense; median carina only slightly elevated; dorsal postocular keel absent; ventral postocular keel with carina not extended to apex; suprahumeral horns and tubercles absent; posterior margin straight, angulate laterally, posterolateral projections absent. Scutellum (Figs 127-128) base slightly inflated; apex truncate. Forewing (Fig. 3) vein R 4-branched, vein M 3-branched; crossvein s present distad of distal r-m crossvein; 2 r-m crossveins present, $r-m_{1}$ basad of $R_{1}$ and perpendicular to veins $R$ 
and $\mathrm{M}$; 1-2 m crossveins present; 1-2 m-cu crossveins, connected between first and second $\mathrm{M}$ fork; membrane with raised, stout setae; clavus with apex acuminate; veins $1 \mathrm{~A}$ and $2 \mathrm{~A}$ free, $2 \mathrm{~A}$ well developed. Metepimeron concealed by forewing at rest. Legs: pro- and meso- thoracic tibiae slender; mesothoracic femur with distal pair of cucullate setae dorsally; tibia without cucullate setal rows; metathoracic trochanter spines absent; femur with dorsal preapical cucullate setae; tibia with cucullate setal rows I, II, and III. Furcasternum reduced, without lobes. Abdomen. Terga without conspicuous pits; sternite III without medial keel. Male. Sternite VIII without anterior carina; posterior keeled projection absent. Female. Unknown.

Distribution. French Guiana: Cayenne.

Notes. The name Stalomia (feminine) combines the name of the author of Nicomia and Tolania with part of the name of the taxon (Nicomia) the new genus most closely resembles. This genus closely resembles Nicomia but is easily distinguished by the presence of cucullate setal row I on the metathoracic tibia, the anteriorly produced dorsal processes of the vertex, and the evenly tapered lateral margins of the male abdomen. The number of $\mathrm{s}, \mathrm{m}$, and $\mathrm{m}$-cu crossveins varies from one to two between the two forewings of the type specimen.

\section{Stalomia veruta Albertson, sp. nov.}

Figs 3, 127-133

Type locality. 41 km SE Roura, Cayenne, French Guiana. Diagnosis. This species is distinguished by the elongate posterior process on the male styles.

Description. Male. Color. Vertex yellow with red-brown punctures; maculae on dorsal margin, dorsal process, and medial margin of ocellus black; red-brown macula ventrally; frontoclypeus yellow; gena red. Pronotum pale yellow with red-brown punctures; metopidium with black macula laterad of medial carina; pair of elongate black maculae posteriorly; ventral postocular keel yellow; posterolateral and posterior margins black; scutellum base yellow with pair of red-brown maculae dorsally; apex yellow. Forewing basal sclerotization brown with yellow costal margin and anal veins, commisural margin black; membrane fuscous basally and hyaline distally, transverse preapical fuscous macula present; veins dark basally and pale distally. Legs: prothoracic femora yellow with black longitudinal macula dorsally, meso- and metathoracic femora yellow with black transverse preapical macula; tibiae yellow with red-brown to black transverse stripes; tarsi yellow. Head. Vertex dorsomedial surface distinctly concave; clothed in long, dark setae. Compound eyes elliptical. Thorax. Pronotum clothed in long, pale setae; metopidium coarsely punctate, appearing nearly rugose. Scutellum (Figs 127-128) base and apex punctate with short, pale setae; posterior midline medial groove distinct. Male. Lateral plate (Fig. 130) less than half length of subgenital plate, robust; sternite IX anterior margin straight; subgenital plate lobes incompletely fused, with apical twothirds tapering, uniformly sclerotized without distinct fenes- tra. Aedeagus (Figs 132-133) posterior arm nearly straight; tubular; apex narrow; processes absent; gonopore on ventral preapical surface. Connective anterior strongly emarginate, apices diverging; posterior apex broadly rounded. Style (Figs 132-133) shank gradually curving dorsally toward apex; apex more or less acute with long, slender process extending posteriorly.

Female. Unknown.

Measurements (mm). Male. Body length 6.1; head width 2.6; pronotal width 2.3; forewing length 5.3.

Material examined. Holotype male: "FRENCH GUIANA:/ 41 km SE Roura on/ Kaw Rd, 8-XII-2002/ J.E. Eger, coll; N04 $32.214^{\prime} /$ W052 $2^{\circ} 07.420^{\prime} / 272 \mathrm{~m}$ MV Light; FREYTAG; Albertson Research/ TOL-1016 male; Holotype/ Stalomia/ veruta/ Albertson" [UKY].

Distribution. French Guiana: Cayenne. Collection date: December.

Notes. The name 'veruta' is Latin for "armed with a javelin" and refers to the large, acute posterior process on the styles.

\section{Tolania Stål, 1858 \\ Figs 2, 2A, 8, 10}

Tolania Stål, 1858: 248.

Type species: Tolania semipellucida Stål, 1858, by original monotypy.

Diagnosis. Tolania differs from other Nicomiinae in having the frontoclypeus produced ventrally; suprahumeral horns usually present (but reduced or absent in some individuals or species); the forewing usually with $1 \mathrm{r}-\mathrm{m}$ crossvein (but 2 or more in some species); and the metathoracic tibia with cucullate setal rows I, II, and III.

Description. Head. Vertex width between eyes more or less than $2 \mathrm{x}$ height of vertex; dorsal processes closer to eyes than to midline; ventrolateral margins carinate or foliaceous; ocelli sessile or elevated. Frontoclypeus produced ventrally (Fig. 8); transverse carina or fold absent or present; median longitudinal carina absent or present; lateral lobes indistinct or fused to frontoclypeus, with or without distinct sutures. Thorax. Distance from eye to wing base less than half eye width. Pronotum metopidium weakly to strongly elevated; punctation sparse to dense; dorsal pubescence short to long, dense, or long and erect; dorsal postocular keel absent; median carina slightly elevated to weakly keeled and acute dorsally; suprahumeral horn development varying from absent to small tubercles to well developed (Fig. 8); posterior margin straight, angulate laterally, with posterolateral projections well developed. Scutellum apex narrow and rounded or acute. Forewing (Fig. 2) with 1 or $2 \mathrm{~s}$ crossveins usually distad of $\mathrm{r}-\mathrm{m}_{2} ; 1$ or $2 \mathrm{r}$ $\mathrm{m}$ crossveins present; $1 \mathrm{~m}$-cu crossvein connected basad of first $\mathrm{M}$ fork, or between first and second $\mathrm{M}$ fork; crossvein $\mathrm{m}$ absent or present; supranumerary crossveins present in one new species; clavus apex acuminate; first and second anal veins free, 


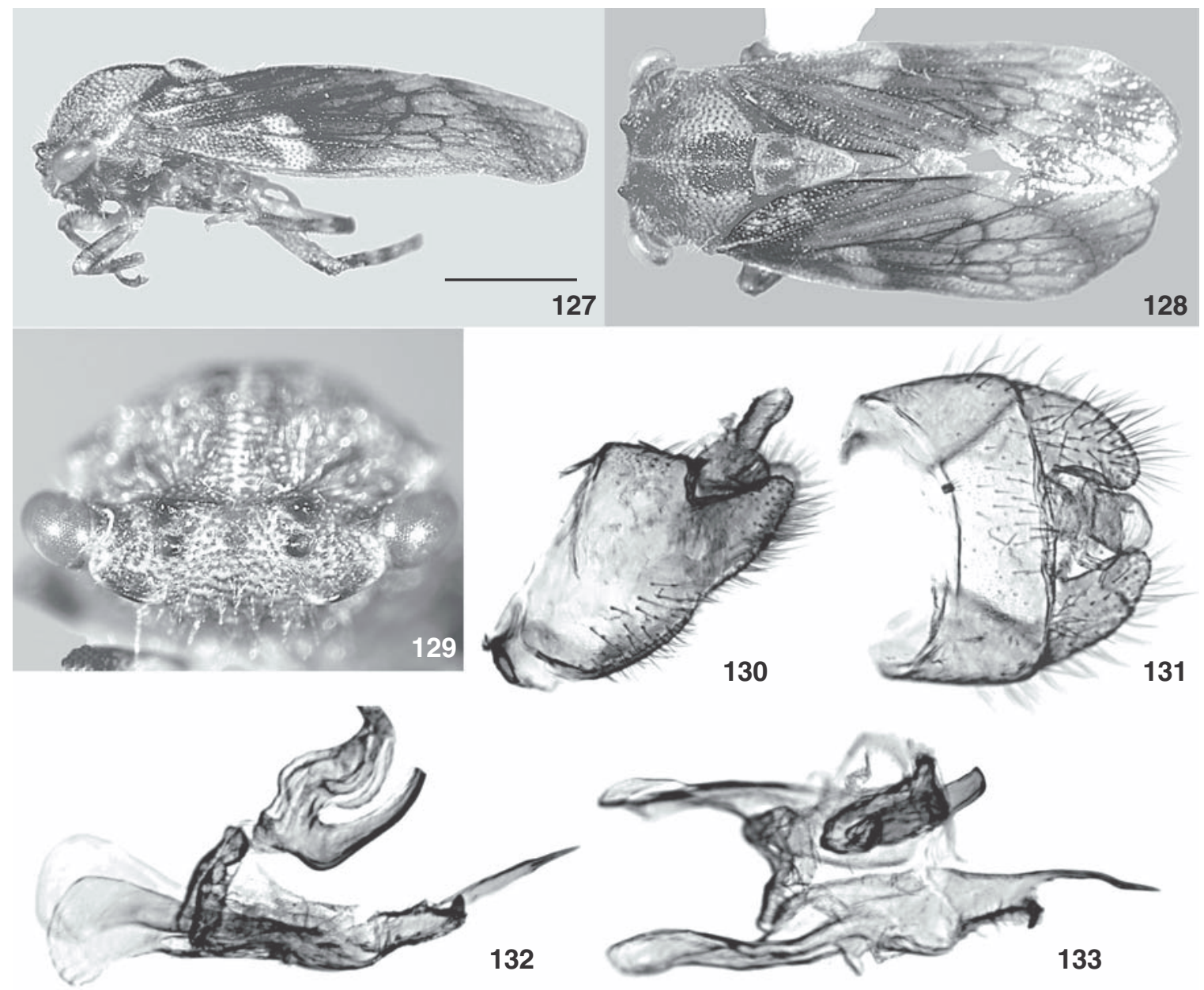

Figures 127-133. Stalomia veruta, gen. nov. (127-129) Habitus, holotype male: (127) left lateral view; (128) dorsal view; (129) anterior view; (130-133) male: (130) pygofer, lateral view; (131) pygofer, dorsal view; (132) genitalia, lateral view; (133) genitalia, dorsal view.

second anal vein weakly or well developed. Metepimeron concealed by forewing at rest. Legs: pro- and meso- thoracic tibiae slender; mesothoracic femur with dorsal preapical cucullate setae; tibia with 0 to 2 cucullate setal rows; metathoracic trochanter without spines; tibia with cucullate setal rows I, II, and III. Furcasternum reduced, without lobes. Abdomen. Terga without conspicuous pits; sternite III without medial keel. Male. Sternite VIII without anterior carina or keeled projection. Pygofer without conspicuous pits or anterior carina dorsally; subgenital plates incompletely fused. Female. Pygofer dorsal posterior margin straight, dorsolateral depressions indistinct or absent. Second valvulae width more or less uniform throughout or abruptly broadened near midlength; uniformly dentate dorsally.

Nymph. Vertex width between eyes more than $2 x$ the height of vertex, produced laterally ventrad of eyes; dorsal processes prominent; dorsal margin with many small chalazae, some species with prominent chalaza dorsad of eye, extending laterally; ventrolateral margin with numerous small and/or large chalazae. Frontoclypeus folded. Pronotum weakly to strongly produced dorsally and compressed; metopidium with numerous tubercles and/or chalazae; submedian tubercles at the dorsal extreme of the pronotal crest absent or present; suprahumeral horn buds or ridges present; not produced posteriorly; ventrolateral margin varying from truncate to angulate, with chalazae; posterior margin with small chalazae. Mesonotum median ridge pronounced. Wing pad notched ventrally. Legs slender, margins with chalazae; prothoracic femur with apical row of spines ventrally and prothoracic tibia with basal row of spines. Abdominal terga with 1-3 pairs of dorsomedial chalazae, posterior pair well developed; lateral margin with numerous small chalazae; segment IX greatly elongated, with numerous chalazae on the dorsomedial surface and lateral margins.

Revista Brasileira de Zoologia 22 (1): 231-283, março 2005 
Distribution. Bolivia, Brazil, Costa Rica, Ecuador, French Guiana, Guatemala, Guyana, Honduras, Mexico, Paraguay, Panama, Peru, Surinam, Venezuela.

Host Plants: Annona muricata (Annonaceae), Luhea seemanni (Tiliaceae). Wood (1984) listed Sapium sp. (Euphorbiaceae) as a host plant of Tolania.

Notes. The diverse male genitalia of Tolania provide excellent characters for distinguishing species. A revision of this genus and descriptions of new species are currently in progress (Albertson and Dietrich, unpublished).

\section{Species transferred to Tolania}

\section{Tolania stria (Cryan \& Deitz, 2002), comb. nov.}

Holdgatiella stria Cryan \& Deitz, 2002: 876.

The holotype was not examined, but Cryan \& Deitz's (2002) illustrations and description of the holotype female indicate that this species is more appropriately placed in Tolania. Specifically, the following characteristics justify the transfer to Tolania: frontoclypeus produced ventrally; forewing vein $\mathrm{R}$ with four branches and one $\mathrm{m}$-cu crossvein present; pronotum with posterolateral projections present; and metathoracic femur ventral cucullate setal row absent. T. stria was originally placed in the genus Holdgatiella based on the lack of suprahumeral horns on the pronotum; however, several Tolania species have been found to share this feature.

\section{Tolania obliqua (Walker, 1858), comb. nov.}

Aethalion [sic] obliquum Walker, 1858: 341. Nicomia obliquum[sic]; Goding, 1927: 187.

Nicomia obliqua is transferred to Tolania based on examination of the holotype (sex unknown) labeled: "Type; Veneza./ 55.89.; AETHALION ? OBLIQUUM.; Albertson Research/ TOL1011" [BMNH]. The abdomen is missing but features of the head (frontoclypeus produced ventrally), scutellum (apex acuminate), mesothoracic tibia (cucullate setal row present), metathoracic leg (trochanter without spines, tibia with three rows of cucullate setae), and forewing venation (presence of only one r-m crossvein) justify transferring this species to Tolania.

\section{Species Removed from Nicomiinae}

\section{Abelus retrospinosus (Lethierry, 1890), comb. nov.}

Nicomia retrospinosa Lethierry, 1890: 155.

This species is transferred to Centrotinae: Abelini based on examination of the holotype male labeled: "Caracas; Nicomia/ retrospinosa/ Leth.; type; Holotype/ Nicomia/ retrospina/ Lethierry/ Michel Boulard det. 1980; Albertson Research/ NIC$0961 \sigma^{\pi \prime \prime}[\mathrm{MNHN}]$. A. retrospinosus was presumably placed in Nicomia based on the absence of a posterior pronotal process. Several aspects of the morphology, including the centrotine forewing venation (vein $\mathrm{R}$ with three branches and vein $\mathrm{M}$ with two branches) and the width of the head less than the width across the pronotal humeri, justify the transfer of this species to Abelus (Centrotinae).

\section{Species of uncertain position}

\section{Tolania armata Goding, 1927}

Tolania armata Goding, 1927: 190. The holotype is apparently lost. Goding (1927: 190) included T. armata in a key to the species of Tolania based on illustrations by Stoll (1788). The illustrations lack detail necessary to determine the species' identity.

\section{Centrotus felinus Germar, 1835}

Centrotus felinus Germar (1835: 259). The holotype is apparently lost. Funkhouser (1927: 494) placed C. felinus in Tolania and considered it a junior synonym of T. obscurus Germar.

\section{Centrotus obscurus Germar, 1835}

Centrotus obscurus Germar (1835: 258). The holotype is apparently lost. One male and four female specimens labeled as C. obscurus types from MLUH were examined. The five specimens represented four different species, none of which matched the original description. FunkHouser (1927: 494) transferred $C$. obscurus to Tolania.

\section{Centrotus fasciatus Walker, 1858}

Centrotus fasciatus Walker (1858: 161). Walker described Centrotus fasciatus in 1851 and in 1858. Goding (1931b: 935) was unable to locate the type of $C$. fasciatus Walker 1851 and, believing C. fasciatus Walker 1858 to be a junior homonym, gave the latter the name Tolania walkeri. The only type found in the British Museum labeled C. fasciatus matches the original 1851 description. It is assumed here that WALKER's (1858) description was either a description of variation within the species or a junior homonym and the type is lost.

\section{Cladistic analysis}

A phylogenetic analysis was performed to examine relationships between Nicomiinae and other membracids, especially with regard to the evolution of wing venation and the posterior pronotal process, to elucidate the status of nicomiine genera, and to estimate relationships among species.

\section{Methods}

\section{Taxa and Characters}

The taxon sample included 62 species of Tolania; ten species of Nicomia; two species of Euwalkeria; and one species in each of Holdgatiella, Nodonica, Eudonica, and Stalomia. Species for which only the female is known were excluded because of the large amounts of missing data. Undescribed species of Tolania are designated by capital letters. Formal descriptions of these species will be published in a subsequent monograph (Albertson \& Dietrich, unpublished). 
Potential outgroup taxa included representatives of other genera in the poorly resolved stegaspidine-nicomiine clade of Dietrich et al. (2001): subfamilies Stegaspidinae (Microcentrini, Microcentrus Stål; Stegaspidini, Flexocentrus Goding; and unplaced to tribe, Antillotolania Ramos and Deiroderes Ramos), Centrotinae (Centrodontini, Multareoides Cook), and Centronodinae (Centronodus Funkhouser) (Tab. II). The sister group to this clade (DieTrich et al. (2001) was represented by Campylocentrus Stål (Centrotinae).

One hundred twenty-five characters of adult morphology were selected and scored from direct examination of specimens, with the exception of genitalia in three of the outgroup taxa scored from illustrations in the literature (male Antillotolania, female Campylocentrus, and female Deiroderes). Characters and character states are listed in Appendix 1. Intermediate states were used for taxa polymorphic for characters of the suprahumeral horns (characters 22, 23, and 24), while all other polymorphisms were coded as the state occurring in most specimens of that species. Forewing crossveins $\mathrm{s}, \mathrm{r}-\mathrm{m}$, and $\mathrm{m}$ often varied between the two forewings of a single specimen in the genus Tolania and were coded as the lesser number of crossveins. Sexually dimorphic characters (character 64 in Euwalkeria) were coded according to the state found in the male of that species.

The data matrix of 85 taxa and 125 characters is shown in Appendix 2. Question marks in the matrix refer to missing data or inapplicable characters.

\section{Analysis}

A heuristic maximum parsimony analysis was conducted using PAUP* 4.0 (SwOFFord 1998) with 20 random taxon addition sequence replicates and tree bisection and reconnection (TBR) branch swapping. The 46 multistate characters were given equal weight and treated as ordered (additive) except for eleven multistate characters treated as unordered (non-additive) (characters 18, 31, 33, 41, 46, 86, 87, 92, 114, 119, and 120).

Approximate decay indices (DI) (BREMER 1994) were calculated by using the "Enforce Topological Constraints" option in PAUP and performing a search for the shortest tree that did not recover each clade consistently recovered in the original analysis. The decay index is the difference between the length of the most parsimonious tree found with the constraint enforced and the length of the original most parsimonious tree(s).

An apomorphy list was generated by PAUP 3.1.1 (SWOFFORD 1993) using the accelerated transformation (ACCTRAN) option, which favors reversals over parallelisms.

\section{Results}

The phylogenetic analysis yielded 1,273 equally parsimonious trees of length 844 (CI 0.23, RI 0.77, and RC 0.15). Eight characters were parsimony uninformative (autapomorphies). The majority-rule consensus tree is illustrated in figure 134; nodes found in all most parsimonious trees are numbered below each branch and the subtending apomorphies for these nodes and for species are listed in table III. The decay indices (figure 134, given in parentheses) show that support was generally low for all nodes with the exceptions of moderate support for Tolania (node 17) and Euwalkeria (node 5) and high support for Nicomia (node 8).

The results support the expansion of the concept of Nicomiinae to include the following genera: Eudonica, Euwalkeria, Holdgatiella, Nicomia, Nodonica, Stalomia, and Tolania. Unresolved clades were limited to relationships among species of Tolania.

\section{Discussion}

Previous morphology-based analyses of Membracidae (Dietrich \& Deitz 1993, Dietrich et al. 2001, Cryan et al. 2003), which included single representatives of nicomiine genera, were unable to assess the phylogenetic status of these taxa or resolve their relationships. Recent molecular phylogenetic analyses of Membracidae included one (Lin et al. 2004) or no (CRYAN et al. 2000, 2004) exemplars of Nicomiinae. The most comprehensive previous morphology-based analysis (Dietrich et al. 2001) grouped Nicomiinae (as here defined) in a clade with Stegaspidinae, Centronodinae, Centrodontini, and the unplaced genus Togotolania. This clade, relationships within which were poorly resolved, was sister to a clade comprising Centrotinae, Membracinae, Heteronotinae, Darninae, and Smiliinae. Only one representative of the latter clade (Centrotinae: Campylocentrus) was included in the present analysis. Rooting the tree as shown in figure 134, or to Campylocentrus alone, renders the included Stegaspidinae paraphyletic, in contrast to the results of CRYAN et al. (2003); but this difference is probably attributable to sampling bias. Thus, the relationship of Nicomiinae to other subfamilies was not resolved by our analysis.

Despite these uncertainties, the present analysis, which included many more characters than previous morphologybased analyses of Membracidae, and nearly all known species of Nicomiinae, provides support for the monophyly of Nicomiinae, as here redefined, as well as for the included genera. Relationships within the largest genus, Tolania, were poorly resolved but several species groups with low to moderate support were revealed.

Table III lists two synapomorphies as unique to Nicomiinae (node 1): forewing vein $\mathrm{R}$ with four or more branches (char. 36, state 1); and vein $\mathrm{M}$ with three or more branches (char. 37, state 1). These features are only unique to Nicomiinae if taxa having reticulate forewing venation are scored as missing values for this character. Reticulate venation occurs in the outgroup Centronodinae and Centrodontini, as well as in the nicomiine genera Nodonica and Euwalkeria. Nine additional synapomorphies listed for node 1 in table III do not occur in all species. Results of recent phylogenetic analyses (CRYAN et al. 2000, 2004, Lin et al. 2004, Wallace \& Deitz 2004) provide strong support for placement of Centrodontini as a tribe of Centrotinae, but the phylogenetic position of Centronodinae has not yet been elucidated satisfactorily.

Revista Brasileira de Zoologia 22 (1): 231-283, março 2005 


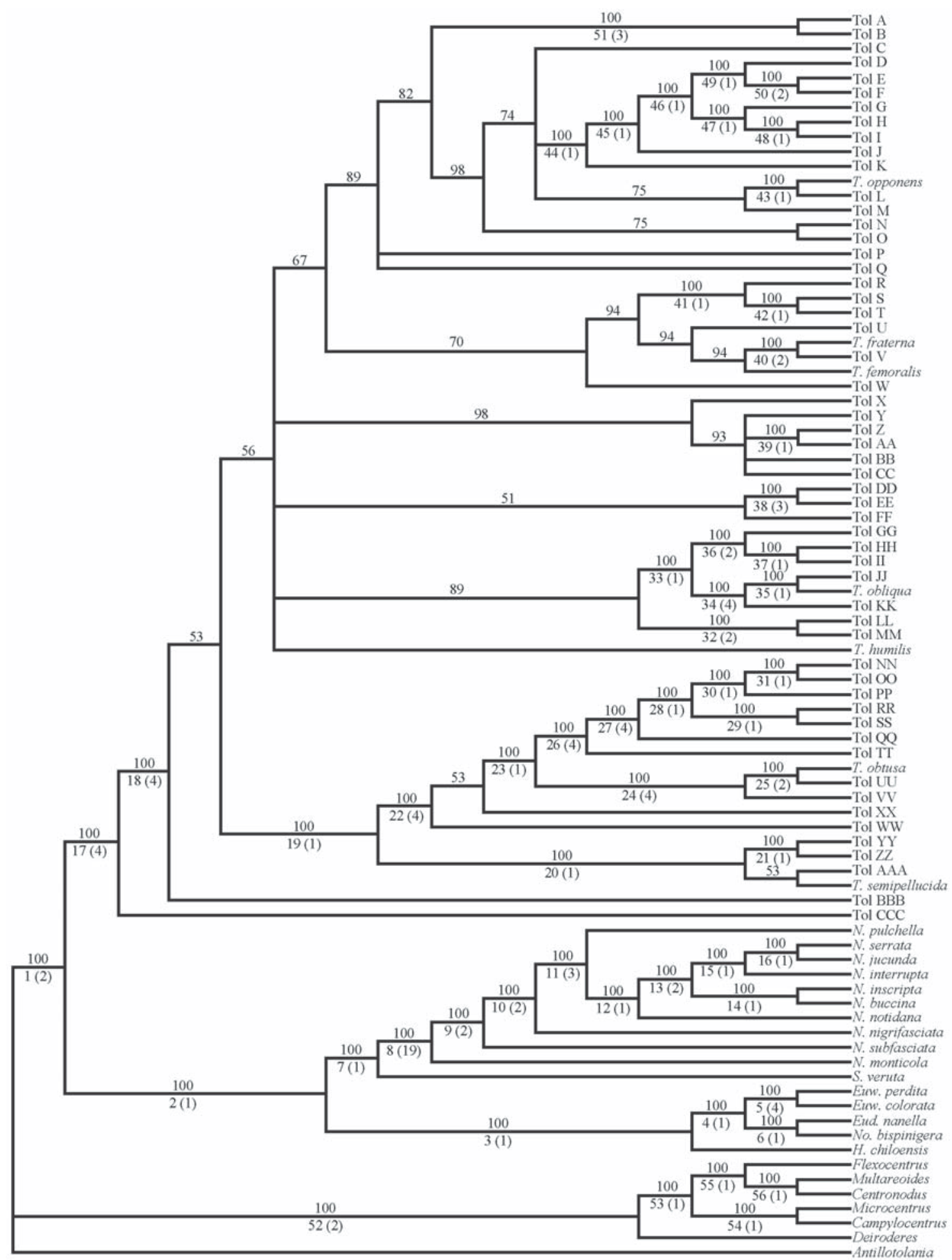

Figure 134. Majority-rule consensus tree of 1,273 equally most parsimonious trees. Numbers above the branches indicate the percentage of trees containing that node; numbers below the branches indicate the node number followed by the decay index in parentheses. Apomorphies for numbered nodes are listed in table III.

Revista Brasileira de Zoologia 22 (1): 231-283, março 2005 
Table II. Specimens examined for outgroups in the phylogenetic analysis. Data are listed as follows: genus: taxa represented: material examined [repositories]. Male characters for Antillotolania Ramos were based on illustrations by CRYAN \& BARTLETT (2002). Female characters for Campylocentrus Stål and Deiroderes Ramos were based on illustrations by Deitz (1975) and CrYAN \& Deitz (2002) respectively.

Antillotolania Ramos: Antillotolania extrema Cryan \& Bartlett [GMNH, holotype female]. Campylocentrus Stål: Campylocentrus sp. [INHS]. Centronodus Funkhouser: Centronodus sp. [INHS]. Deiroderes Ramos: Deiroderes punctata (Metcalf \& Bruner) [AMNH]. Flexocentrus Goding: Flexocentrus sp. [MNHN]. Microcentrus Stål: Microcentrus sp. [BMNH, INHS]. Multareoides Cook: Multareoides sp. [INHS].

Tolania formed a monophyletic group (node 17) and represented a sister clade to the remaining Nicomiinae genera (node 2). The six genera subtended by node $2(\mathrm{DI}=1)$ are united in having sternite VIII more than twice as wide as long (char. 76) and in lacking well developed suprahumeral horns (char. 22).

The genera subtended by node 3 (Holdgatiella, Nodonica, Eudonica, and Euwalkeria) are united in having the pronotum posterior margin without posterolateral projections (char. 30) and the forewing with two or more m-cu crossveins (char. 42). All of the genera in this group, except Eudonica, have a dorsal postocular pronotal keel (char. 19), a character also present in several outgroups but lacking in Tolania, Nicomia, and Stalomia.

Several characters distinguish Holdgatiella from its sister clade (node 4), particularly features of the metathoracic femur cucullate setal rows (chars 61, 62, and 63) and of the male genitalia (chars 110, 119, and 120). Holdgatiella resembles members of the subfamily Stegaspidinae (Microcentrus, Flexocentrus, Antillotolania, and Deiroderes) in having arcuate chaetoids on the hindwing apex (char. 53).

Nodonica, Eudonica, and Euwalkeria (node 4, DI = 1) are supported as a monophyletic group by twelve characters, including the median pronotal carina strongly keeled (char. 18); the presence of suprahumeral tubercles (char. 22); pronotum posterior margin rounded (char. 30); scutellum apex emarginate (char. 32); forewing with supranumerary crossveins (char. 35); and the tibiae foliaceous (char. 56). These three genera also have the distance from the eye to the wing base more than half the eye width (char. 21), but this character is also present in the outgroups.

Nodonica was originally placed in the subfamily Centrodontinae (Dietrich et al. 2001) based on the concealed scutellum, supranumerary forewing veins, and confluent hindwing $\mathrm{R}_{4+5}$ and $\mathrm{M}_{1+2}$ veins. More detailed analyses of morphological characters supported placement of Centrodontini, excluding Nodonica, in Centrotinae (Wallace \& Deitz 2004). The present analysis also indicates that similarities between Nodonica and Centrodontini are the result of convergence, and that Nodonica is more appropriately placed in Nicomiinae.

The genus Euwalkeria (node 5) is monophyletic with moderate support ( $D I=4$ ) and the two species included in the analysis have several synapomorphies including: the frontoclypeus flattened (char. 11); a ventral postocular keel present (char. 20); and the aedeagus shaft broad in lateral view, strongly compressed in ventral view (char. 100). The species of Euwalkeria (except E. rubrica, not included in analysis) also possess dark tubercles on the forewing veins (char. 48), a character also found in the outgroups Deiroderes and Microcentrus.

The genera Nodonica and Eudonica were recovered as sister groups (node 6) with low support (DI = 1) and united by five characters including: frontoclypeus with a transverse fold (char. 12); metopidium high, nearly vertical (char. 15); metathoracic tibia with cucullate setal rows II and III (char. 64); and sternite IX with the anterior margin emarginate (char. 90). Several characters distinguish these two genera, including: shape of lateral plates (char. 87); head width (char. 1); posterior pronotal process (char. 29); anal veins (char. 52); and shape of aedeagus in lateral view (char. 96).

Nicomia was united with Stalomia (node 7) based on the presence of two $\mathrm{r}-\mathrm{m}$ crossveins in the forewing, with $\mathrm{r}-\mathrm{m}_{1}$ basad of $R_{1}$ and perpendicular to veins $\mathrm{R}$ and $\mathrm{M}$ (char. 41, state 3 ). However, support for this clade was low $(\mathrm{DI}=1)$. Stalomia resembles Tolania in having three rows of cucullate setae on the metathoracic tibia (char. 64).

Stalomia veruta was placed in a monotypic genus because of the large number of autapomorphies (11) distinguishing it from Nicomia, including: shape of vertex dorsal processes (char. 4); stalked ocelli (char. 8); presence of a ventral postocular keel (char. 20); forewing with two s crossveins (char. 39) and two $\mathrm{m}-\mathrm{m}$ crossveins (char. 44 ); and male style with an apical process (char. 120).

Nicomia (node 8) was a well supported (DI = 19) monophyletic group with several unique synapomorphies, including the metepimeron exposed by the forewing at rest (char. 68 ), the presence of hind trochanter spines (char. 59), the lobed furcasternum (char. 67), and the genital capsule retracted into abdomen (char. 81). Several other apomorphies unite the species of Nicomia, including: frontoclypeus flattened (char. 11); the pronotum posterior margin angulate with posterolateral projections (char. 30); forewing m-cu crossvein connected distad of second $\mathrm{M}$ fork (char. 43); clavus truncate (char. 50); metathoracic tibia with cucullate setal rows II and III (char. 64); tymbals large and conspicuous (char. 69); and sternite VIII with a posterior keeled projection (char. 79).

The genus Tolania (node 17) forms a monophyletic group with moderate support $(\mathrm{DI}=4)$. The monophyly of Tolania is supported by: frontoclypeus produced ventrally (char. 11, states 2 and 3); absence of a ventral postocular keel (char. 20); pronotum posterior margin angulate with posterolateral projections (char. 30); prothoracic coxae nearly touching (char. 55); and tymbals visible (char. 69, states 1 and 2). The species 
Table III. List of apomorphies for nodes of cladogram in figure 134. Characters are listed with states in parentheses. Non-homoplasious changes are indicated with an asterisk $\left({ }^{*}\right)$.

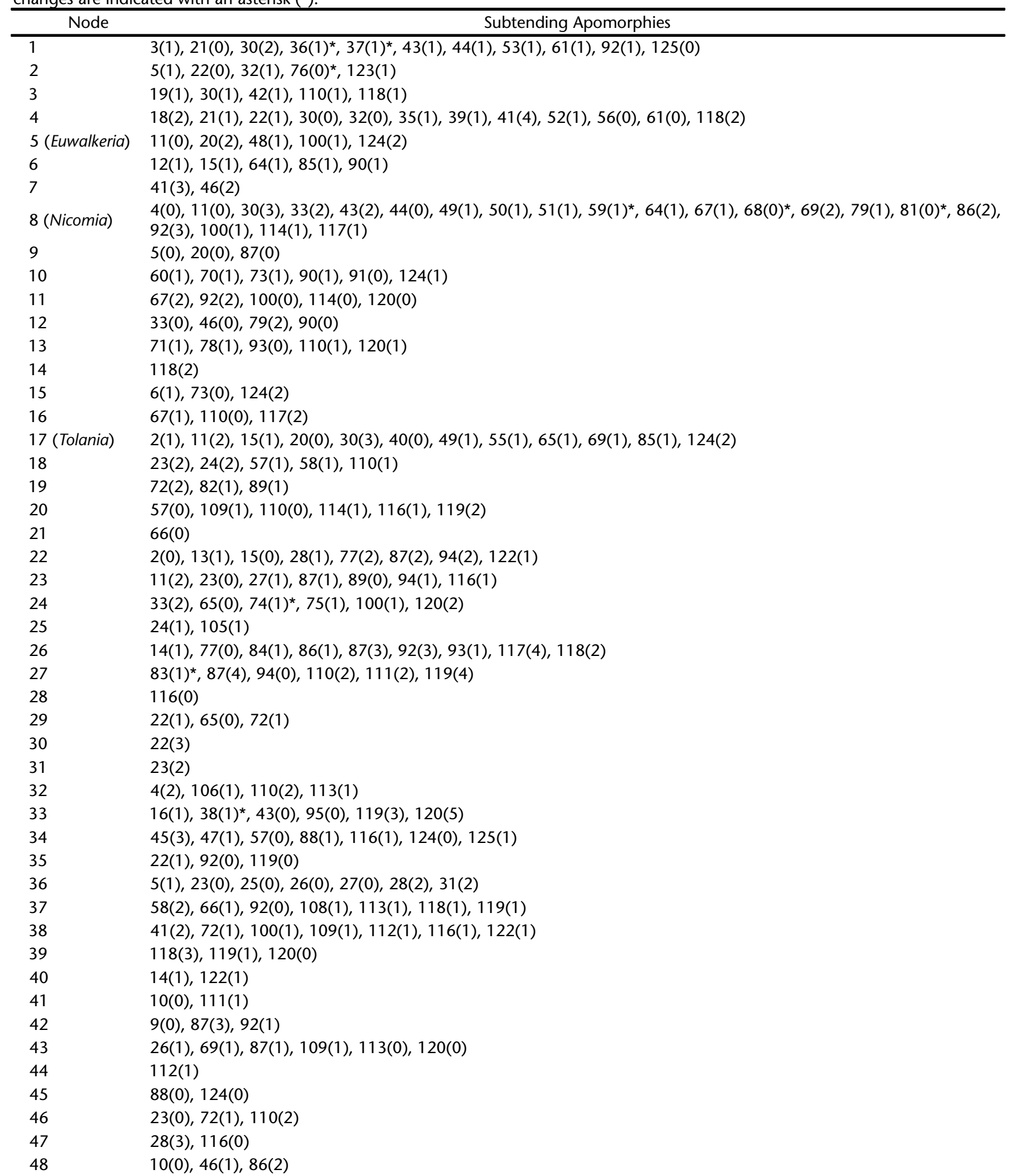


Table III. Continued.

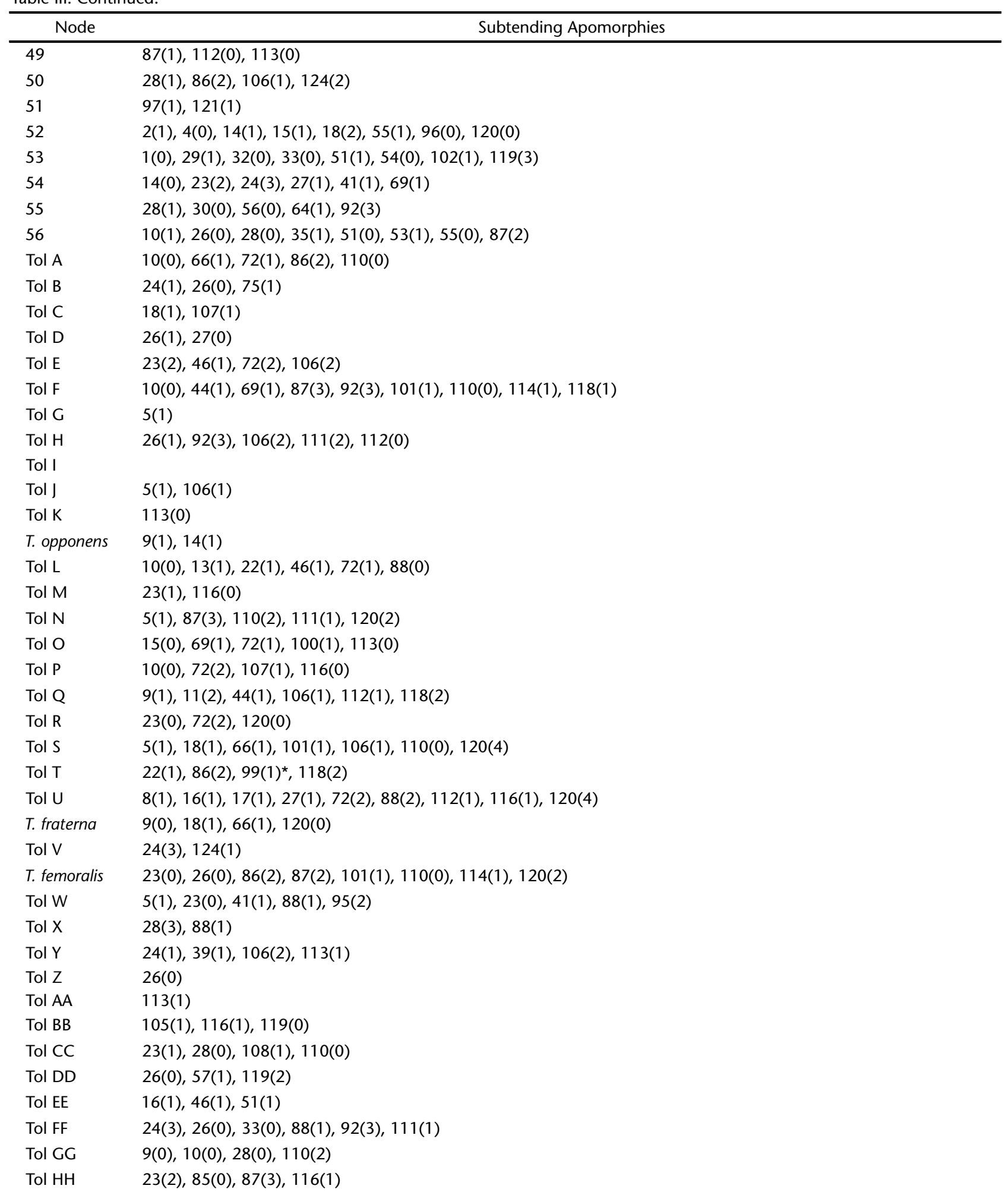


Table III. Continued.

\begin{tabular}{|c|c|}
\hline Node & Subtending Apomorphies \\
\hline Tol II & 18(0), 25(1), 27(1), 31(0), 45(1), 88(1) \\
\hline Tol JJ & $5(1), 57(1), 65(0), 97(2), 113(1), 120(1)$ \\
\hline T. obliqua & $11(2), 12(1), 15(0), 18(0), 22(0), 45(2), 112(1)$ \\
\hline Tol KK & $4(2), 16(0), 85(0), 102(1), 118(1)$ \\
\hline Tol LL & $8(0), 22(2), 23(1), 24(1), 51(0), 72(1), 92(3), 103(1)^{*}$ \\
\hline Tol MM & $10(0), 26(0), 27(0), 57(1), 106(2), 112(1)$ \\
\hline T. humilis & 13(1), 28(0), 58(2), 82(1), 92(3), 100(1), 105(1), 110(0), 114(1), 118(2) \\
\hline Tol NN & $84(2), 116(1)$ \\
\hline \multicolumn{2}{|l|}{ Tol OO } \\
\hline \multicolumn{2}{|l|}{ Tol PP } \\
\hline \multicolumn{2}{|l|}{ Tol QQ } \\
\hline Tol RR & $22(0), 41(1), 84(2), 111(1)$ \\
\hline Tol SS & $36(2)^{*}, 57(0), 72(0), 87(3), 95(1), 105(1), 119(0)$ \\
\hline Tol TT & $22(0), 57(0), 84(2), 120(3)$ \\
\hline T. obtusa & $23(2), 97(2), 110(2)$ \\
\hline Tol UU & $28(2)$ \\
\hline Tol VV & $22(3)$ \\
\hline Tol WW & $24(3), 26(0), 41(1), 75(1), 117(4), 118(2), 121(1)$ \\
\hline Tol XX & $2(1), 13(0), 24(1), 57(2), 66(0), 82(0), 110(0), 114(2), 117(2), 122(0)$ \\
\hline Tol YY & $27(1), 28(3)$ \\
\hline Tol ZZ & $24(3), 26(0), 43(2)$ \\
\hline T. semipellucida & $28(3)$ \\
\hline Tol AAA & $23(1), 26(0), 27(1), 72(1), 77(1), 95(0)$ \\
\hline Tol BBB & $7(1), 10(1), 14(1), 24(3), 58(2), 66(0), 85(0), 108(1), 119(1), 120(5)$ \\
\hline Tol CCC & $12(1), 18(1), 35(1), 82(1), 116(1)$ \\
\hline N. pulchella & $31(1), 57(1), 82(1), 87(3), 104(1)^{*}, 117(2)$ \\
\hline N. serrata & $40(0), 73(1), 80(1), 90(1), 92(4), 114(2), 117(3)$ \\
\hline N. jucunda & $60(2), 79(1), 100(1), 118(2), 120(0)$ \\
\hline N. interrupta & $4(1), 5(1), 33(2), 46(2), 82(1), 89(1), 97(1), 98(1)^{*}$ \\
\hline N. inscripta & $93(1), 100(1), 117(2)$ \\
\hline N. buccina & $60(0), 79(1), 80(1), 92(1), 116(1), 117(0)$ \\
\hline N. notidana & $85(1), 87(1), 91(1), 117(0)$ \\
\hline N. nigrifasciata & $40(0), 60(0), 80(1), 93(0)$ \\
\hline N. subfasciata & $6(1), 78(1), 117(0), 125(1)$ \\
\hline N. monticola & $31(1), 34(1)^{\star}, 71(1), 118(2)$ \\
\hline Stalomia & $4(3), 8(1), 10(1), 20(2), 39(1), 40(0), 44(2), 47(1), 95(1), 119(3), 120(4)$ \\
\hline E. perdita & $5(0)$ \\
\hline E. colorata & $87(1), 89(1)$ \\
\hline Eudonica & $19(0), 87(5), 92(2), 118(0)$ \\
\hline Nodonica & $1(0), 3(0), 5(0), 7(1), 20(0), 29(0), 47(1), 52(0), 55(1), 89(1), 96(0), 119(3), 120(0)$ \\
\hline Holdgatiella & $\begin{array}{l}3(0), 13(1), 20(0), 32(2), 33(0), 53(0), 54(0), 55(1), 61(2), 62(1)^{*}, 63(1)^{*}, 66(0), 92(3), 110(2), 119(1), 120(5), \\
123(0)\end{array}$ \\
\hline Flexocentrus & $7(1), 82(1)$ \\
\hline Multareoides & $8(1), 9(0), 14(0), 16(1), 29(0), 35(2), 66(0), 70(1), 73(1), 102(0), 114(2)$ \\
\hline Centronodus & $12(1), 13(1), 19(1), 20(0), 54(1), 61(1), 85(1), 118(2), 119(0)$ \\
\hline Microcentrus & $2(0), 4(1), 5(1), 7(1), 11(0), 16(1), 30(3), 42(1), 48(1), 61(1), 65(1), 85(1), 87(2), 95(1), 117(0), 124(1), 125(0)$ \\
\hline Campylocentrus & $11(3), 12(1), 15(0), 18(0), 19(1), 20(0), 22(0), 40(0), 43(2), 47(1), 50(1), 53(1), 69(2), 70(1), 82(1), 119(0)$ \\
\hline Deiroderes & $5(1), 19(1), 22(1), 40(0), 45(1), 48(1), 61(1), 85(1), 87(1)$ \\
\hline Antillotolania & $4(3), 9(0), 11(0), 12(1), 41(3), 42(1), 64(0), 91(0)$ \\
\hline
\end{tabular}

Revista Brasileira de Zoologia 22 (1): 231-283, março 2005 
are also united in having three rows of cucullate setae on the metathoracic tibia (char. 64).

Due to the substantial variation in aedeagal morphology among species of Nicomiinae, it is difficult to determine and interpret homologies among structures; this appears to be the major cause of the lack of phylogenetic resolution within Tolania. Nevertheless, despite the large number of trees, there are many stable groupings, as indicated on the majority rule consensus tree (Fig. 134).

Tolania CCC was consistently sister to a clade comprising all other species of Tolania, this species may eventually be determined to represent a distinct genus based on several synapomorphies unique among Tolania, including the frontoclypeus with a transverse fold (char. 12), the forewing with supranumerary crossveins (char. 35), as well as characters of the male genitalia.

The species subtended by node $24(\mathrm{DI}=4)$ are characterized by having the sternite VI width more than twice the width of sternites VII and VIII (char. 74), a unique synapomorphy within Nicomiinae; the aedeagus shaft broad in lateral view and strongly compressed in ventral view (char. 100); and the style apex serrate and notched (char. 120).

Species subtended by node $26(\mathrm{DI}=4)$ are united by features of the frontoclypeus lateral lobes (char. 14); the pygofer with blunt lobes posteriorly (char. 84); and the lateral plates auriculate (char. 87) and extending laterally (char. 86).

The monophyly of clade 27 is supported by the male pygofer with a dorsal median posterior process (char. 83), a unique synapomorphy within Nicomiinae but also present in some species of Centrotinae (Wallace \& Deitz 2004), and the aedeagus with two or more apical processes (char. 110), one process with multiple finger-like projections (char. 111).

The species subtended by node $20(\mathrm{DI}=1)$ resemble each other in attributes of the male genitalia: aedeagus apex broad and massive (char. 109); aedeagus with an apical flange (char. 114); gonopore apical (char. 116); and the style shank strongly concave ventrally (char. 119).

The species subtended by node 33 form a monophyletic group with low support $(\mathrm{DI}=1)$. These species share features of the pronotum (punctation sparse, char. 16) and two unique synapomorphies among Nicomiinae, the forewing vein $\mathrm{M}$ initially divided into $\mathrm{M}_{1+2+3}$ and $\mathrm{M}_{4}$ (char. 38) and the forewing $\mathrm{m}$ $\mathrm{cu}$ crossvein connected basad of the second $\mathrm{M}$ fork (char. 43). Species subtended by node 34 are united in having a forewing macula along vein $\mathrm{Cu}_{1}$ and at the apex of the middle anteapical cell (char. 45); the forewing membrane bicolor (char. 47); features of the male (chars 88 and 116) and female (chars 124 and 125) genitalia. The monophyly of clade 36 is supported by the vertex dorsomedial surface distinctly concave (char. 5); the scutellum base produced dorsally and acute (char. 31); and characters of the suprahumeral horns (chars 23, 25, 26, 27, and 28).

Several species of Tolania (TOL X, Y, Z, AA, BB, and CC) form an easily recognizable group because they have two $\mathrm{r}-\mathrm{m}$ crossveins in the forewing with $\mathrm{r}-\mathrm{m}_{1}$ basad to $\mathrm{R}_{1}$ and slanting (char. 41). These species formed a monophyletic group in $93 \%$ of the most parsimonious trees (Fig. 134).

\section{Concluding remarks}

Morphological evidence supports expansion of the concept of Nicomiinae to include Eudonica, Euwalkeria, Holdgatiella, Nicomia, Nodonica, Stalomia, and Tolania. Cladistic analysis supports the monophyly of Nicomiinae and its constituent genera. Relationships within Nicomia were well resolved by morphological characters, but many relationships among species and groups of Tolania remain poorly resolved due to uncertainties over the homology of features of the highly diverse male genitalia.

A large proportion of nicomiine species are known only from a few specimens in museum collections; thus intensive sampling in the New World tropics will be needed prior to any attempt to resolve relationships using molecular data. Additional morphological characters, especially those of the female genitalia and nymphs, may also help resolve relationships within this genus. However, due to the high degree of similarity in coloration and external morphology among many Tolania species, females are difficult to associate with males for many species and few nymphs have been collected.

Cladistic analysis of Nicomiinae indicates, as was suggested by other recent analyses of Membracidae (Dietrich \& Deitz 1993, Dietrich et al. 2001, Cryan et al. 2003, Cryan et al. 2004, Wallace $\&$ Deirz 2004), that the posterior pronotal process was gained and lost multiple times in the evolution of Membracidae. In the present analysis, absence of a posterior pronotal process (char. 29 , state 2) appears to be plesiomorphic for Nicomiinae, but such a process was gained at least once in Nodonica, and possibly a second time in Euwalkeria latipes, which was excluded from the analysis because only the female of this species is known.

Although the forewing venation is useful for delimiting nicomiine genera and species groups, cladistic analysis did not reveal any obvious trends (either toward greater complexity or simplicity) in the evolution of forewing venation. Based on the present analysis, as well as some previous studies (DieTrich \& Deitz 1993, Dietrich et al. 2001), supranumerary forewing branches and crossveins appear to have been acquired independently multiple times within Membracidae. In Nicomiinae, one relatively derived lineage (Fig. 134, node 4) was characterized by having supranumerary crossveins and this feature was also found in one species of Tolania (Tol CCC).

The aedeagus is highly variable among Nicomiinae species, an unusual phenomenon in membracids where the aedeagus is often highly conserved within genera. Even more remarkably, Nicomia females vary interspecifically in both the shape of the pygofer dorsum and the shape of the dorsal teeth on the second valvulae. Observations of the ecology of these species are needed to determine if these variations are correlated with differences in oviposition sites. 
Another point requiring further study is the remarkable degree of color polymorphism within some nicomiine species. Possibly these polymorphisms reflect differences in age or host association among individuals, but it is possible that some of these color variants represent distinct species. Further collecting and ecological observations are needed to resolve this issue.

Based on the available specimens, there are no obvious biogeographical patterns that might explain how the various genera of Nicomiinae diversified (Fig. 135). Nicomiinae specimens are rarely collected and females are often difficult to associate with males. Therefore, their true distribution is not known. Further collecting is needed to provide a more accurate estimate of the geographical range of nicomiine species.

This study revealed that Nicomiinae is much more speciose than was previously suspected. Sixteen of the 22 species treated here are new, and 66 species (55 new) of Tolania will be treated in a subsequent monograph. Thus, the known fauna has increased from 19 to 88 species. Given that vast areas of the Neotropical region remain poorly sampled, many additional nicomiine species undoubtedly await discovery. Observations on the ecology and life history of these species, viewed within the context of the phylogenetic estimate presented here, may help elucidate the factors that yielded the high degree of diversity in this group.

\section{ACKNOWLEDGEMENTS}

We are indebted to C. B. Barr (Essig Museum of Entomology), M. Boulard (Museum National d'Histoire Naturelle), E. Cancello (Museu de Zoologia), L. L. Deitz (North Carolina State University), M. Dorn (Martin-Luther-Universität), P.H. Freytag (University of Kentucky), K. G. A. Hamilton (Canadian National Collection of Insects), S. H. McKamey and D. G. Furth (National Museum of Natural History), F. W. Mead (Florida State Collection of Arthropods), N. D. Penny (California Academy of Sciences), A. M. Sakakibara (Universidade Federal do Paraná), R. T. Schuh (American Museum of Natural History), C. Smith (Georgia Museum of Natural History), H. Strümpel (Zoölogisches Institut und Zoölogisches), B. Viklund (Naturhistorisches Riksmuseet), M. D. Webb (Natural History Museum, London), T. K. Wood, C. W. Young (Carnegie Museum of Natural History), and M. Zumbado (Instituto Nacional de Biodiversidad) for the loan of specimens in their care; and to L.L. Deitz, S.H. McKamey, J. R. Cryan, and R. Rakitov for their insights and suggestions. The manuscript was critically reviewed by J. R. Cryan, L. L. Deitz, A. M. Sakakibara, whose helpful suggestions are gratefully acknowledged. We are also grateful to D. M. Takiya for translating the abstract into Portuguese. The research was supported by a National Science Foundation Partnerships for Enhancing Expertise in Taxonomy (PEET) Grant DEB-9978026.

\section{REFERENCES}

Bremer, K. 1994. Branch support and tree stability. Cladistics, Westport, 10: 295-304.

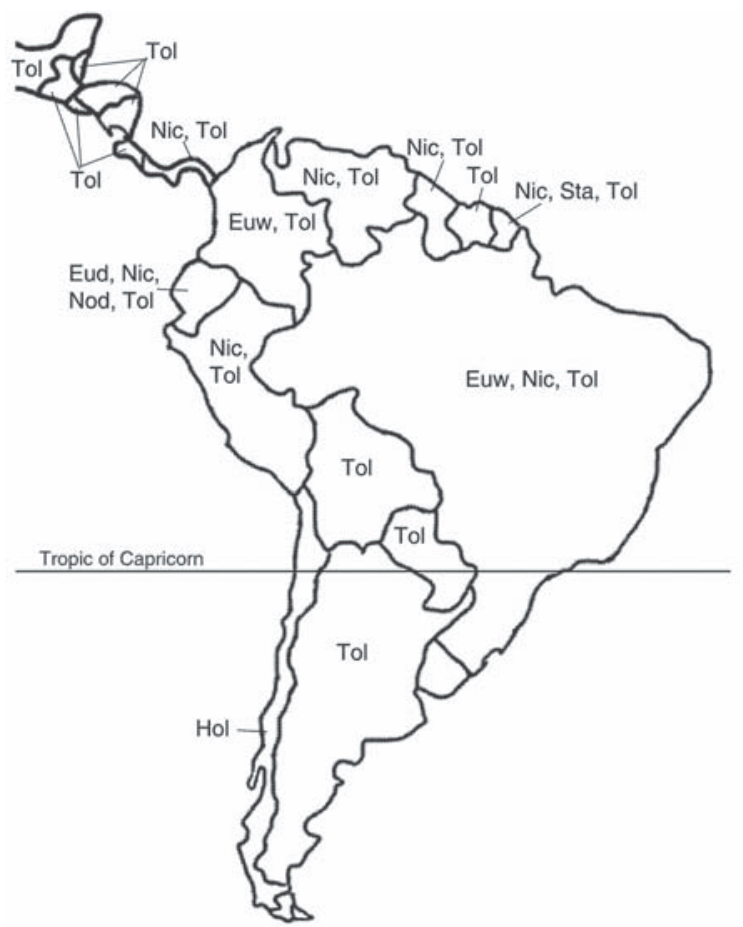

Figure 135. Known country-level distributions of the Nicomiinae genera. (Eud) Eudonica, (Euw) Euwalkeria, (Hol) Holdgatiella, (Nic) Nicomia, (Nod) Nodonica, (Sta) Stalomia, (Tol) Tolania.

CRYAN, J.R. \& C.R. BARTLETT. 2002. A redescription of the Caribbean treehopper genus Antillotolania Ramos (Hemiptera: Membracidae), with two new species. Annals of the Entomological Society of America, Lanham, 95: 302-308.

Cryan, J.R. \& L.L. Deitz. 2002. Enigmatic treehopper genera (Hemiptera: Membracidae): Deiroderes Ramos, Holdgatiella Evans, and Togotolania, new genus. Proceedings of the Entomological Society of Washington, Washington, 104: 868-883.

Cryan, J.R.; B.M. Wiegmann; L.L. Deitz \& C.H. Dietrich. 2000. Phylogenetic relationships of the treehoppers (Insecta: Hemiptera: Membracidae): Evidence from two nuclear genes. Molecular Phylogenetics and Evolution, Orlando, 17: 317-334.

Cryan, J.R.; B.M. Wiegmann; L.L. Deitz; C.H. Dietrich \& M.F. Whiting. 2004. Treehopper trees: phylogeny of Membracidae (Hemiptera: Cicadomorpha: Membracoidea) based on molecules and morphology. Systematic Entomology, London, 29: 441-454.

Cryan, J.R.; J.A. Robertson \& L.L. Deitz. 2003. The New World treehopper tribe Microcentrini (Hemiptera: Membracidae: Stegaspidinae): monographic revision and phylogenetic position. Lanham, Entomological Society of America, III+108p.

Deitz, L.L. 1975. Classification of the higher categories of the 
New World treehoppers (Homoptera: Membracidae). North Carolina Agricultural Experiment Station Technical Bulletin, Raleigh, 225: 1-177.

Deitz, L.L. \& C.H. Dietrich. 1993. Superfamily Membracoidea (Homoptera: Auchenorrhyncha). I. Introduction and revised classification with new family-group taxa. Systematic Entomology, London, 18: 287-296.

Dietrich, C.H. \& L.L. Deitz. 1991. Revision of the Neotropical treehopper tribe Aconophorini (Homoptera: Membracidae). North Carolina Agricultural Research Service Technical Bulletin, Raleigh, 293: 1-134.

Dietrich, C.H. \& L.L. Deitz. 1993. Superfamily Membracoidea (Homoptera: Auchenorrhyncha). II. Cladistic analysis and conclusions. Systematic Entomology, London, 18: 297-311.

Dietrich, C.H.; S.H. McKamey \& L.L. Deitz. 2001. Morphologybased phylogeny of the treehopper family Membracidae (Hemiptera: Cicadomorpha: Membracoidea). Systematic Entomology, London, 26: 213-239.

Evans, J.W. 1946. A natural classification of leaf-hoppers (Homoptera, Jassoidea). Part 2. Aetalionidae, Hylicidae, Eurymelidae. Transactions of the Royal Entomological Society of London, London, 97: 39-54.

Evans, J.W. 1948. Some observations on the classification of the Membracidae and on the ancestry, phylogeny and distribution of the Jassoidea. Transactions of the Royal Entomological Society of London, London, 99: 497-515.

Evans, J.W. 1962. Leafhoppers from Chile collected by the Royal Society expedition to southern Chile, 1958/59 (Homoptera, Cicadelloidea). Annals and Magazine of Natural History, London, (13) 4: 513-517.

Funkhouser, W.D. 1927. Membracidae. General Catalogue of the Hemiptera, Northampton, 1: 1-581.

Funkhouser, W.D. 1943. Membracidae of Guatemala. Annals of the Entomological Society of America, College Park, 36: 455-482.

FunkHouser, W.D. 1951. Homoptera Fam. Membracidae. Genera Insectorum, Bruxelles, 208: 1-383.

Germar, E.F. 1835. Species Membracidum Musae. E.F. Germari. Silbermann Revue Entomologique, Strasbourg, 3: 223-262.

Goding, F.W. 1892. A synopsis of the subfamilies and genera of the Membracidae of North America. Transactions of the American Entomological Society, Philadelphia, 19: 253260.

Goding, F.W. 1926a. New genera and species of Membracidae. Transactions of the American Entomological Society, Philadelphia, 52: 103-110.

Goding, F.W. 1926b. Classification of the Membracidae of America. Journal of the New York Entomological Society, New York, 34: 295-317.

Goding, F.W. 1927. Revision of the Membracidae of South America and Antilles. Journal of the New York Entomological Society, New York, 35: 183-191.

Goding, F.W. 1928. The Membracidae of South America and the Antilles, II. Subfamily Centrotinae. Journal of the New York Entomological Society, New York, 35: 391-408.

Goding, F.W. 1930. Membracidae in the American Museum of Natural History. American Museum Novitates, New York, 421: 1-27.

Goding, F.W. 1931a. Classification of the Old World Membracidae. Journal of the New York Entomological Society, New York, 39: 299-313.

Goding, F.W. 1931b. Synonymical notes on Membracidae. II. Annals of the Entomological Society of America, College Park, 24: 935-936.

Goding, F.W. 1934. The Old World Membracidae. Journal of the New York Entomological Society, New York, 42: 451480.

Hamilton, K.G.A. 1971. Placement of the genus Microcentrus in the Aetalionidae (Homoptera: Cicadelloidea), with a redefinition of the family. Journal of the Georgia Entomological Society, Tifton, 6: 229-236.

Haupt, H. 1929. Neueinteilung der Homoptera - Cicadina nach phylogenetisch zu wertenden Merkmalen. Zoologische Jahrbucher Abteilung fur Systematik, Ökologie und Biologie der Tiere, Jena, 58: 173-286.

Lethierry, L.F. 1890. Voyage de M.E. Simon au Venezuela (Decembre 1887 - Avril 1888) 9e memoire Hemipteres Homopteres. Annales de la Société Entomologique de France, Paris, 10: 147-160.

Lin, C.-P., B. N. Danforth, \& T. K. Wood. 2004. Molecular phylogenetics and evolution of maternal care in membracine treehoppers. Systematic Biology, Lawrence, 53: 400-421.

Linnavouri, R.E. \& D.M. Delong. 1978. The treehoppers (Homoptera: Membracidae) known to occur in Chile. Brenesia, San José, 14-15: 171-194.

McKamey, S.H. 1998. Taxonomic catalogue of the Membracoidea (exclusive of leafhoppers); second supplement to Fascicle 1-Membracidae of the General Catalogue of the Hemiptera. Memoirs of the American Entomological Institute, Gainesville, 60: 1-377.

McKamey, S.H. \& L.L. Deitz. 1991. Revision of the Neotropical treehopper genus Metcalfiella (Homoptera: Membracidae). North Carolina Agricultural Research Service Technical Bulletin, Raleigh, 294: 1-89.

Metcalf, Z.P. \& V. Wade. 1965. General Catalogue of the Homoptera. A Supplement to Fascicle I - Membracidae of the General Catalogue of the Hemiptera. Membracoidea. Raleigh, North Carolina State University, IV+1552p.

STÅL, C. 1858. Nagra nya genera och arter bland Hemiptera. Öfvsigt af Kongliga Vetenskaps-Akademiens Förhandlingar, Stockholm, 15: 248-450.

Stoll, C. 1788. Cigales. Amsterdam, 1788: 1-124.

Swofford, D.L. 1993. PAUP: Phylogenetic Analysis Using Parsimony, Version 3.1.1. Computer program and documentation, Champaign, Illinois Natural History Survey.

Swofford, D.L. 1998. PAUP*: Phylogenetic Analysis Using Par- 
simony (*and other methods), Version 4.0. Sunderland, Sinauer.

WALKER, F. 1851. List of the Specimens of Homopterous Insects in the Collection of the British Museum. London, British Museum, p. 261-636.

WALKER, F. 1858. Supplement. List of the Specimens of Homopterous Insects in the Collection of the British Museum. London, British Museum, 307p.

WALKER, F. 1862. Characters of undescribed species of Homop- tera in the collection of F.P. Pascoe, F.L.S. Journal of Entomology, London, 1: 309-319.

Wallace, M.S. \& L.L. Deitz. 2004. Phylogeny and systematics of the treehopper subfamily Centrotinae (Hemiptera: Membracidae). Memoirs on Entomology, International, Gainesville, 19: IV+1-377.

WooD, T.K. 1984. Life history patterns of tropical membracids (Homoptera: Membracidae). Sociobiology, Chico, 8: 299344.

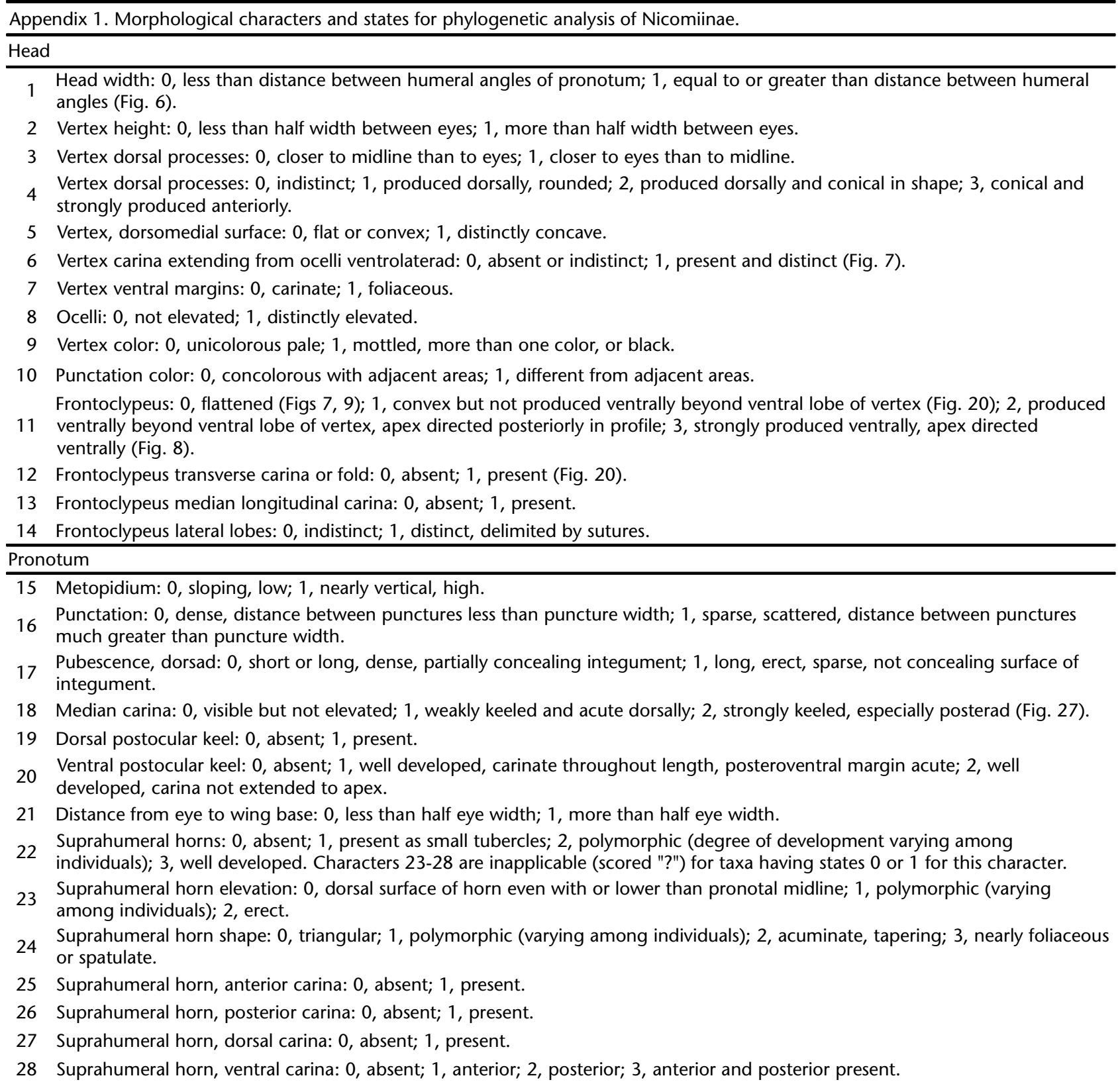

Continued

Revista Brasileira de Zoologia 22 (1): 231-283, março 2005 
Appendix 1. Continued.

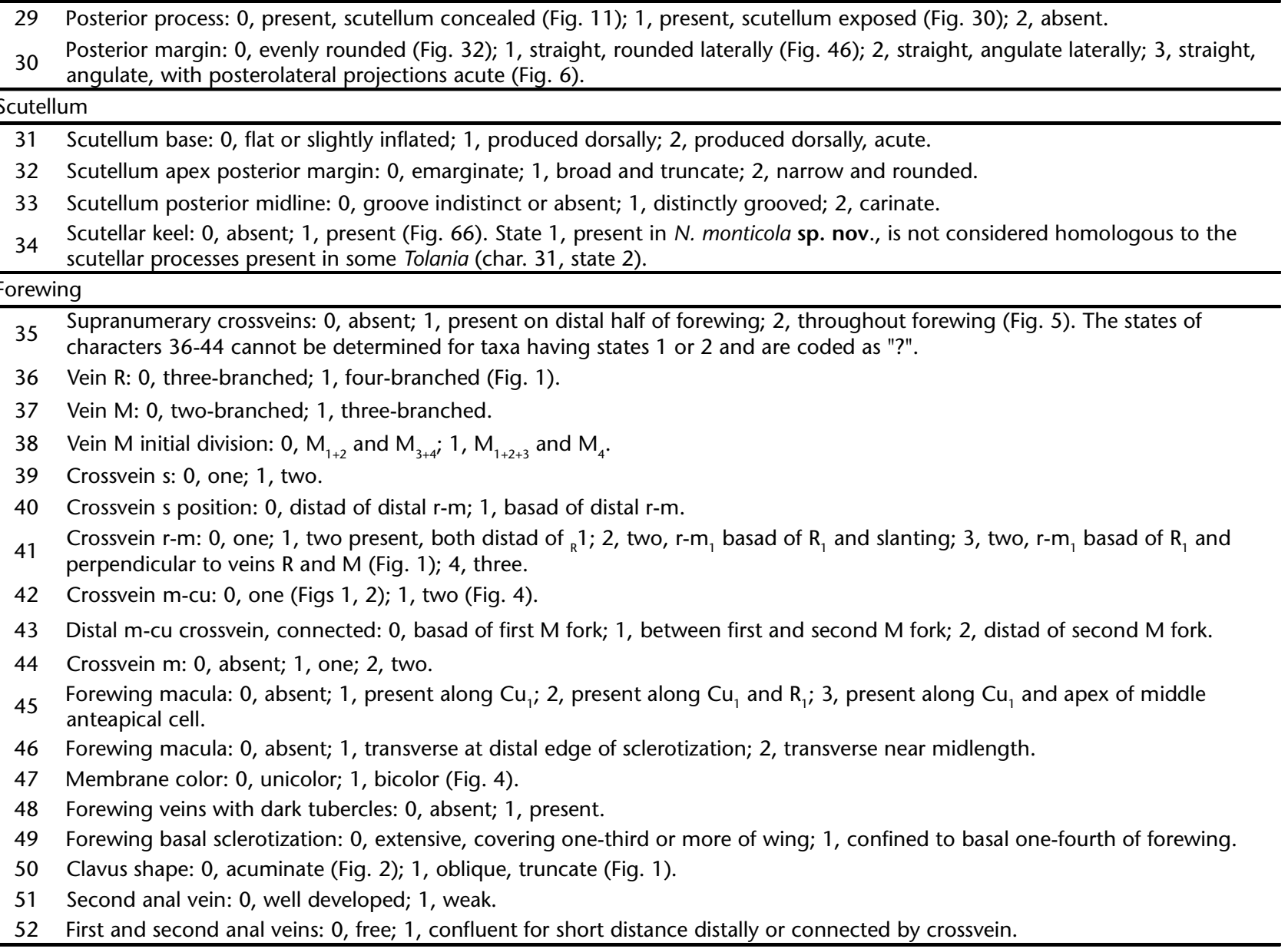
Hindwing

53 Hindwing apical membrane vestiture: 0 , arcuate chaetoids (Fig. 4A); 1, microtrichia.

54 Crossvein m-cu: 0 , more or less parallel to $\mathrm{M}_{3+4}$ before angle, apex of cell acute; 1 , distinctly basad of $\mathrm{M}_{3+4^{\prime}}$ apex of cell truncate.

55 Prothoracic coxae: 0 , widely separated; 1 , nearly touching.

56 Prothoracic and mesothoracic tibia shape: 0 , foliaceous (Fig. 13); 1, slender, bicarinate.

57 Mesothoracic femur, cucullate setae: 0 , absent or only distal pair present; 1 , one or two medial preapical cucullate setae present; 2, numerous preapical cucullate setae present.

58 Mesothoracic tibia, cucullate setae: 0 , absent; 1, row I complete or weakly developed; 2 , row I complete and row II complete or weakly developed.

59 Metathoracic trochanter spines: 0, absent; 1, present (Fig. 12).

60 Metathoracic trochanter spine number: 0 , two; 1 , three; 2, four. If metathoracic trochanter spines are absent (character 58 , state 0 ), then this character is coded as "?".

Metathoracic femur, dorsal cucullate setae: 0 , distal pair of cucullate setae only; 1 , preapical cucullate setae present; 2 , double

61 longitudinal cucullate setal row.

62 Metathoracic femur, anterolateral cucullate setae: 0 , absent; 1 , present.

63 Metathoracic femur, ventral cucullate setal row: 0 , absent; 1 , present.

64 Metathoracic tibia, cucullate setae: 0 , absent or one row present; 1, rows II and III present, complete or partial rows; 2, rows I, II, and III present. 
Appendix 1. Continued.

65 Metathoracic tibia, supranumerary cucullate setae: 0, absent; 1, present between rows II and III.

66 Metathoracic tibiae: 0 , unicolorous, pale; 1 , with maculae.

Thorax

67 Furcasternum: 0, reduced, without lobes; 1, with anterior lobe; 2, with anterior and posterior lobes (Fig. 78).

68 Metepimeron: 0 , exposed by forewing at rest; 1 , concealed by forewing at rest.

69 Tymbals, dorsal, extending past posterior margin of metathorax: 0, absent; 1, present, small; 2, present, large and conspicuous.

Abdomen

70 Tergum with conspicuous pits: 0, absent; 1, present (Fig. 15).

71 Sternite III with medial keel: 0, absent; 1, present.

72 Apodemes on segments IV, V, and VI: 0, absent; 1, present, small; 2, well developed, elongate.

73 Pygofer with conspicuous dorsal pits: 0 , absent; 1 , present.

Male

74 Sternite VI width: 0, slightly wider than sternites VII and VIII; 1, more than twice the width of sternites VII and VIII.

75 Sternite VII: 0 , length less than or equal to width; 1 , length distinctly greater than width.

76 Sternite VIII: 0, width more than twice length; 1, width equal to or less than length.

77 Sternite VIII anterior margin distinctly narrow and rounded: 0, absent; 1, present; 2, present, sternite VII with lateral

77 longitudinal carina and medial depression.

78 Sternite VIII with anterior carina: 0 , absent; 1, present.

79 Sternite VIII with posterior keeled projection: 0, absent; 1 , weakly developed; 2 , well developed.

80 Pygofer dorsal anterior carina: 0, absent (Fig. 80); 1, present (Fig. 79).

81 Genital capsule: 0 , retracted into abdominal segment VIII; 1 , not retracted.

82 Pygofer with distinct anterodorsal microsculpture: 0 , absent; 1, present.

83 Pygofer, dorsal median posterior process: 0 , absent; 1 , weakly or strongly developed.

84 Pygofer, pair of blunt lobes posteriorly: 0 , absent; 1 , length variable, lightly sclerotized; 2 , long and densely sclerotized.

85 Lateral plate length: 0 , less than half length of subgenital plates; 1 , more than half length of subgenital plates.

86 Lateral plate orientation: 0 , extended posteriorly; 1 , extended laterally with median margins divergent; 2 , extended posteriorly with apices strongly curved inward (Fig. 80).

Lateral plate shape: 0, digitiform (Fig. 81); 1 , slender, more or less evenly tapered, apex rounded; 2 , slender, more or less

87 evenly tapered, apex truncate; 3 , robust; 4 , auriculate, with median lateral depression, distal lobe recurved; 5 , broad in dorsal view, sinuate in lateral view (Figs 21, 22).

88 Lateral plate apex digitiform process: 0 , absent; 1 , lightly sclerotized or distally membranous; 2 , densely sclerotized and dorsally produced, barb-like.

89 Lateral plate, ventral process: 0, absent; 1, present (Figs 35, 84).

90 Sternite IX anterior margin: 0 , straight or convex; 1, emarginate medially.

91 Subgenital plate lobes fusion: 0 , complete; 1 , less than complete.

Subgenital plate constriction: 0 , absent, apical two-thirds with lateral margins parallel; 1 , absent, apical two-thirds tapering; 2 ,

92 sub-basal, apical two-thirds with lateral margins parallel; 3, sub-basal, apical two-thirds tapering; 4, sub-basal, apex broad and rounded.

93 Subgenital plate sclerotization: 0 , with densely sclerotized lateral ridge (with setae) and medial basal fenestra (glabrous); 1 , uniformly sclerotized without distinct fenestra.

94 Subgenital plate fold: 0 , absent; 1, abruptly folded dorsally in apical one-third; 2, present with distinct ventral preapical processes.

95 Subgenital plate lateral setae: 0 , simple; 1 , stout, short; 2 , elongate.

96 Aedeagus shaft, lateral view: 0, U-shaped, apex oriented dorsad (Fig. 17); 1, L-shaped, apex oriented posterad.

97 Aedeagus shaft: 0 , straight from basal curve to apex; 1 , enlarged basally and abruptly narrowing distally; 2 , sinuate.

98 Aedeagus with large style-like processes arising from base: 0, absent; 1, present (Fig. 86).

99 Aedeagus, basal dorsal bifurcate process: 0 , absent; 1, present.

100 Aedeagus shaft: 0 , tubular; 1, broad in lateral view, strongly compressed in ventral view (Fig. 39).

Continued.

Revista Brasileira de Zoologia 22 (1): 231-283, março 2005 
Appendix 1. Continued.

101 Aedeagus sub-basal hump: 0, absent; 1, present (Fig. 91).

102 Aedeagus preapical dorsal denticuli: 0, absent; 1, present.

103 Aedeagus preapical ventral distinct microsculpture: 0, absent; 1, present.

104 Aedeagus setae: 0, absent; 1, present (Figs 103, 104).

105 Aedeagus dorsal processes with bases contiguous and lengthwise along shaft: 0 , absent; 1 , present. Aedeagus dorsal processes with bases transverse along shaft: 0 , absent; 1 , one pair, bases contiguous; 2 , one pair, separated at base.

107 Aedeagus ventral processes: 0 , absent; 1 , present, one triangular process or a pair.

108 Aedeagus preapical processes: 0, absent; 1, present.

109 Aedeagus apex: 0, narrow or only slightly enlarged compared to shaft; 1 , broad and massive.

110 Aedeagus apical processes: 0 , absent; 1 , a single process or pair; 2, two or more pairs.

111 Aedeagus apical processes: 0 , simple; 1 , with two to three lobes; 2 , at least one process with multiple finger-like projections. If aedeagus apical processes are absent (character 109, state 0 ), then this character is coded as "?".

112 Aedeagus apical processes: 0 , straight; 1 , curved. If aedeagus apical processes are absent (character 109, state 0 ), then this character is coded as "?".

113 Aedeagus processes: 0 , not movably articulated; 1 , at least one pair movably articulated. If aedeagus apical processes are absent (character 109, state 0 ), then this character is coded as "?".

114 Aedeagus flange: 0 , absent; 1 , surrounding apex and extending at least partially along distal shaft (Fig. 109); 2, extending lengthwise along shaft only (Fig. 106).

115 Aedeagus flange: 0 , entire; 1 , serrate, at least partially. If an aedeagus flange is absent (character 112 , state 0 ), then this character is coded as "?".

116 Gonopore location: 0 , on ventral preapical surface; 1 , apical.

117 Connective, anterior margin: 0 , convex or straight; 1 , weakly emarginate and broadly rounded; 2 , weakly emarginate, apices acuminate; 3, strongly emarginate, apices diverging; 4, strongly emarginate, horseshoe-shaped.

118 Connective, posterior apex: 0 , truncate or broadly rounded; 1 , acuminate; 2 , produced into short arm; 3, produced into long arm.

119 Style shank, lateral view: 0 , straight; 1 , strongly curved dorsally near connective and gradually descending toward apex; 2 , strongly concave ventrally; 3 , gradually curving dorsally toward apex; 4 , sharp bend posterior to connective, straight.

120 Style apex: 0 , slender throughout with apex acute; 1 , apex abruptly bent and blade-like; 2 , serrate and notched; 3 , broad and round, compressed; 4, more-or-less acute with process; 5 , compressed, acutely produced dorsally and laterally curved.

121 Style apex: 0 , directed anteriorly; 1 , recurved.

122 Style apical scales: 0 , absent; 1 , present.

Female

123 Pygofer posterior margin: 0, straight (Fig. 43); 1, emarginate around anal tube (Fig. 111).

124 Second valvulae width: 0, more or less uniform throughout (Fig. 44); 1, with dorsal margin more or less evenly arcuate (Fig. 122); 2, broadened near midlength and dorsal margin distinctly angulate (Fig. 118).

125 Second valvulae, dorsal margin: 0, uniformly dentate (Fig. 114); 1, irregularly dentate (Fig. 126). 
Appendix 2. Data matrix of 124 characters for 77 Nicomiinae species and seven outgroup taxa.

\begin{tabular}{|c|c|c|c|c|c|c|c|}
\hline & 1 & 1111111112 & 2222222223 & 3333333334 & 44444444455 & 555555556 & 66666 \\
\hline & 1234567890 & 1234567890 & 1234567890 & 1234567890 & 12345678901 & 234567890 & 12345 \\
\hline Eudonica nanella & 1011100010 & 1100100201 & $11 ? ? ? ? ? ? 20$ & $00101 ?$ & ????0000000 & $11100000 ?$ & 00010 \\
\hline Euwalkeria perdita & 011000010 & 000000212 & 11 ?? ?? ? ? 20 & 00101 ????? & ????0001000 & $11100000 ?$ & \\
\hline Euwalkeria colorata & 1011100010 & 0000000212 & 11 ? ? ? ? ? ? 20 & 00101 1? ? ? ? & ??? ?0001000 & $11100000 ?$ & 0020 \\
\hline Holdgatiella chiloensis & 1001100010 & 1010000010 & 00 ?? ?? ? ? 21 & 0200011001 & 01110000000 & $00011000 ?$ & 1120 \\
\hline Nicomia inscripta & 1010000010 & 0000000000 & 00 ?? ?? ? ? 23 & 0100011001 & 30200000111 & 011010011 & 10010 \\
\hline N. buccina & 10000010 & 0000000000 & 00 ? ? ? ? ? ? 23 & 0100011001 & 30200000111 & 011010010 & 10010 \\
\hline N. interrupta & 1011110010 & 0000000000 & 00 ?? ?? ? ? 23 & 0120011001 & 30200200111 & 011010011 & 10010 \\
\hline N. jucunda & 0010 & 0000000000 & 00 ?? ?? ? ? 23 & 0100011001 & 30200000111 & 011010012 & 10010 \\
\hline N. monticola & 1010100010 & 0000000001 & 00 ??????23 & 1121011001 & 30200200111 & 011010012 & 10010 \\
\hline N. nigrifasciata & 00010 & 000000 & 00 ? ? ? ? ? ? 23 & 1000 & 30200200111 & 011010 & 010 \\
\hline N. notidana & 10000010 & 0000000000 & 00 ?? ?? ? ? 23 & 0100011001 & 30200000111 & 011010011 & 10010 \\
\hline N. pulchella & 0010 & 0000000000 & 00 ? ? ? ? ? ? 23 & 1001 & 30200200111 & 011011011 & 010 \\
\hline N. serrata & 10010010 & 0000000000 & 00 ?? ?? ? ? 23 & 0100011000 & 30200000111 & 011010011 & 10010 \\
\hline fasciata & & 000 & $00 ? ?$ & 001 & 30200 & 0110 & 010 \\
\hline Nodonica bispinigera & 00010 & 1100100210 & $11 ? ? ? ? ? ? 00$ & ?? ? 1? & $41 ? ? 0010000$ & 011100 & 00010 \\
\hline & & 100 & $00 ? ?$ & 010 & 30120 & 011010 & 020 \\
\hline Tolania femo & 011 & 3000100000 & 0300100023 & 1000 & 001000 & 011110 & 10021 \\
\hline T. fraterna & 01 & 3001 & 0320110023 & 000 & 00100 & 011 & 021 \\
\hline T. humilis & 111 & 101000 & 0322111023 & 1000 & 00100 & 011112 & 10021 \\
\hline T. obliqua & 11 & 210 & 00 ? ? ? ? ? ? 23 & 100 & 00002 & 011 & 021 \\
\hline T. obtusa & 010 & 2010000000 & 0221111023 & 11000 & 00100 & 011111 & 10020 \\
\hline T. opponens & 011 & 3001100 & 0322111223 & 000 & 00100 & 011112 & 021 \\
\hline T. semipellu & 10 & 30001000 & 0221110323 & 011000 & 001000 & 011110 & 10021 \\
\hline Tolania A & 00 & 30001000 & 0322110223 & 011000 & 001000 & 011112 & 021 \\
\hline Tolania B & 01 & 3000100000 & 0321100223 & 011000 & 001000 & 011112 & 10021 \\
\hline Tolania C & 01 & 3000100100 & 0322111223 & 0 ?? 0?? & ?? ?? ?? & ? 11112 & 10021 \\
\hline Tolania D & 01 & 30001000 & 0302110223 & 011000 & 001000 & 011112 & 10021 \\
\hline Tolania E & 01 & 3000100000 & 0322101123 & 1000 & 001001 & 011112 & 10021 \\
\hline & & & 101123 & 1000 & 0011 & $0 ?$ & \\
\hline Tola & 01 & 3000100000 & 101323 & 000 & 001 & $0 ?$ & 10021 \\
\hline & & 0 & 23 & 000 & 0010 & $0 ?$ & 21 \\
\hline Tolania I & 00 & 3000 & 03 & 000 & 0010 & & 10021 \\
\hline Tolania J & & 300 & 23 & 00 & 00 & & 021 \\
\hline Tolania $\mathrm{K}$ & 01 & 3000 & 0322 & 00 & 0010 & 011 & 10021 \\
\hline Tolania L & & 301 & $01 ? ? ? ? ? ? 23$ & 00 & 00 & $0 ?$ & 021 \\
\hline Tolania M & 01 & 3000100000 & 0312101223 & 1000 & 00100 & 011112 & 10021 \\
\hline Tolania N & 01 & 30001 & 0322110223 & 000 & 00100 & 01 & 10021 \\
\hline Tolania O & 1001 & 3000000000 & 0322110223 & 1000 & 00100 & $01111200 ?$ & 10021 \\
\hline Tolania P & 1000 & 3000100000 & 0322110223 & 1000 & 00100 & $01111200 ?$ & 10021 \\
\hline Tolania Q & 01011 & 2000100000 & 0322110223 & 011000 & 00110 & $01111 ? ? 0 ?$ & 10021 \\
\hline Tolania R & 01010 & 3000100000 & 0300110023 & 011000 & 00100000100 & $01111200 ?$ & 10021 \\
\hline Tolania S & 1000 & 3000100100 & 0320110023 & 011000 & 00100000100 & $01111200 ?$ & 10021 \\
\hline Tolania $\mathrm{T}$ & 01000 & 3000100000 & 01 ? ? ? ? ? 23 & 0210011000 & 00100000100 & $01111200 ?$ & 10021 \\
\hline Tolania U & 11001111 & 3000111000 & 0320111023 & 0210011000 & 00100000100 & $01111010 ?$ & 10021 \\
\hline Tolania V & 111000011 & 3001100000 & 0323110023 & 0210011000 & 00100000100 & $01111010 ?$ & 10021 \\
\hline Tolania W & 1111101011 & 3000100000 & 0300110223 & 0210011000 & 10100000100 & $01111200 ?$ & 10021 \\
\hline Tolania X & 1111001011 & 3000100000 & 0322111323 & 0210011000 & 10110000100 & $01111210 ?$ & 10021 \\
\hline Tolania Y & 1111001011 & 3000100000 & 0321111223 & 0210011010 & 10110000100 & $01111210 ?$ & 10021 \\
\hline
\end{tabular}


Appendix 2. Continued.

\begin{tabular}{|c|c|c|c|c|c|c|c|}
\hline & 1 & 1111111112 & 2222222223 & 3333333334 & 4444444445 & 5555555556 & 66666 \\
\hline & 1234567890 & 1234567890 & 1234567890 & 1234567890 & 1234567890 & 1234567890 & 12345 \\
\hline Tolania Z & 111001011 & 3000100000 & 0322101123 & 0210011000 & 1011000010 & $001111210 ?$ & 10021 \\
\hline Tolania AA & 111001011 & 3000100000 & 0322111123 & 210011000 & 1011000010 & $001111210 ?$ & 0021 \\
\hline Tolania BB & 111001011 & 3000100000 & 0322111123 & 0210011000 & 1011000010 & $001111210 ?$ & 10021 \\
\hline Tolania CC & 11001011 & 0100000 & 0312111023 & 0210011000 & 010 & $001111210 ?$ & 10021 \\
\hline Tolania DD & 111000011 & 3000100000 & 0322101323 & 0210011000 & 2010000010 & $001111110 ?$ & 10021 \\
\hline Tolania EE & 111000011 & 3000110000 & 0322111323 & 0210011000 & 2010010010 & $101111210 ?$ & 10021 \\
\hline Tolania FF & 1111000010 & 3000100000 & 0323101323 & 0200011000 & 0010000010 & $001111210 ?$ & 10021 \\
\hline Tolania GG & 111101100 & 3000111100 & 0302000023 & 2210011100 & 0000000010 & $101111210 ?$ & 10021 \\
\hline Tolania $\mathrm{HH}$ & 1111101111 & 3000111100 & 0322000223 & 2210011100 & 0000000010 & $101111220 ?$ & 10021 \\
\hline Tolania II & & 300011 & 0302101223 & 0210011100 & & $101111220 ?$ & 10021 \\
\hline Tolania JJ & 1111101111 & 3000111100 & 01 ?? ?? ?? 23 & 0210011100 & 000030 & $101111110 ?$ & 10020 \\
\hline Tolania KK & & 300010 & 032211 & 02100 & & $101111010 ?$ & 10021 \\
\hline Tolania LL & 11120 & $? 000101100$ & 0211111323 & 0210011000 & 0010000 & $001111210 ?$ & 10021 \\
\hline Tolania MM & & 300 & 0322100323 & 02100 & & $101111110 ?$ & 10021 \\
\hline Tolania NN & 010 & 2011 & 032211 & 0210 & 10 & $001111110 ?$ & 10021 \\
\hline Tolania OO & & 201 & 032211 & & & 0011111 & 10021 \\
\hline Tolania PP & 010 & 201 & 030 & 0210 & 10 & $001111110 ?$ & 10021 \\
\hline Tolania QQ & & 201 & 0202 & 0210 & 10 & 0011111 & 10021 \\
\hline Tolania RR & 010 & 201 & & 0210 & 10 & 0011 & 10020 \\
\hline Tolania SS & & 201 & $? 23$ & 0210 & 10 & 0011 & 10020 \\
\hline Tolania TT & 00010 & 2011000000 & 00 ??????2 3 & 02100 & 10 & 001111 & 10021 \\
\hline Tolanic & & 201 & 020 & 0220 & 10 & 0011 & 10020 \\
\hline Tolania VV & 00010 & 201 & 03021 & 02200 & 10 & 0011 & 10020 \\
\hline Tolania WW & & 301 & 0323 & 02100 & 10 & 0011 & 10021 \\
\hline Tolania XX & 010 & 300 & 023 & 02100 & 10 & 0011 & 10021 \\
\hline Tolania YY & 10 & 3000100000 & 032211 & 0210011 & 10 & 0011 & 10021 \\
\hline Tolania ZZ & 10 & 3000100000 & 03231 & 000 & 10 & 0011 & 021 \\
\hline Tolania AAA & 11000010 & 3000100000 & 0211101223 & 0210011000 & 10 & $001111010 ?$ & 10021 \\
\hline Tolania BBB & & 2001100000 & 0323110 & 0210 & 10 & 0011 & 10021 \\
\hline Tolania CCC & 010 & 2100100100 & 0300110223 & 02101 & 000010 & $001111000 ?$ & 10021 \\
\hline Antillotolania & 03000000 & 0100000001 & $130 ? 110221$ & 02100 & $0 ? 0$ & $000101000 ?$ & 00000 \\
\hline Campylocentrus & 100000010 & 3100000010 & 10 ? ? ? ? ? 11 & 0000000000 & 1020001001 & $101011000 ?$ & 00020 \\
\hline Centronodus & 0100000011 & 1111100210 & 1300100010 & ?0?01????? & ????000000 & $001100000 ?$ & 10010 \\
\hline Deiroderes & 1100100010 & 1001100211 & 11 ?? ?? ? 21 & 0210000000 & $00001001 ? 0$ & $000111 ? 00 ?$ & 10020 \\
\hline Flexocentrus & 0100001010 & 1001100201 & 1300110110 & $00 ? 0000001$ & 0000000000 & $100010000 ?$ & 00010 \\
\hline Microcentrus & 0001101010 & 0000110201 & 1323111213 & $00 ? 0000001$ & 1100000100 & $100011000 ?$ & 10021 \\
\hline Multareoides & 0100000101 & 1000110201 & 1???????00 & ???02????? & ?? ??000000 & $001000000 ?$ & 00010 \\
\hline
\end{tabular}

Continued 
Appendix 2. Continued.

\begin{tabular}{|c|c|c|c|c|c|c|c|}
\hline & & & & 1 & 1111111111 & 1111111111 & 11111 \\
\hline & 66667 & 7777777778 & 8888888889 & 9999999990 & 0000000001 & 1111111112 & 22222 \\
\hline & 67890 & 1234567890 & 1234567890 & 1234567890 & 1234567890 & 1234567890 & 12345 \\
\hline Eudonica nanella & 10100 & 000000000 & 000105001 & 1210010000 & 0000000001 & $0000 ? 03001$ & $00 ? ? ?$ \\
\hline Euwalkeria perdita & 10100 & 000000000 & 1000003000 & 1110010001 & 0000000001 & $0000 ? 0 ? 201$ & $00 ? ? ?$ \\
\hline Euwalkeria colorata & 10100 & 0000000000 & 000001010 & 1110010001 & 0000000001 & $0000 ? 0 ? ? 01$ & 00120 \\
\hline Holdgatiella chiloensis & 00100 & 0000000000 & 1000003000 & 1310010000 & 0000000002 & $0000 ? 03115$ & 00000 \\
\hline Nicomia inscripta & 12021 & $? 010000120$ & $000002000 ?$ & 0210010001 & 0000000001 & $0000 ? 02201$ & 00110 \\
\hline N. buccina & 12021 & 1010000111 & 0000020000 & 0100010000 & 0000000001 & $0000 ? 10201$ & $00 ? ? ?$ \\
\hline N. interrupta & 12021 & 1000000120 & 0100020010 & 0200011100 & 0000000001 & $0000 ? 01001$ & 00120 \\
\hline N. jucunda & 11021 & 1000000110 & 0000020000 & 0200010001 & 0000000000 & ?? ? 0 ? 02200 & 00120 \\
\hline N. monticola & 11020 & 1000000010 & 0000023000 & 1310010001 & 0000000000 & ?? ? 1101201 & $00 ? ? ?$ \\
\hline N. nigrifasciata & 11021 & 0010000011 & 0000020001 & 0300010001 & 0000000000 & ?? ? 1101001 & $00 ? ? ?$ \\
\hline N. notidana & 12021 & 0010000020 & 0000121000 & 1210010000 & 0000000000 & ?? ?0?00000 & $00 ? ? ?$ \\
\hline N. pulchella & 12021 & 0010000010 & 0100023001 & 0210010000 & 0001000000 & ? ? ? 0 ? 02000 & 00110 \\
\hline N. serrata & 11021 & 1010000121 & 0020001 & 0400 & 0000000 & ?? ? 21 & 00120 \\
\hline N. subfasciata & 11020 & 0000000110 & 0000020000 & 1310010001 & 0000000000 & ?? ? 1100001 & 00101 \\
\hline Nodonica bispinigera & 10100 & 0000000000 & & & 000 & $0000 ? 0$ & $00 ? 00$ \\
\hline Stalomia veruta & 10100 & 0000000000 & 100 & 000 & 0000000000 & ? ? ? 0 ? & $00 ? ? ?$ \\
\hline Tolania femoralis & 00120 & 0100010000 & & 01 & 100 & ??011 & 00020 \\
\hline T. fraterna & 10120 & 010001 & 10001 & 001 & 00001 & $0000 ?$ & 01020 \\
\hline T. humilis & 00120 & 000 & 00 & 01 & 000 & ? ? 01 & 00020 \\
\hline T. obliqua & 0110 & 0000 & 100 & 101 & 000 & 010 & $00 ? ? ?$ \\
\hline T. obtusa & 120 & 00 & & 01 & 000 & 000 & 01020 \\
\hline & & 000 & 00 & & 11 & 00 & 20 \\
\hline T. semipellucida & & 02 & & & 10 & 21 & 20 \\
\hline & & 00 & 00 & 00 & 00 & ??? & 020 \\
\hline Tolania B & 00120 & 00 & 00 & & 01 & $00 ?$ & 20 \\
\hline & & & & & 01 & 001 & \\
\hline Tolania D & 00120 & 010001 & 00 & 00 & 02 & 000 & 00000 \\
\hline & & & & & & & 20 \\
\hline Tolania F & 110 & 00 & & & 00 & ??? & 20 \\
\hline Tolania G & & & & & & & \\
\hline Tolar & 120 & 00 & 00 & 00 & 02 & 201 & $000 ? 0$ \\
\hline Tolania I & & 00 & & & 02 & 01 & 00 \\
\hline Tolania J & 120 & 000 & & & 01 & 011 & 000 \\
\hline Tolania $\mathrm{K}$ & 120 & 000 & & & 01 & 010 & 20 \\
\hline Tolania L & 0110 & 0100110000 & 1000 & 000 & 011 & $1000 ? 1$ & $00 ? ? ?$ \\
\hline Tolania M & 0120 & 0000110000 & 3100 & 000 & 00000 & 1010 & 00020 \\
\hline Tolania $\mathrm{N}$ & 0120 & 0000010000 & 000103100 & 000 & 0000000002 & $1010 ?$ & $00 ? ? ?$ \\
\hline Tolania $\mathrm{O}$ & 0110 & 0100010000 & 000101100 & 001 & 0000000001 & $0000 ? 1$ & 00020 \\
\hline Tolania P & 00120 & 0200010000 & 1000101100 & 000 & 0000001001 & $0010 ? 0$ & $00 ? ? ?$ \\
\hline Tolania Q & $? 0120$ & 0000010000 & 1000101100 & 000 & 0000010001 & $0110 ? 1$ & $00 ? ? ?$ \\
\hline Tolania R & $? 0120$ & 0200010000 & 1000101000 & 1310110000 & 0000000001 & $1000 ? 03000$ & 00020 \\
\hline Tolania S & 10120 & 0100010000 & 1000103000 & 1110110000 & 1000010000 & ??00?03004 & $00 ? ? ?$ \\
\hline Tolania $\mathrm{T}$ & 00120 & 0100010000 & 1000123000 & 1110110010 & 0000000001 & $1000 ? 03201$ & 00020 \\
\hline Tolania U & 00120 & 0200010000 & 1000101200 & 1310110000 & 0000000001 & $0100 ? 13004$ & $00 ? ? ?$ \\
\hline Tolania V & 00120 & 0100010000 & 1000101000 & 1310110001 & 0000100001 & $0000 ? 03201$ & 01010 \\
\hline Tolania W & $? 01 ? 0$ & 0000010000 & 1000101100 & 1310210000 & 0000000001 & $0000 ? 03101$ & $00 ? ? ?$ \\
\hline Tolania X & 00120 & 0000010000 & 1000101100 & 1110110000 & 0000000001 & $0000 ? 03201$ & $00 ? ? ?$ \\
\hline Tolania Y & 10120 & 0000010000 & 1000101000 & 1110110000 & 0000020001 & $0010 ? 03221$ & 00020 \\
\hline
\end{tabular}

Revista Brasileira de Zoologia 22 (1): 231-283, março 2005 
Appendix 2. Continued.

\begin{tabular}{|c|c|c|c|c|c|c|c|}
\hline & & & & 1 & 1111111111 & 1111111111 & 11111 \\
\hline & 66667 & 7777777778 & 8888888889 & 9999999990 & 0000000001 & 1111111112 & 22222 \\
\hline & 67890 & 1234567890 & 1234567890 & 1234567890 & 1234567890 & 1234567890 & 12345 \\
\hline$\overline{\text { Tolania Z }}$ & 10120 & 0000010000 & 1000101000 & 1110110000 & 0000000001 & $0000 ? 03310$ & 00020 \\
\hline Tolania AA & 10120 & 0000010000 & 1000101000 & 1110110000 & 0000000001 & $0010 ? 03310$ & 00 ? ?? \\
\hline Tolania BB & 10120 & 0000010000 & 1000101000 & 1110110000 & 0000100001 & $0000 ? 13201$ & 00020 \\
\hline Tolania CC & 10120 & 0000010000 & 1000101000 & 1110110000 & 0000000100 & ???0?03221 & 00020 \\
\hline Tolania DD & 10120 & 0100010000 & 1000101000 & 1410110001 & 0000000011 & $0100 ? 13121$ & 01020 \\
\hline Tolania EE & 10120 & $0 ? 00010000$ & 1000101000 & $1410 ? 10001$ & 0000000011 & $0100 ? 13101$ & 01020 \\
\hline Tolania FF & 10120 & 0000010000 & 1000101100 & 1310110000 & 0000000001 & $1000 ? 03001$ & 00020 \\
\hline Tolania GG & 00110 & 0000010000 & 1000101000 & 1110010000 & 0000000002 & $0000 ? 03035$ & 00020 \\
\hline Tolania $\mathrm{HH}$ & 10110 & 0000010000 & 1000003000 & 1010010000 & 0000000101 & $0010 ? 13115$ & 00020 \\
\hline Tolania II & 10110 & 0000010000 & 1000101100 & 1010010000 & 0000000101 & $0010 ? 03115$ & $00 ? ? ?$ \\
\hline Tolania JJ & 00110 & 0000010000 & 1000101100 & 1010012000 & 0000000001 & $0010 ? 13001$ & $00 ? ? ?$ \\
\hline Tolania KK & 00110 & 0000010000 & 1000001100 & 1110010000 & 0100000001 & $0000 ? 1313 ?$ & 00001 \\
\hline Tolania LL & 00110 & 0100010000 & 1000101000 & 1310110000 & 0010010002 & $0010 ? 03001$ & 00020 \\
\hline Tolania MM & 00110 & 0000010000 & 1000101000 & 10000 & 0000020002 & $0110 ? 03001$ & 00020 \\
\hline Tolania NN & 10120 & 0200010000 & 1112114000 & 10000 & 0000000002 & $2000 ? 14241$ & $01 ? ? ?$ \\
\hline Tolania OO & 10120 & 0200010000 & 1111114000 & 010000 & 0000000002 & $2000 ? 04241$ & $01 ? ? ?$ \\
\hline Tolania PP & & 0200010000 & 1111114000 & & 0000000002 & $2000 ? 04241$ & $01 ? ? ?$ \\
\hline Tolania QQ & 10120 & 0200010000 & 1111114000 & 10000 & 0000000002 & $2000 ? 14241$ & 01020 \\
\hline Tolania RR & & 0100010000 & & & 0000000002 & $1000 ? 04241$ & $01 ? ? ?$ \\
\hline Tolania SS & 10120 & 0000010000 & 1111113000 & 1310110000 & 0000100002 & $2000 ? 04201$ & $01 ? ?$ ? \\
\hline Tolania TT & & 0200010000 & 1102113000 & & 0000000001 & $00 ? 0 ? 14203$ & 01020 \\
\hline Tolania UU & 10120 & 0201112000 & 1100121000 & 1401010001 & 0000100001 & $0000 ? 13002$ & $01 ? ?$ ? \\
\hline Tolania VV & 10120 & 0201112000 & 1100121000 & 1401010001 & 0000000001 & $0000 ? 13002$ & $01 ? ?$ ? \\
\hline Tolania WW & 10120 & 0200112000 & 1100102010 & 1412110000 & 0000000001 & $0000 ? 04201$ & $11 ? ? ?$ \\
\hline Tolania XX & 00120 & 0200012000 & 1000122010 & 1402010000 & 0000000000 & ???2102001 & $00 ? ? ?$ \\
\hline Tolania YY & 00120 & 0200010000 & 1100101010 & $141011 ? 000$ & 0000000010 & ??? 1113021 & 00020 \\
\hline Tolania ZZ & 00120 & 0200010000 & 1100101010 & $141011 ? 000$ & 0000000010 & ??? 1113021 & 00020 \\
\hline Tolania AAA & 10120 & 0100011000 & 1100101010 & $141001 ? 000$ & 0000000010 & ??? 1113021 & 00020 \\
\hline Tolania BBB & 00110 & 0000010000 & 1000003000 & 1110010000 & 0000000101 & $0000 ? 03015$ & $00 ? ? ?$ \\
\hline Tolania CCC & $101 ? 0$ & 0000010000 & 1100103000 & 1110010000 & 0000000000 & ???0? 13001 & $00 ? ? ?$ \\
\hline Antillotolania & 10100 & ? ?0??????? & $1 ? 0000300 ?$ & 0 ??? ? 10000 & 0000000000 & ???0?0? ? 01 & 00001 \\
\hline Campylocentrus & ? $0 ? 21$ & $? 000010000$ & 1100003000 & 1010000000 & 0100000000 & ?? ? 0 ? 03000 & $00 ? 01$ \\
\hline Centronodus & 10100 & 0000010000 & 1000102000 & 1310000000 & 0100000000 & ?? ? 0 ? 03200 & $00 ? 01$ \\
\hline Deiroderes & $? 0100$ & 0000010000 & 1000101000 & 1010000000 & 0000000000 & ?? ? $0 ? 03 ? 00$ & $00 ? 01$ \\
\hline Flexocentrus & 10100 & 0000010000 & 1100003000 & 1310000000 & 0100000000 & ? ? ? 0 ? ? 3030 & $00 ? ? ?$ \\
\hline Microcentrus & 10110 & 0000010000 & 1000102000 & $1 ? 10100000$ & 0100000000 & ?? ? 0 ? 00030 & 00020 \\
\hline Multareoides & $001 ? 1$ & 0010010000 & 1000002000 & $1 ? 10000000$ & 0000000000 & ???2 103030 & $00 ? ? ?$ \\
\hline
\end{tabular}

Received in 01.VI.2004; accepted in 07.III.2005. 